\title{
Gustavo DaHER
}

\section{Polimorfismos nos genes ASMT, AANAT e MTNR1A, que codificam proteínas do sistema melatonina,}

modulam a susceptibilidade a complicações microvasculares em indivíduos com diabete melito tipo 1

Tese apresentada à Faculdade de Medicina da Universidade de São Paulo para obtenção do título de Doutor em Ciências

Programa de Endocrinologia

Orientadora: Prof ${ }^{\mathrm{a}}$. Dr ${ }^{\mathrm{a}}$. Maria Lucia Cardillo Côrrea Giannella

Coorientador: Prof. Dr. José Cipolla Neto

São Paulo 
Dados Internacionais de Catalogação na Publicação (CIP)

Preparada pela Biblioteca da

Faculdade de Medicina da Universidade de São Paulo

Creprodução autorizada pelo autor

\section{Daher, Gustavo}

Polimorfismos nos genes ASMT, AANAT e MTNR1A, que codificam proteínas do sistema melatonina, modulam a susceptibilidade a complicações microvasculares em indivíduos com diabete melito tipo 1 / Gustavo Daher São Paulo, 2021.

Tese(doutorado)--Faculdade de Medicina da Universidade de São Paulo.

Programa de Endocrinologia.

Orientadora: Maria Lucia Cardillo Côrrea Giannella.

Coorientador: José Cipolla Neto.

Descritores: 1.Complicações do diabetes 2.Melatonina 3.Receptor MT1 de melatonina 4.Diabetes mellitus tipo 1 5.Polimorfismo de nucleotídeo único 6.Estresse oxidativo 7.Nefropatias diabéticas 8.Retinopatia diabética 9.Arilalquilamina $\mathrm{N}$-acetiltransferase

USP/FM/DBD-110/21

Responsável: Erinalva da Conceição Batista, CRB-8 6755 
Dedico esta tese à minha mãe Silvia, meu primeiro e mais potente exemplo de profissional e pesquisadora, à minha esposa e companheira de vida Carol pelo amor infinito e apoio incondicional em todos os momentos de vida e às minhas filhas Isabela e Helena que diariamente me tornam uma pessoa melhor. 
Aos pacientes, que são a motivação deste projeto e que, com suas doações de materiais e dados, foram vitais para sua execução.

Agradeço à minha orientadora, Profa. Dra. Maria Lúcia Cardillo Corrêa Giannella a quem carinhosamente e costumeiramente chamamos de Malu. Gostaria de lhe agradecer por esses quase 10 anos de convivência, iniciando em minha residência médica, passando pela preceptoria e certamente com o ápice ao longo da execução deste projeto. Jornada com muitas fases e dificuldades, mas certamente sua orientação tornou tudo mais fácil. Obrigado por apoiar a possibilidade de fazer algo tão diferente do dia a dia do LIM. Obrigado por me mostrar que estávamos, sim, no caminho certo e pelo fato de sempre parecer que o doutorado estava "quase pronto". Obrigado pela compreensão com relação aos meus horários caóticos e inseguranças com relação aos resultados. Obrigado por enxergar em mim um potencial pesquisador. Obrigado, sobretudo, pelos ensinamentos e pela amizade ao longo desses anos.

Agradeço ao meu coorientador, Prof. Dr. José Cipolla-Neto, que acolheu nosso projeto quando este era apenas uma ideia e, com seu conhecimento inesgotável sobre melatonina, enxergou seu potencial, incluindo este à sua linha de projetos temáticos. Muito obrigado pelas diversas reuniões no ICB e infinitos e-mails. Tenho certeza de que aprendi muito nestas trocas.

À minha amiga e "orientadora informal" Daniele Pereira dos Santos Bezerra. Desde o primeiro dia em que comecei a delinear como seriam as coletas desde projeto, você me apoiou e meu dicas sem as quais seria impossível ter chegado até aqui. Obrigado pelas "aulas" em todos os temas possíveis envolvendo a elaboração de uma tese de doutorado. Obrigado também pelas risadas e pelo bom humor constante!

Ao Thiago Patente que, mesmo distante fisicamente, sempre se mostrou disponível para dúvidas variadas em estatística e seus segredos. 
À amiga Sharon Admoni que, desde minha residência, vem sendo um exemplo de competência e simplicidade e que sempre tem a palavra e conselho certo nos dias complicados.

Agradeço a todos os Malunos que me precederam, compartilharam esta jornada comigo e que me auxiliaram diretamente neste trabalho com dados, tabelas, conselhos e dicas; e indiretamente garantindo boas risadas! Obrigado Ricardo Perez, Marcos Tadashi, Juliana Zucare, Tatiana Pelaes, Sharon Admoni, Karina Thieme, Beatriz Monteiro e Thiago Patente.

Aos funcionários do LIM-25, em especial à Ana Mercedes, que me apoiou imensamente com toda parte técnica e experimentos que viabilizaram esta pesquisa.

À Dra. Fernanda Amaral, que desde a fase de concepção do projeto se disponibilizou a ajudar efetivamente na sua execução. Muito obrigado pelo apoio técnico na realização dos experimentos e pelas diversas discussões, que certamente foram fundamentais para a conclusão deste projeto.

Aos colegas de Pós-graduação e membros dos laboratórios do ICB-USP e Laboratório de Neurobiologia da Pineal da UNIFESP, que apoiaram a realização das análises técnicas dos metabólitos da melatonina.

À Profa. Dra. Maria Adelaide que, para mim, sempre foi e segue sendo uma referência na medicina e endocrinologia e que me incentivou após a preceptoria a me aventurar no doutorado. Meu muito obrigado pelo apoio e por se manter uma constante fonte de inspiração para uma geração de endocrinologistas.

À Profa. Dra. Marcia Nery e à Profa. Dra. Marcia Queiroz que sempre me incentivaram a me aprofundar no campo do Diabetes e por me ensinarem tanto ao longo de tantos anos.

Ao amigo Dr. Carlos André Minanni, que vem construindo carreira paralela à minha e que, constantemente, me ajudou a equilibrar todos as obrigações, fornecendo dicas e me ajudando em inúmeras tarefas. 
Aos membros do Grupo de Diabetes, Residentes e Preceptores da Disciplina de Endocrinologia, que apoiaram no recrutamento dos pacientes.

A todos os funcionários, enfermeiras e auxiliares de enfermagem que contribuíram para a coleta de amostras.

Aos voluntários do grupo controle, que cederam material para que pudesse realizar este trabalho.

Aos diversos colegas do Hospital Israelita Albert Einstein que apoiaram a realização deste doutorado. Em especial agradeço ao Dr. José Maluf pelo estímulo inicial; à Dra. Raquel Conceição, por me apoiar na jornada; às amigas Enf. Thalita Modena e Cristiane Seko, pelo apoio na captação de controles saudáveis e ao Rafael Dadão, pelas dicas inestimáveis no Excel.

Ao meu pai Eduardo que, em toda minha formação como pessoa e estudante, me apoiou sem questionamentos pelas minhas escolhas, me dando asas para que conseguisse perseguir meus sonhos.

À minha mãe Silvia, que certamente me transmitiu o "gene" da pesquisa. Sem saber, ao longo de minha vida ao vê-la batalhando pela publicação de artigos e na rotina de uma pesquisadora brasileira me incentivou, mesmo sem querer, a embarcar nesta aventura. Obrigado mãe, por sempre me ajudar na vida e neste projeto, afinal não é pouca coisa ter uma mãe orientadora!

Às minhas três motivações de viver, Carol, Isabela e Helena.

À Carol, minha esposa e parceira de vida e de todas as horas, a quem agradeço diariamente por me fazer uma pessoa melhor, por me incentivar nos dias em que minha energia se vai, por estar ao meu lado nas conquistas e por me apresentar cotidianamente o real significado de companheirismo, parceria e amor. Meu amor ,meu muito obrigado!

Às minhas maiores conquistas da vida, Isabela e Helena, que nasceram no decorrer deste projeto e que me mostram cada dia, especialmente em tempos difíceis como os que estamos vivendo hoje, que nenhuma força do mundo é maior que o amor sincero e incondicional que tenho por vocês. 
À FAPESP, pelo financiamento do projeto, sob a coordenação do Prof. Dr. José Cipolla-Neto. Em tempos sombrios como os atuais, muito me orgulha conseguir concluir este trabalho, de algum modo reforçando que a ciência sempre prevalecerá. 
Essa tese está de acordo com as seguintes normas em vigor no momento dessa publicação:

Referências: adaptado do International Commitee of Medical Jornals Editors (Vancouver).

Universidade de São Paulo, Faculdade de Medicina, Divisão de Biblioteca e Documentação. Guia de apresentação de dissertações, teses e monografias. Elaborado por Anneliese Carneiro da Cunha, Maria Julia de A. L. Fredd, Maria F. Crestana, Marinalva de Sousa Aração, Suely Campos Cardoso, Valeria Vilhena. 3a Ed. São Paulo. Divisão de Biblioteca e Documentação, 2011.

Abreviação dos títulos dos periódicos de acordo com o List of Journals Indexed in Index Medicus. 


\section{SUMÁRIO}

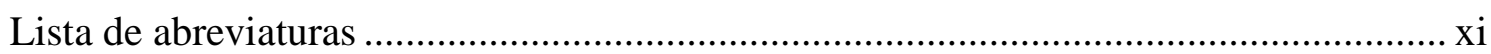

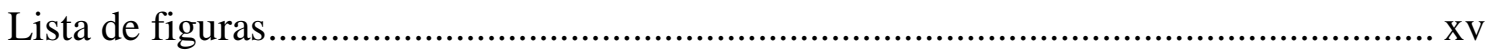

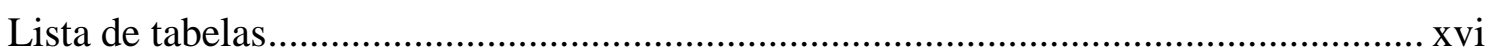

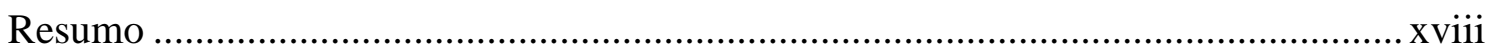

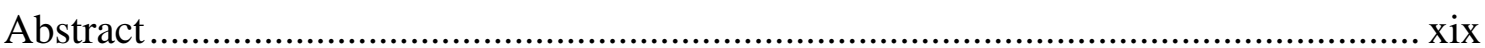

1 INTRODUÇÃ

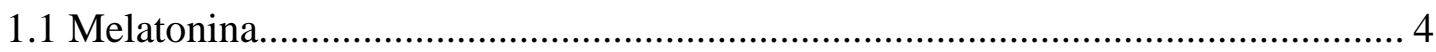

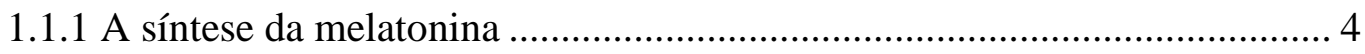

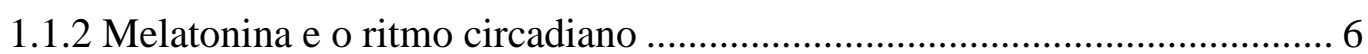

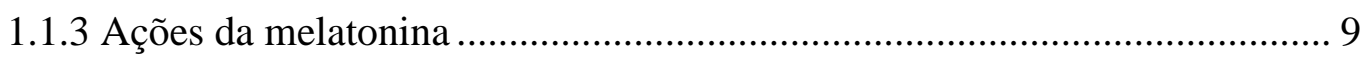

1.1.4 Melatonina e metabolismo da glicose .................................................. 12

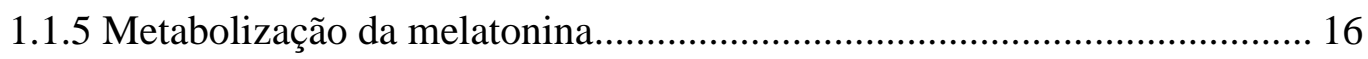

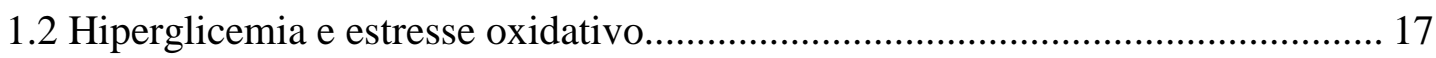

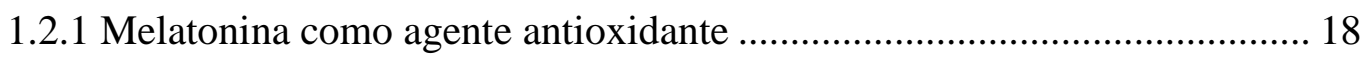

1.2.2 Redução na síntese de melatonina como consequência do DM................. 21

1.2.3 Polimorfismos em genes relacionados à síntese e ação da melatonina...... 23

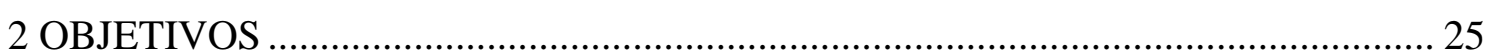

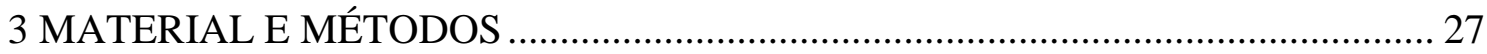

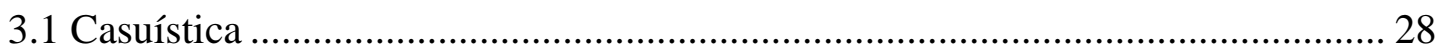

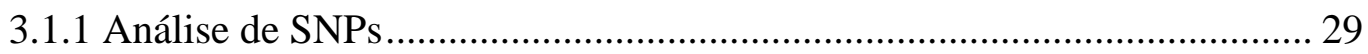

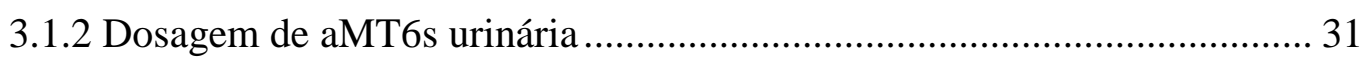

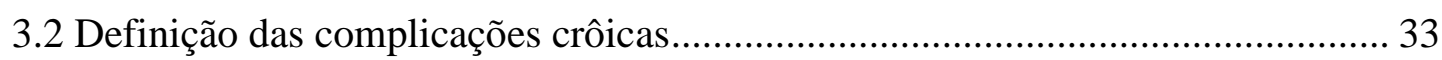

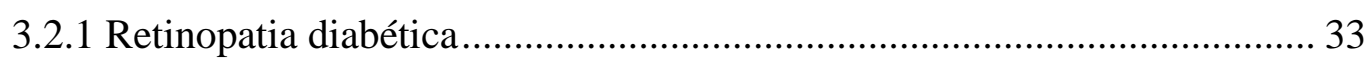

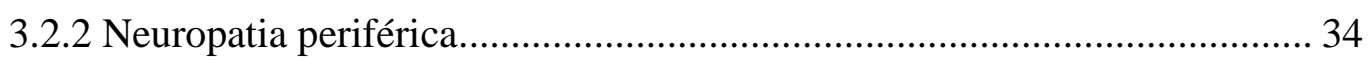

3.2.3 Neuropatia autonômica cardiovascular .................................................. 34

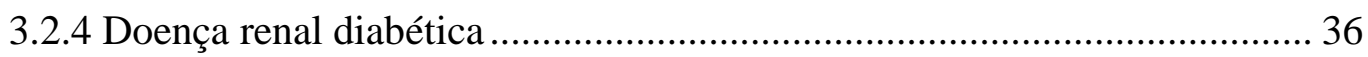

3.2.5 Decaimento da função renal............................................................. 37

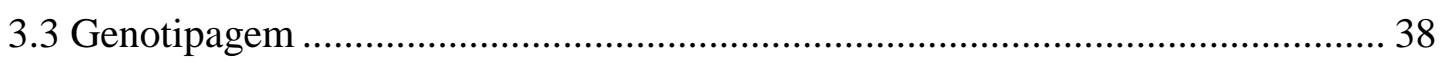

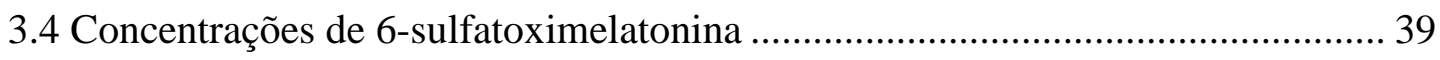

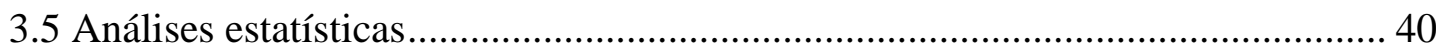




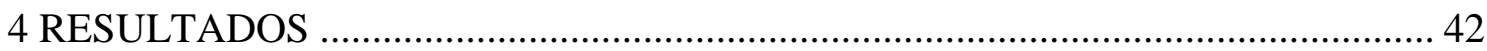

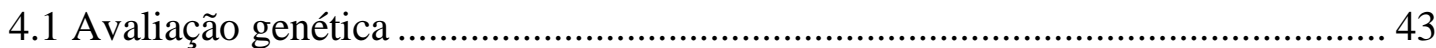

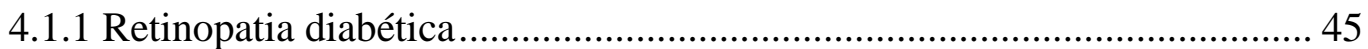

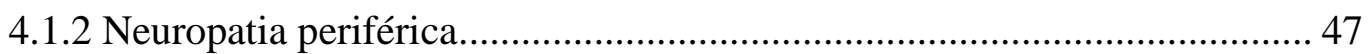

4.1.3 Neuropatia autonômica cardiovascular .................................................. 49

4.1.4 Doença renal diabética .......................................................................... 51

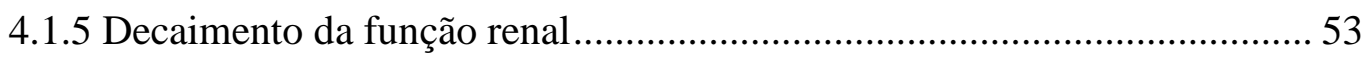

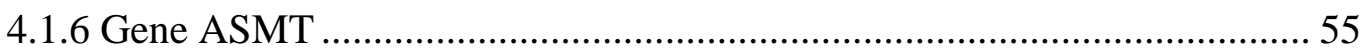

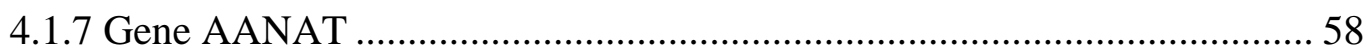

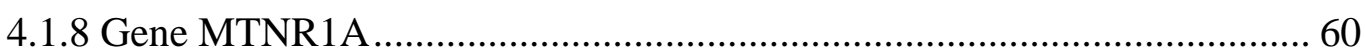

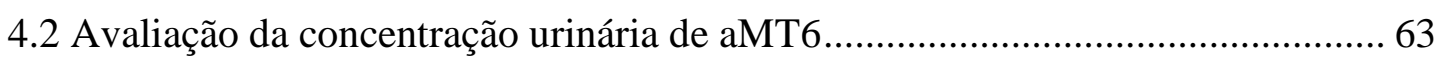

4.2.1 Concentração de melatonina urinária e análise genética ........................... 70

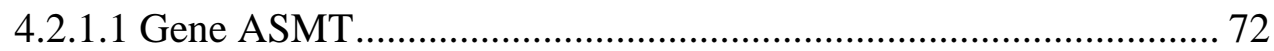

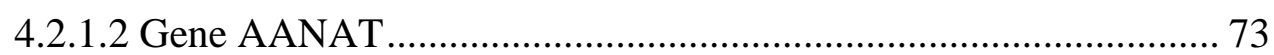

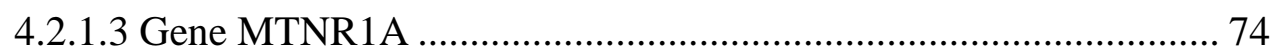

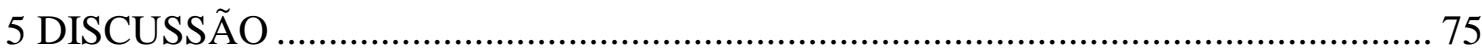

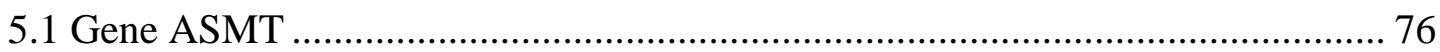

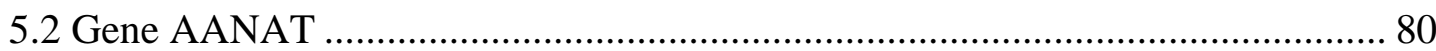

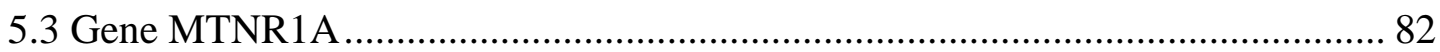

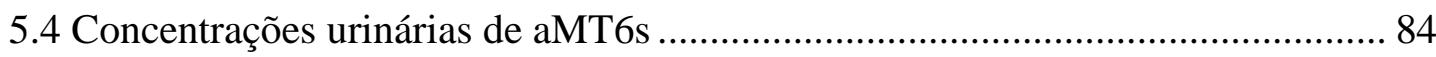

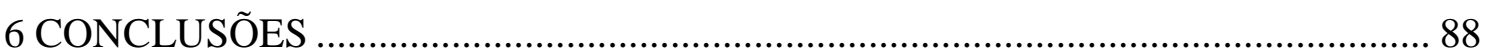

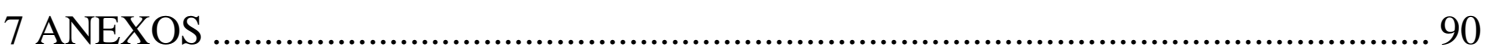

Anexo 1 - Parecer Consubstanciado do CEP …….................................................. 91

Anexo 2 - Termo de Consentimento Livre e Esclarecido ........................................... 94

Anexo 3 - Escala de Sonolência de Eppworth (ESS-BR) ........................................ 99

Anexo 4 - Questionário do Sono ......................................................................... 104

Anexo 5 - Gene ASMT, Gene AANAT, Gene MTNR1A...................................... 107

Anexo 6 - Análise genética e concentração de aMT6s urinária............................... 119

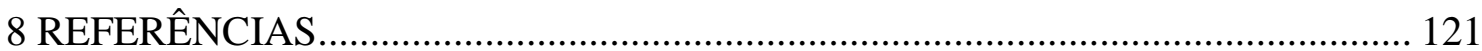




\section{ABREVIATURAS}

5-HT Serotonina (5-hidroxitriptamina)

AANAT Enzima arilalquilamina $\mathrm{N}$-acetiltransferase

ACR Razão de albumina/creatinina urinária (do inglês: albumin creatinine ratio)

AFMK N1-acetil-N2-formil-5-metroxiquinuramina

AMK N-acetil-5-metroxiquinuramina

AMPc Adenosina monofosfato cíclico

aMT6s 6-sulfatoximelatonina urinária

ATP Adenosina trifosfato

ASMT Enzima acetilserotonina-metiltransferase

BRA Bloqueadores do receptor de angiotensina II

cDNA DNA complementar

CCGs Clock controlled genes

CKD-EPI Chronic kidney disease epidemiology collaboration

CYP1A2 Do inglês: Cytochrome P450 family 1 subfamily A member 2

DAC Doença arterial coronariana

DCV Doença cardiovascular

DM Diabetes mellitus

DM1 Diabetes mellitus tipo 1

DM2 Diabetes mellitus tipo 2 


\begin{tabular}{|c|c|}
\hline DNA & Ácido desoxirribonucleico \\
\hline DNMTs & DNA metiltransferases \\
\hline dNTPs & Desoxinucleosídeos trifosfato \\
\hline DRCT & Doença renal crônica terminal \\
\hline DRD & Doença renal diabética \\
\hline dUTP & Desoxiuridina trifosfato \\
\hline EAU & Excreção de albumina urinária \\
\hline EDTA & $\begin{array}{l}\text { Ácido etilenodiamino tetra-acético (do inglês: Ethylenediamine } \\
\text { tetraacetic acid) }\end{array}$ \\
\hline ELISA & $\begin{array}{l}\text { Ensaio de imunoabsorção (do inglês: Enzyme-linked } \\
\text { immunosorbent assay) }\end{array}$ \\
\hline EHW & Equilíbrio de Hardy-Weinberg \\
\hline $\mathrm{FC}$ & Frequência cardíaca \\
\hline GSH & Glutationa \\
\hline HAS & Hipertensão arterial sistêmica \\
\hline $\mathrm{HbA1c}$ & Hemoglobina glicada \\
\hline HC-FMUSP & $\begin{array}{l}\text { Hospital das Clínicas da Faculdade de Medicina da Universidade } \\
\text { de São Paulo }\end{array}$ \\
\hline HIOMT & Enzima hidroxindol-O-metiltransferase \\
\hline HDL-c & Lipoproteína de alta densidade (do inglês: high-density lipoprotein) \\
\hline $\mathrm{HF}$ & Alta frequência (do inglês: high frequency) \\
\hline $\mathrm{HO}_{2}^{-}$ & Radical hidroperoxila \\
\hline HPLC & $\begin{array}{l}\text { Cromatografia líquida de alta performance (do inglês: high- } \\
\text { performance liquid chromatography) }\end{array}$ \\
\hline IC & Intervalo de confiança \\
\hline IECA & Inibidor da enzima conversora da angiotensina \\
\hline IMC & Índice de massa corpórea \\
\hline IRC & Insuficiência renal crônica \\
\hline
\end{tabular}


IRMAs Anormalidades microvasculares intrarretinianas (do inglês: intraretinal microvascular abnormality)

ISRS Inibidores seletivos de receptação de serotonina

$\mathrm{OH}^{-\quad \text { Radical hidroxil }}$

LDL Lipoproteína de baixa densidade (do inglês: low-density lipoprotein)

LF Baixa frequência (do inglês: low frequency)

MAF Frequência do alelo raro (do inglês: minor allele frequency )

MT1 Receptor de Melatonina do tipo 1

MT2 Receptor de Melatonina do tipo 2

MTNR1A Gene que codifica o receptor de melatonina do tipo 1

MTNR1B Gene que codifica o receptor de melatonina do tipo 2

NAC Neuropatia autonômica cardiovascular

NAS 5-acetilserotonina (do inglês: $N$-Acetylserotonin)

NADPH Nicotinamida adenina difosfato (do inglês: nicotinamide adenine dinucleotide phosphate)

NGSP-EUA National Glyco Hemoglobin Standardization Program - Estados Unidos da América

NP Neuropatia periférica

$\mathrm{O}_{2}^{-} \quad$ Radical superóxido

OMS Organização Mundial de Saúde

OR Odds ratio

PCR Reação em cadeia da polimerase (do inglês: polymerase chain reaction)

PKA Proteína cinase A

RD Retinopatia diabética

RDNP Retinopatia diabética não proliferativa

RDP Retinopatia diabética proliferativa 
ROS Espécies reativas de oxigênio (do inglês: reactive oxygen species)

RNA Ácido ribonucléico

RNS Espécies reativas de nitrogênio (do inglês: reactive nitrogen species)

SIRT1 Sirtuína 1

SNPs Polimorfismos de um único nucleotídeo (do inglês: single nucleotide polymorphisms)

SOD Enzima superóxido dismutase

SRAA Sistema renina-angiotensina-aldosterona

TCLE Termo de consentimento livre e esclarecido

TFGe Taxa de filtração glomerular estimada

TG Triglicérides

USP Universidade de São Paulo

VFC Variabilidade de frequência cardíaca

VLF Frequência muito baixa (do inglês: very low frequency)

$\chi^{2} \quad$ Teste do qui-quadrado 


\section{FIGURAS}

Figura 1 - Coleta de dados de indivíduos participantes do estudo de análise

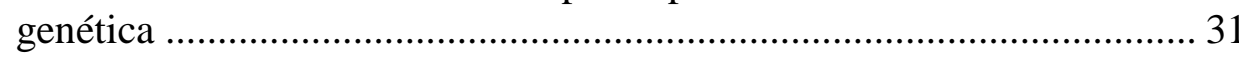

Figura 2 - Coleta de dados de indivíduos participantes do estudo de concentração de aMT6s

Figura 3 - Concentrações de aMT6s urinária de acordo com a presença ou ausência de alelo raro A no rs4446909 do gene ASMT (modelo codominante).

Figura 4 - Concentração de 6-sulfatoximelatonina urinária (ng/mg) de acordo com a presença do haplótipo CACAGGAA dos polimorfismos avaliados no gene MTNRIA. 


\section{TABELAS}

Tabela 1 - Polimorfismos de um único nucleotídeo (SNPs) nos genes ASMT, AANAT e MTNR1A caracterizados quanto ao Equilíbrio de Hardy-Weinberg (EHW) e quanto à frequência do alelo raro (MAF)

Tabela 2 - Características demográficas, clínicas e laboratoriais mais recentes da população de indivíduos com diabete melito tipo 1 avaliada.

Tabela 3 - Características demográficas, clínicas e laboratoriais mais recentes da população de indivíduos com diabete melito tipo 1 classificada de acordo com a ausência ou presença de retinopatia diabética (RD) .... 46

Tabela 4 - Características demográficas, clínicas e laboratoriais mais recentes da população de indivíduos com diabete melito tipo 1 classificada de acordo com a ausência ou presença de neuropatia periférica (NP)

Tabela 5 - Características demográficas, clínicas e laboratoriais mais recentes da população de indivíduos com diabete melito tipo 1 classificada de acordo com a ausência ou presença de neuropatia autonômica cardiovascular (NAC)

Tabela 6 - Características demográficas, clínicas e laboratoriais mais recentes da população de indivíduos com diabete melito tipo 1 classificada de acordo com a ausência ou presença de doença renal diabética (DRD).

Tabela 7 - Características demográficas, clínicas e laboratoriais basais da população de indivíduos com diabete melito tipo 1 classificada de acordo com a velocidade de declínio da taxa de filtração glomerular estimada.

Tabela 8 - Frequência dos genótipos dos polimorfismos nos genes ASMT de acordo com a ausência ou presença de retinopatia diabética (RD)

Tabela 9 - Frequência do haplótipo AA do gene ASMT de acordo com o status do declínio da função renal.

Tabela 10 - Frequência do haplótipo GGGCCGGCC de acordo com o status com a ausência ou presença de retinopatia diabética (RD)

Tabela 11 - Frequência do haplótipo GGGATCGCC de acordo com o status com a ausência ou presença de neuropatia autonômica cardiovascular (NAC) 
Tabela 12 - Frequência dos haplótipos GGCACCGTT e TGGATCGCC de acordo com o status do declínio da função renal

Tabela 13 - Frequência dos genótipos dos polimorfismos no gene MT1 de acordo com o status do declínio da função renal).....

Tabela 14 - Frequência do haplótipo CACAGGAA de acordo com a ausência ou presença de doença renal diabética (DRD) e com o status do declínio da função renal

Tabela 15 - Características demográficas, clínicas e laboratoriais mais recentes dos indivíduos com diabete melito tipo 1 que coletaram urina para a dosagem da aMT6

Tabela 16 - Comparação das características demográficas, clínicas e de sono dos indivíduos com diabete melito tipo 1 (DM1) e dos indivíduos controle sem DM1 que coletaram urina para a dosagem da aMT6.

Tabela 17 - Concentrações de aMT6s urinária corrigidas pela creatinina dos indivíduos com diabete melito tipo 1 (DM1) e dos indivíduos controle sem DM1 que coletaram urina para a dosagem da aMT6 66

Tabela 18 - Características demográficas, clínicas e laboratoriais dos indivíduos com diabete melito tipo 1 apresentando concentrações de aMT6 urinária acima ou abaixo da mediana

Tabela 19 - Concentrações de aMT6s urinária corrigida pela creatinina dos indivíduos com diabete melito tipo 1 agrupados de acordo com o status das complicações crônicas avaliadas

Tabela 20 - Características demográficas, clínicas e laboratoriais dos indivíduos com diabete melito tipo 1 que coletaram urina para a dosagem da aMT6 e material genético. 


\section{RESUMO}

Daher G. Polimorfismos nos genes ASMT, AANAT e MTNRIA, que codificam proteínas do sistema melatonina, modulam a susceptibilidade a complicações microvasculares em indivíduos com diabete melito tipo 1 [tese]. São Paulo: Faculdade de Medicina, Universidade de São Paulo; 2021.

INTRODUÇÃO: Já está bem estabelecido o papel crítico do estresse oxidativo resultante da hiperglicemia na etiopatogenia das complicações crônicas do diabete melito (DM), juntamente com a hipertensão arterial sistêmica, a dislipidemia e uma suscetibilidade genética. Diversos estudos demonstram a participação da melatonina no metabolismo da glicose, bem como seu importante papel como antioxidante endógeno. Polimorfismos genéticos podem alterar a produção e a ação da melatonina. $\mathrm{O}$ presente estudo teve por objetivos avaliar (1) se o risco de complicações crônicas microvasculares em indivíduos com DM tipo 1 (DM1) está associado com polimorfismos de um único nucleotídeo (SNPs) em genes que codificam enzimas responsáveis pela síntese da melatonina (ASMT e AANAT) e o receptor MT1 da melatonina (MTNRIA) e (2) a associação entre as concentrações urinárias do principal metabólito da melatonina, a 6-sulfatoximelatonina (aMT6s), a as complicações microvasculares. MÉTODO: Dados demográficos, clínicos e laboratoriais foram coletados de 489 indivíduos com DM1 com mais de 10 anos de doença; urina para a dosagem de aMT6s foi coletada de 94 indivíduos com DM1 e de 30 controles sem DM. A genotipagem de SNPs nos genes ASMT, AANAT e MTNRIA foi realizada por reação em cadeia da polimerase em tempo real nos 489 indivíduos. As seguintes complicações foram avaliadas: retinopatia diabética (RD), doença renal diabética, neuropatia periférica e neuropatia autonômica cardiovascular, além do decaimento da função renal. RESULTADOS: A presença do alelo A no SNP rs4446909 no gene ASMT, que codifica a enzima acetilserotonina-metiltransferase/hidroxindol-O-metiltransferase e é uma das limitantes na produção de melatonina, associou-se a menor risco de RD. Os haplótipos GGCACCGTT e TGGATCGCC no gene AANAT, que codifica outra enzima limitadora da produção de melatonina, associaram-se, respectivamente, a maior e menor risco de declínio da função renal. Na avaliação do gene $M T N R 1 A$, que codifica o receptor de melatonina MT1, a presença do alelo raro A do rs4862705 associou-se a um maior risco para o declínio da função renal no período de seguimento do estudo. Finalmente, na população avaliada, as concentrações de aMT6s urinária foram maiores nos indivíduos com DM1 em relação àqueles sem DM1, mas não se observaram diferenças significantes entre indivíduos com DM1 com e sem qualquer uma das complicações crônicas avaliadas. CONCLUSÕES: SNPs em genes que codificam receptores de melatonina e enzimas da síntese hormonal modularam a susceptibilidade a complicações microvasculares na população estudada.

Descritores: Complicações do diabetes; Melatonina; Receptor MTl de melatonina; Diabetes mellitus tipo 1; Polimorfismo de nucleotídeo único; Estresse oxidativo; Nefropatias diabéticas; Retinopatia diabética; Arilalquilamina N-acetiltransferase. 


\section{ABSTRACT}

Daher G. Polymorphisms in the genes ASMT, AANAT and MTRN1A, which encode proteins of the melatonin system, modulate susceptibility to microvascular complications in Type 1 Diabetes individuals.[thesis]. São Paulo: "Faculdade de Medicina, Universidade de São Paulo"; 2021.

INTRODUCTION: It is already well described the critical role of oxidative stress induced by hyperglycemia in the etiopathogenesis of diabetes mellitus (DM) complications, alongside with systemic hypertension, dyslipidemia and genetic susceptibility. Several studies demonstrated that melatonin influences glucose metabolism, besides being a powerful antioxidant compound. Genetic polymorphisms can alter melatonin production and action The aim of the present study was to explore (1) the association of diabetes microvascular chronic complications in a cohort of type 1 diabetes individuals with single nucleotide polymorphisms (SNPs) in the genes encoding melatonin receptor 1 (MT1, MTNR1A) and the enzymes responsible for melatonin synthesis (ASMT and AANAT) and (2) the association of urinary concentration of melatonin's main metabolite, 6-sulfatoxymelatonin (aMT6s), and microvascular complications. METHOD: Demographic, clinical and laboratorial data were collected from 489 individuals with type 1 diabetes for more than 10 years; urinary samples for aMT6s were collected from 94 individuals with T1D and 30 individuals without DM. SNPs in the genes ASMT, AANAT and MTNRIA were genotyped in the 489 individuals by real-time polymerase chain reaction. The following complications were evaluated: diabetic kidney disease, diabetic retinopathy, distal polyneuropathy, cardiovascular autonomic neuropathy and renal function decline. RESULTS: In the ASMT gene, responsible for encoding ASMT, an enzyme directly involved with melatonin production, a higher frequency of allele A of rs4446909 was associated with a lower risk of presenting diabetic retinopathy. The haplotypes GGCACCGTT and TGGATCGCC in the AANAT gene, responsible for other important enzyme on melatonin synthesis, were respective associated with a higher and a lower risk of decline in renal function during the observational time of this study. In the MTNRIA gene, responsible for encoding MT1 receptor, a higher frequency of A allele of rs4862705 was observed in those presenting a renal function decline > 5 $\mathrm{mL} / \mathrm{min} / 1.73 \mathrm{~m}^{2}$ per year in comparison to non-decliners. Finally, on the population selected to this study, aMT6s urinary concentration was higher in individuals with T1D in comparison to the control group and no differences of aMT6s concentration were observed when evaluating T1D individual according to chronic complications status. CONCLUSION: SNPs in genes that encode melatonin receptor and enzymes responsible for melatonin synthesis modulate susceptibility to microvascular complication in the studied population.

Descriptors: Diabetes complications; Melatonin; Receptor, Melatonin, MT1; Diabetes mellitus type 1; Polimorphism, Single nucleotide; Oxidative stress; Diabetic nephropathies; Diabetic retinopathy; Arylalkylamine N-acetyltransferase. 


\section{INTRODUÇÃO}

Atualmente, o diabete melito (DM) é uma das principais causas de amaurose, insuficiência renal crônica e neuropatias debilitantes na população mundial ${ }^{(1)}$. Estas complicações possuem etiopatogenia comum, e se caracterizam pela presença da microangiopatia relacionada à hiperglicemia. Uma das estratégias para redução na frequência dessas complicações é o controle intensivo do DM, porém, este está associado ao aumento do número de hipoglicemias ${ }^{(2,3)}$. Além do controle glicêmico e pressórico adequados, a literatura reconhece, porém não define claramente, a presença de fortes preditores para o desenvolvimento das complicações do DM e, embora o bom controle glicêmico seja o objetivo para todos os indivíduos com DM, a identificação daqueles indivíduos com maior susceptibilidade para desenvolvimento das complicações poderia direcionar e otimizar o tratamento intensivo nesses indivíduos ${ }^{(3)}$.

Diversos marcadores genéticos já foram avaliados com o objetivo de identificar indivíduos sob maior risco. Visando a identificação de genes candidatos, duas principais estratégias de exploração do genoma humano são atualmente utilizadas: a primeira utiliza o mapeamento de genes baseado em sua posição no genoma, sendo denominada rastreamento genômico (genome scan). A segunda estratégia parte da fisiopatologia da doença em questão e busca investigar os genes envolvidos em vias biológicas específicas que se associam com essa fisiopatologia.

Apenas $0,1 \%$ da sequência do genoma difere entre os seres humanos e grande parte dessas diferenças relaciona-se a polimorfismos, que são variações do genoma presentes em mais de $1 \%$ da população total. Dentre os polimorfismos, a troca, inserção 
ou deleção de um único nucleotídeo no DNA é a forma mais comum, sendo essas alterações denominadas SNPs (single nucleotide polymorphisms) ${ }^{(4)}$.

A predisposição às doenças poligênicas é determinada por esses polimorfismos, alguns dos quais são funcionais, sendo assim descritos por serem capazes de influenciar a expressão gênica, alterando a quantidade final da proteína codificada por aquele gene $^{(5)}$.

Inúmeros estudos demonstram que fatores genéticos estão envolvidos na susceptibilidade para o desenvolvimento das complicações microvasculares no DM tipo 1 (DM1). Neste sentido, genes relacionados a mecanismos de regulação da glicemia já foram investigados, uma vez que a hiperglicemia é parte fundamental da gênese dessas complicações. De maneira similar, tendo claro que o estresse oxidativo tem papel central na fisiopatologia dessas complicações, genes que codificam enzimas que interferem nos diferentes mecanismos anti- e pró-oxidantes são candidatos a conferirem susceptibilidade, ou proteção, contra as complicações crônicas ${ }^{(6-11)}$.

Estudos prévios mostram o papel da melatonina como importante elemento regulador do metabolismo glicídico, modulando a síntese e ação da insulina de acordo com o ritmo circadiano ${ }^{(12)}$. Além disto, este hormônio também age, de maneira direta e indireta, na regulação do estresse oxidativo, bem como em vias que se relacionam a este desequilíbrio ${ }^{(13-16)}$. Desta maneira, o estudo de variantes genéticas que possam interferir na síntese ou ação da melatonina, além da concentração hormonal encontrada em indivíduos com DM, pode apresentar-se como dado relevante para a maior compreensão e consequente prevenção de complicações relacionadas ao DM. 


\subsection{MELATONINA}

Isolada e descrita em 1958, a melatonina teve inicialmente reconhecidas suas propriedades de agregar grânulos de melanina nos melanócitos, o que deu origem a seu nome ${ }^{(17)}$. Ao longo dos últimos 60 anos, está molécula foi reconhecida como hormônio, produzido pela glândula pineal, e como tal, destacando-se como principal mediador dos fenômenos cíclicos ambientais para o organismo. Consequentemente, aprofundou-se o conhecimento quanto a interação da melatonina com diferentes processos fisiológicos, tais como regulação endócrina e metabólica, regulação dos ciclos atividade-repouso e sono-vigília e regulação do sistema imunológico ${ }^{(12)}$.

Atualmente, estudos utilizando técnicas de biologia molecular e a pesquisa com anticorpos de alta sensibilidade identificaram a presença de melatonina em praticamente todos os órgãos e tecidos do corpo humano pesquisados, sendo descritas para essa melatonina de produção local, exclusivamente ações parácrinas e autócrinas ${ }^{(18)}$.

\subsubsection{A síntese da Melatonina}

A melatonina é uma indolamina, usando como substrato inicial o aminoácido triptofano. O triptofano transforma-se em 5-hidroxitriptofano pela ação da enzima triptofano-hidroxilase (TPH1), sendo na sequência convertido à serotonina (5-HT) após a descaboxilação de um aminoácido aromático. A 5-HT é, então, acetilada, transformando-se em 5-acetilserotonina (NAS) por meio da atuação da enzima arilalquilamina $\mathrm{N}$-acetiltransferase (AANAT), uma das enzimas limitantes do processo da síntese hormonal. A NAS, por sua vez, é convertida em melatonina após a 
oximetilação mediada pela acetilserotonina-metiltransferase/hidroxindol-Ometiltransferase (ASMT, previamente conhecida como HIOMT) ${ }^{(19)}$.

A síntese da melatonina pineal é realizada por células endócrinas chamadas pinealócitos, presentes na glândula pineal, que está, por sua vez, localizada entre as comissuras posterior e habenular, na parte mais dorsal e posterior do terceiro ventrículo cerebral, chamada de recesso pineal ${ }^{(20)}$.

O controle da síntese de melatonina na glândula pineal resulta de um processo complexo que envolve diferentes elementos do sistema nervoso central. O núcleo paraventricular hipotalâmico se projeta, através de conexões diretas e indiretas com os neurônios pré-ganglionares simpáticos da coluna intermédio-lateral da medula torácica alta que, por sua vez, se projetam sobre os gânglios cervicais superiores. Os axônio dos neurônios pós-ganglionares destes gânglios, através dos ramos carotídeos internos e nervos conários, inervam a glândula pineal ${ }^{(21)}$.

Na glândula pineal, a norepinefrina ativa receptores $\beta 1$ e $\alpha 1$, que estimulam a atividade enzimática intracelular. Entre os diferentes mecanismos ativados, destaca-se o aumento da síntese e/ou ativação de AANAT, que quando presente em maior concentração ou quando está mais ativa, acaba promovendo aumento na produção de melatonina pelos pinealócitos ${ }^{(22,23)}$.

Ressalta-se que, uma vez sintetizada, a melatonina não é armazenada, sendo liberada para circulação, onde liga-se à albumina. Parte do hormônio produzido é liberada diretamente no líquor, interagindo diretamente com o sistema nervoso central $^{(24)}$.

Além da produção de melatonina pela glândula pineal, diversos estudos identificaram a presença das enzimas relacionadas ao processo da síntese de melatonina 
(ASMT, AANAT) em diferentes tecidos, tais como a própria retina, o trato gastrointestinal, a pele, as células do sistema imunológico, o pâncreas etc. Em alguns destes sítios, estudos demonstraram a presença de melatonina, sugerindo produção local deste hormônio ${ }^{(20)}$.

Estes diferentes tecidos produzem quantidade muito inferior a produzida na glândula pineal e, aparentemente, a ação da melatonina de origem extra-pineal é apenas no tecido local, sem ação sistêmica. Essa melatonina de origem não pineal, por meio de ações autócrinas ou parácrinas, além da regular fenômenos fisiológicos celulares locais, pode exercer uma ação antioxidante, graças às características físico-químicas dos carbôneos 2 e 3 do anel pirrólico da molécula da melatonina. É importante destacar também que a produção extra-pineal, com exceção da produção por células da retina, ocorre sem relação direta com o estímulo foto-luminoso, sugerindo a presença de outros fatores de regulação da sua síntese ${ }^{(18,21,25)}$.

\subsubsection{Melatonina e o ritmo circadiano}

A síntese e secreção de melatonina na glândula pineal são temporizadas circadianamente pelas projeções dos núcleos supraquiasmáticos hipotalâmicos (considerado o relógio biológico circadiano) que, por sua vez, é sincronizado ao ciclo claro/escuro por projeções retino-hipotâlamicas dos axônios das células ganglionares retinianas intrinsicamente fotossensíveis. Deste modo, a produção de melatonina pineal é circadiana e tem seu pico de secreção no momento da noite/escuridão, não havendo produção durante o dia ${ }^{(11)}$.

Complementarmente, a presença de luz, mesmo no período da noite, dependendo de sua intensidade e comprimento de onda, é capaz de bloquear completa e 
instantaneamente a produção de melatonina, fazendo com que sua concentração plasmática caia a valores basais em poucos minutos. Esse efeito também é mediado por células retinianas que, ao interagirem com o sistema hipotalâmico, acabam por inibir a projeção simpática para a glândula pineal e, consequentemente, todos os mecanismos já descritos essenciais para a produção de melatonina. Deste modo, sua presença no organismo é quase indetectável ao longo de momentos do dia/claridade, não só pela ritmicidade diária de sua produção, como também, pela foto-inibição exercida pela luz do dia ${ }^{(26)}$.

Dado o fato de que boa parte da síntese de melatonina (e de seus componentes) depende desta sincronização, a concentração extracelular do hormônio também se relaciona com a duração do período escuro (escotoperíodo) e da alternância dia e noite (ou claro e escuro). Assim, o perfil plasmático da melatonina também varia de acordo com as noites mais longas ou mais curtas típicas das diversas estações do ano ${ }^{(27)}$.

Baseando-se nos dados descritos, atualmente reconhece-se que a glândula pineal, por meio da melatonina (e seus diferentes perfis de produção), possui o papel fisiológico de sinalizar para o organismo se é noite ou dia no meio exterior e, pela duração da secreção hormonal, sinalizar em qual estação do ano estamos. Logo, entende-se que a melatonina representa a principal expressão biológica da variação fotoperiódica circadiana e sazonal, sendo também reconhecida como a expressão biológica da noite $^{(12,27)}$.

O ritmo circadiano é definido sucintamente como um processo de interação entre fatores ambientais (principalmente luminosidade e temperatura) e processos biológicos que se alternam em um ritmo cíclico conhecido de aproximadamente 24 horas ${ }^{(28)}$. A ritmicidade circadiana humana é ditada primariamente por um sistema de genes 
chamados genes relógio, ou clock genes, que regulam a expressão de um grupo de genes controlados por esses clock genes, conhecidos como clock controlled genes (CCGs), que transcrevem proteínas de maneira rítmica. Essas atuam nos neurônios do chamado relógio biológico circadiano (núcleo supraquiasmático hipotalâmico, como mencionado acima) que, por sua vez, é o responsável por sincronizar o restante do organismo de maneira direta, pela comunicação neural ao sistema nervoso autônomo e suas derivações, ou de maneira indireta, por meio da liberação hormonal, por exemplo. Além disto, atualmente reconhece-se que as células periféricas e demais neurônios são também osciladores ou relógios periféricos, mantendo sua ritmicidade justamente pela expressão rítmica de proteínas transcritas pelos clock genes e pelos CCGs, juntamente com a interação com o relógio biológico central ${ }^{(29,30)}$.

Este complexo sistema, essencialmente autônomo, sofre influência de fatores reguladores externos conhecidos como zeitgebers. A melatonina, justamente por ser o representante interior do fotoperíodo externo, apresenta-se como um importante zeitgeber para o meio interno, sendo capaz de atuar na expressão dos clock genes e dos CCGs, e na transcrição e degradação das proteínas responsáveis por sincronizar esses genes tanto nas estruturas do relógio biológico circadiano, quanto em outras estruturas do sistema nervoso central e em células periféricas. Consequentemente, a melatonina apresenta-se como grande moduladora do ritmo circadiano e das diferentes funções fisiológicas a ele ligadas ${ }^{(29-31)}$.

Assim, por meio de suas ações direta ou indiretas, a melatonina interage com diferentes estruturas e órgãos periféricos, desencadeando mecanismos adaptativos e processos fisiológicos, metabólicos e comportamentais adequados para a noite ou para dia e para as diferentes estações do ano. Ela é considerada o elemento unificador na 
sincronização dos diferentes níveis de controle circadiano e circanual ou sazonal (células, tecidos, órgãos e sistemas fisiológicos) ${ }^{(32)}$.

\subsubsection{Ações da melatonina}

As diferentes ações da melatonina no organismo podem ocorrer por ação direta do hormônio, não mediada por receptores, nos diferentes tecidos ou por sua interação com receptores específicos.

As ações diretas, ou não mediadas, ocorrem justamente como resultado da interação direta da melatonina com outras moléculas, especialmente no ambiente intracelular. É importante ressaltar que bioquimicamente, pela presença dos grupamentos acetil e metoxi e pelo grupo indol em sua composição, a melatonina é uma substância hidrossolúvel e lipossolúvel, o que confere grande permeabilidade junto às diferentes membranas celulares e de organelas, capacitando-a como uma molécula capaz de atingir diretamente quase todos os compartimentos dos organismos, inclusive sistemas funcionais subcelulares, como a mitocôndria ${ }^{(33)}$.

Dentre as ações diretas mais bem definidas destaca-se a capacidade da melatonina de interagir diretamente (ou indiretamente, por meio do aumento da expressão e atividade das enzimas antioxidantes) com espécies ativas de oxigênio, caracterizando o efeito antioxidante da melatonina, descrito mais detalhadamente à frente.

As ações mediadas dependem de receptores hormonais específicos; são descritos dois receptores celulares específicos localizados na membrana plasmática intitulados MT1 (antigamente descrito como MTNR1A) e MT2 (antigamente descrito como MTNR1B). Ambos são receptores de sete alças ligados a proteína G localizados 
principalmente no sistema nervoso central, em diferentes áreas, como núcleo supraquiasmático, núcleo paraventricular hipotalâmico e pars tuberalis. Estes receptores também são encontrados em diferentes tecidos periféricos, incluindo células $\alpha$ e $\beta$ pancreáticas, adipócitos, hepatócitos e células musculares ${ }^{(34,35)}$.

Além de serem definidos quanto a sua via de ação (direta ou indireta) os efeitos da melatonina podem ser caracterizados, de maneira singular, como imediatos ou prospectivos (também chamados de tardios ou prolongados).

Os efeitos imediatos ocorrem enquanto a melatonina está presente na circulação durante a noite e depende da sua interação com os seus diferentes aceptores moleculares. Sumariamente, esse mecanismo é similar ao de qualquer outro hormônio que, quando secretado, promove alterações em diferentes sítios devido a sua interação com receptores próprios ${ }^{(12)}$.

Já os chamados efeitos prospectivos ou tardios são uma forma de ação específica da melatonina, na qual a presença e ação do composto no período noturno desencadeia mecanismos celulares e moleculares que determinam ações dependentes de respostas celulares que acontecerão quando justamente não existe mais a presença da molécula circulante. Essas ações, portanto, dependem de a melatonina ser produzida de forma rítmica, estando presente de noite e ausente de dia. De maneira simplificada, os efeitos prospectivos podem ser subdivididos em efeitos proximais (ou consecutivos) e efeitos distantes (ou prolongados) ${ }^{(12)}$.

Os efeitos prospectivos proximais são os que se iniciam quase que imediatamente após a diminuição da concentração plasmática de melatonina. Esses efeitos ocorrem justamente na transição do período escuro para o claro. Pode se observar isto estudando-se a relação entre as diferentes concentrações hormonais e o 
funcionamento das vias de transdução intracelular. Como exemplo, temos que a ligação da melatonina ao receptor MT1 inibe a cascata da adenilciclase (por efeito imediato), porém imediatamente após a diminuição na concentração hormonal circulante, essa mesma cascata passa por um processo de up-regulation que tem sua intensidade relacionada justamente ao tempo em que esta mesma cascata ficou inibida pela melatonina. Este movimento de up-regulation da via da adenilciclase resulta em ações intracelulares com diferentes consequências e que têm seu tempo de ação atrelado justamente à duração da inibição inicial promovida pela melatonina, que ocorreu na noite anterior. Assim, caracteriza-se um efeito da melatonina que ocorre após sua eliminação (ou redução) no sistema ${ }^{(36)}$.

Já os efeitos prospectivos distais dependem da expressão rítmica dos clock genes e dos CCGs, bem como das ações decorrentes destas expressões. Resumidamente, a melatonina durante à noite, enquanto está presente na circulação, regula (de modo positivo ou negativo) a expressão dos clock genes celulares. Esses genes formam um sistema complexo de transdução e tradução gênicas que dura aproximadamente 24 horas; suas proteínas regulam a expressão dos chamados CCGs, que nada mais são que os genes funcionais das células. Ou seja, a melatonina noturna, agindo de forma imediata,e a sua retirada da circulação ao fim da noite, regulam a expressão de genes que vão, em última instância, regular a função celular ao longo do dia e da noite ${ }^{(30,37)}$.

Além desses efeitos imediatos e tardios (consecutivos e prolongados), a melatonina, dadas as suas características de produção ligada ao fotoperíodo externo e contraste dia/noite, funciona como um poderoso agente sincronizador da ritmicidade circadiana, regulando a função e ritmicidade do relógio circadiano e, diretamente das células periféricas e centrais. Esse efeito da melatonina é chamado de cronobiótico ${ }^{(12)}$. 
É imprescindível considerarmos as variadas formas de ação temporal (imediata, prospectiva proximal e cronobiótica) e a via pela qual essa ação ocorre, se direta ou indireta, para compreendermos todas os potenciais efeitos deste hormônio. Por ter uma forma de ação tão complexa e interativa, a melatonina é considerada um grande elemento "integrador" de inúmeros processos fisiológicos, sendo que suas diferentes funções ainda estão sendo estudadas e descobertas ${ }^{(12)}$.

\subsubsection{Melatonina e metabolismo da glicose}

A relação entre melatonina e insulina, bem como a interação entre esses hormônios no metabolismo glicídico, é ainda alvo de diversos estudos. Modelos animais mostraram a presença de receptores de insulina em pinealócitos e a modulação exercida por diferentes concentrações de insulina sobre a síntese de melatonina ${ }^{(38,39)}$. De modo similar, estudos demonstram a relação entre diferentes concentrações de melatonina e sua ritmicidade e a síntese e ação da insulina ${ }^{(40,41)}$.

Considerando-se apenas a ação imediata da melatonina no pâncreas que ocorre no período em que o hormônio está disponível, este atua nas células pancreáticas via receptores MT1 e MT2.

A ligação da melatonina aos receptores MT1 ativa a proteína G inibitória, que inativa a via da adenilciclase celular e, consequentemente, reduz as concentrações de adenosina monofosfato cíclico (AMPc) celular e a ativação da proteína cinase A (PKA). Especificamente na célula $\beta$ pancreática, a interação entre as concentrações de AMPc, cálcio e adenosina trifosfato (ATP) traduz-se em redução na secreção de insulina. A ação da melatonina através dos receptores MT2 também ativa a proteína G inibitória, reduzindo a secreção de insulina ${ }^{(42)}$. 
Alternativamente, estudos demonstraram que receptores MT1 em células pancreáticas humanas também ativam uma via alternativa ligada a proteína Gq/11. Esta, quando estimulada, ativa a fosfolipase C e libera inositol 1,4,5-trifosfato (IP3), que promove mudanças nas concentrações de cálcio intracelular, resultando em liberação de insulina ${ }^{(43)}$.

Por fim, estudos in vitro e in vivo em seres humanos demonstraram a presença de receptores MT2 também em células $\alpha$ pancreáticas (em modelos animais, há evidências da presença de receptores MT1 e MT2). A aparente ação (novamente imediata) da melatonina sobre essas células é de estímulo à síntese e secreção do glucagon. Um estudo demonstrou que células $\alpha$ pancreáticas incubadas em meio rico em melatonina apresentaram maior expressão e secreção de glucagon, especialmente em meio com altas concentrações de glicose, sugerindo uma modulação direta da melatonina sobre as células $\alpha^{(44)}$.

Complementarmente, um estudo experimental que administrou melatonina agudamente a mulheres saudáveis no período da manhã (9h) e noite (21h) com realização posterior de teste de tolerância oral à glicose demonstrou, agudamente, um aumento da resistência à insulina em ambos os horários de administração ${ }^{(45)}$.

Assim, considerando apenas os efeitos imediatos da melatonina, a ação do hormônio (presente no período noturno-escuridão) é a de diminuir a secreção de insulina e aumentar a resistência a esse hormônio pelo estímulo à síntese de glucagon, diminuindo a tolerância à glicose ${ }^{(42)}$, efeito desejado por ser um período em que espécies diurnas, como a humana, estão em jejum.

Contudo, é imprescindível considerar que a melatonina também atua de maneira prospectiva, seja proximal ou de maneira prolongada, além da ação cronobiótica. Deve- 
se considerar, ainda, que a flutuação circadiana e circanual participa na variação diária e sazonal esperada do metabolismo glicêmico. Durante o dia, quando há menor secreção de melatonina, há uma maior sensibilidade central e periférica à insulina, maior tolerância à glicose, maior secreção de insulina, maior glicólise hepática e muscular, maior síntese de glicogênio e lipogênese e maiores concentrações de adiponectina. Em contrapartida, na fase do sono/escuro, quando a secreção de melatonina é maior, há menor aporte energético e maior consumo das reservas, aumento de gliconeogênese e glicogenólise hepática, da lipólise e da secreção de leptina, além de resistência à insulina ${ }^{(13)}$.

Sendo o ser humano um animal diurno, a ciclicidade descrita acima, do ponto de vista fisiológico, pode ser entendida da seguinte maneira: no momento de maior atividade (e portanto, ingesta alimentar e maior gasto de energia) há uma adaptação circadiana promovendo maior ativação metabólica (maior tolerância à glicose); enquanto que no momento do repouso - à noite- o organismo se adapta, reduzindo a ingesta alimentar e o dispêndio energético pela menor ativação deste sistema (resistência insulínica) ${ }^{(12)}$

Animais pinealectomizados e que, portanto, tem seu ritmo circadiano alterado, desenvolvem maior resistência à insulina e apresentam modificações em seu metabolismo energético com consequente aumento de massa corpórea. Adicionalmente, já foi demonstrado que a reposição de melatonina de maneira cíclica nestes mesmos animais é capaz de reverter tais alterações $(41,46,47)$.

Da mesma forma, estudos em humanos, realizados em indivíduos com redução das concentrações de melatonina por diferentes causas, como em trabalhadores noturnos ou aqueles com alta exposição à iluminação artificial induzida, desenvolvem perfil 
similar de resistência à insulina e intolerância à glicose quando comparados à população geral $^{(48,49)}$.

Um grande estudo de coorte populacional observou relação entre o desenvolvimento de DM tipo 2 (DM2) e uma menor secreção de 6-sulfatoximelatonina urinária, sugerindo que a diminuição de melatonina seja um fator de risco para o desenvolvimento de DM2 ${ }^{(50)}$. Um outro estudo realizado em condições específicas de ciclo sono-vigília em homens adultos demonstrou que indivíduos com DM2 apresentavam ritmo de melatonina plasmática de menor amplitude comparado aos controles sem DM2, reforçando a hipótese aventada ${ }^{(51)}$.

De modo mais específico, tanto em animais quanto em seres humanos, estudos demonstraram que variantes genéticas específicas nos receptores MT2 que alteram a ação da melatonina associam-se à redução na concentração de insulina e aumento na glicemia, conferindo aos portadores dessas variantes maior risco de desenvolvimento de DM2 ${ }^{(52-54)}$. Adicionalmente, estudos recentes mostram a importância da melatonina no trofismo e remodelação plástica do pâncreas endócrino. Assim, um estudo in vitro que promoveu ativação do receptor MT2 por melatonina mostrou redução na perda de células $\beta$ pancreática e em sua disfunção ${ }^{(55)}$; em estudos com animais de experimentação demonstrou-se a importância fundamental da melatonina para a ocorrência das adaptações plásticas das ilhotas pancreáticas e da função das células B pancreáticas necessárias as modificações metabólicas ligadas à gestação e lactação ${ }^{(56)}$.

Levando-se em conta estudos experimentais e estudos populacionais com maior período de seguimento, observa-se que alterações contínuas na secreção ou ação de melatonina (seja por fatores endógenos ou exógenos) com consequente mudança na ciclicidade hormonal, cursam com alterações na ritmicidade de secreção de insulina e na 
sua capacidade de atuação. Portanto, ao invés de existir uma maior secreção e sensibilidade à insulina, o que seria esperado considerando apenas a ação hormonal imediata, a perda dos efeitos tardios e cronobióticos se impõe. Isso sugere que as ações hormonais rítmicas da melatonina, avaliadas no conjunto dos seus efeitos (efeitos imediatos seguidos de efeitos tardios, assim como seu efeito sincronizador circadiano) mostram a relevância desse hormônio para regular as variações diárias da sensibilidade insulínica, absolutamente necessárias para as esperadas adaptações metabólicas ligadas aos períodos de repouso, sono e jejum (resistência insulínica) e atividade, ingesta alimentar, construção dos estoques energéticos (sensibilidade insulínica) ${ }^{(13)}$.

\subsubsection{Metabolização da Melatonina}

A meia vida da melatonina sistêmica é de aproximadamente 45 a 60 minutos. Após sua atuação em diferentes sítios, o hormônio passa a ser metabolizado por diferentes órgãos, como o fígado, rins e o sistema nervoso central. A maior parte da metabolização da melatonina ocorre no fígado, em um processo em que a melatonina é convertida a 6-hidroximelatonina, em sua maior parte pela enzima CYP1A2 (pertencente à família do citocromo P450). Na sequência, a 6-hidroximelatonina é majoritariamente conjugada a um grupo sulfato, originando o composto 6sulfatoximelatonina (aMT6s), sendo uma pequena parcela conjugada com glicoronídeos. Finalmente, ambos os metabólitos são excretados pelos rins e estão presentes na urina ${ }^{(24,57,58)}$.

Uma parte da melatonina é metabolizada diretamente no sistema nervoso central, onde a molécula, após interação com espécies reativas de oxigênio, é transformada em 
N1-acetil-N2-formil-5-metroxiquinuramina (AFMK), que é posteriormente metabolizada à $\mathrm{N}$ - acetil-5-metroxiquinuramina $(\mathrm{AMK})^{(24)}$.

Assim como a síntese hormonal, a metabolização e excreção da melatonina e de seu principal metabólito, a aMT6s, ocorre atrelada ao ritmo circadiano, com pico na fase de escuridão/noite. Diversos estudos já demonstraram que as concentrações urinárias de aMT6s no período noturno e início da manhã correlacionam-se significantemente com as concentrações séricas de melatonina em amostras coletada ao longo do período noturno, sendo um método mais prático e viável para a mensuração das concentrações de melatonina no organismo ${ }^{(59,60)}$.

\subsection{HIPERGLICEMIA E ESTRESSE OXIDATIVO}

O estresse oxidativo é o resultado de alterações entre os mecanismos intracelulares antioxidantes que passam a ser insuficientes para detoxificar um conjunto de moléculas denominadas espécies reativas de oxigênio (reactive oxygen species, ROS), e/ou quando há produção excessiva de ROS independente dos mecanismos antioxidantes ${ }^{(61)}$.

A formação de ROS é algo frequente e usual no metabolismo aeróbico, no qual o oxigênio é reduzido à água. Neste processo fisiológico, há formação de pequena parcela de produtos intermediários incluindo: o radical superóxido $\left(0_{2}{ }^{-}\right)$, o radical hidroperoxila $\left(\mathrm{HO}_{2}{ }^{-}\right)$e o radical hidroxil $(\mathrm{OH})$; esses compostos contam com a presença de um elétron não pareado capaz de reagir com moléculas de DNA, proteínas e lipídios, sendo que cada radical tem mecanismo de ação específico. Assim, sumariamente, os ROS são descritos como compostos extremamente reativos e de meia-vida curta ${ }^{(62)}$. 
De modo a minimizar os efeitos deletérios dos ROS, o organismo possui sistemas enzimáticos e não-enzimáticos que atuam sobre esses compostos; são sistemas complexos, tais como as enzimas superóxido dismutase (SOD), catalase, peroxidase e os sistemas glutationa (GSH), tiorredoxina e glutarredoxina. Além disso, estudos demonstram o papel anti-oxidante exercido também por macromoléculas, como a albumina e a ceruloplasmina e por moléculas pequenas, como as vitaminas $\mathrm{C}$ e $\mathrm{E}$, betacaroteno e ácido úrico ${ }^{(63,64)}$.

A hiperglicemia é reconhecidamente um estado que induz a maior formação de ROS, especialmente nas mitocôndrias, nas quais o excesso de glicose inibe a transferência de elétrons nas reações em cadeia, resultando em íons disponíveis que acabam se ligando a molécula de oxigênio ${ }^{(2)}$. Consequentemente, marcadores de estresse oxidativo estão alterados em indivíduos com DM ${ }^{(61)}$, seja DM1 ${ }^{(65)}$ ou $\mathrm{DM} 2^{(66)}$.

Quatro vias bioquímicas estão classicamente envolvidas na gênese dos danos celulares induzidos pela hiperglicemia: aumento da formação de produtos finais de glicação avançada, aumento da ativação das vias dos polióis, da proteína cinase $\mathrm{C}$ e da via da hexosamina. O estresse oxidativo é considerado o elemento unificador dessas quatro vias bioquímicas implicadas na patogênese das complicações crônicas do $\mathrm{DM}^{(3,67)}$.

\subsubsection{Melatonina como agente antioxidante}

Evolutivamente supõe-se que a origem da melatonina esteja ligada a bactérias fotossintéticas, nas quais seu papel seria justamente o de neutralizar os ROS. Diversos estudos in vitro e in vivo demonstram a capacidade antioxidante da melatonina, seja por 
ações diretas ou indiretas, bem como uma diminuição de reações inflamatórias decorrentes do estresse oxidativo ${ }^{(15,68)}$.

Sabe-se que a melatonina e alguns de seus metabólitos, em específico o AFMK e AMK, possuem efeito "scavenger" direto, neutralizando ROS e espécies reativas de nitrogênio (RNS), reduzindo a peroxidação de lípides e ativando enzimas de reparo do DNA $^{(69)}$.

Pesquisas realizadas com modelos animais estudados em situações ambientais que sabidamente induzem a um aumento do estresse oxidativo, tais como privação alimentar, atividade física forçada ou temperaturas ambientais baixas, mostraram que nestas situações a produção noturna de melatonina aumenta, sugerindo uma produção compensatória ao possível excesso de ROS futuro e, portanto, reforçando sua importância como agente antioxidante ${ }^{(16)}$.

Uma característica benéfica para a atuação da melatonina como antioxidante direto é sua natureza anfifílica (lipofílica e hidrofílica), permitindo, dessa forma, sua livre passagem por diferentes barreiras fisiológicas, o que possibilita sua distribuição e atuação nas fases aquosas e lipídicas, onde se distribuem os diferentes $\operatorname{ROS}{ }^{(33)}$.

Também são descritas ações indiretas da melatonina sobre os demais sistemas antioxidantes, modulando enzimas que atuam para eliminação de ROS ou suprimindo sua produção ${ }^{(68,70)}$. A melatonina interage com o sistema da GSH, aumentando sua produção intracelular e otimizando sua ação pelo estímulo à glutationa redutase, enzima responsável pela regeneração da GSH oxidada em GSH reduzida (forma capaz de exercer ações antioxidantes) ${ }^{(71)}$.

Outro potencial efeito antioxidante da melatonina deriva de sua capacidade de interagir com metais como ferro, cobre e outros, que são potenciais pró-oxidantes. 
Estudos demonstram a capacidade da melatonina para quelar estes metais, contribuindo desta maneira para a redução da formação de $\operatorname{ROS}^{(72,73)}$.

Por reunir tais características, a melatonina é tida como um dos mais potentes antioxidantes; uma molécula de melatonina é capaz de neutralizar até 10 moléculas de ROS, enquanto antioxidantes clássicos (como vitamina C, vitamina E e GSH) normalmente neutralizam um ROS ou menos por molécula ${ }^{(16)}$. As altas concentrações (independentes das concentrações séricas) e as ações da melatonina sobre a mitocôndria são marcantes e se relacionam diretamente com proteção contra mutações e deleções no DNA mitocondrial, podendo ser considerada, inclusive, como o principal antioxidante mitocondrial $^{(68)}$.

Alguns estudos in vivo demonstraram que a suplementação de melatonina reduz as concentrações de diferentes ROS em situações como estresse agudo por cirurgias ${ }^{(74)}$, quadros agudos de infecção, estresse respiratório em neonatos ${ }^{(75,76)}$ e até em condições crônicas, como na doença de Alzheimer, com proteção das células neuronais contra o dano gerado por $\operatorname{ROS}{ }^{(77,78)}$. O potencial anti-inflamatório secundário à capacidade antioxidante da melatonina também já foi demonstrado em indivíduos com infarto agudo do miocárdio e com sepse ${ }^{(79,80)}$.

Além disto, doenças que tem origem na disfunção mitocondrial parecem ser ainda mais beneficiadas pela suplementação de melatonina, tais como esclerose múltipla e distrofia de Duchene, nas quais estudos in vivo demonstraram evolução mais lenta das doenças ou até melhora de alguns sintomas ${ }^{(81,82)}$.

Estudos avaliando a melatonina como antioxidante e sua atuação nas complicações diabéticas estão em curso; em modelos animais, sugere-se que maiores concentrações de melatonina (incluindo reposição) relacionam-se com menores 
concentrações de ROS e menor progressão da retinopatia e da doença renal diabética ${ }^{(83-88)}$, além de potencial de proteção no desenvolvimento de miocardiopatia diabética ${ }^{(89)}$.

\subsubsection{Redução na síntese de melatonina como consequência do DM}

Roedores com DM induzido por estreptozotocina produzem menos melatonina quando comparados ao período antes da indução do DM e também quando comparados a roedores do grupo controle. Parte significante desta redução parece derivar da diminuição da atividade da enzima sódio-potássio-ATPase, que limita a atividade da AANAT, ocasionando menor síntese hormonal. Adicionalmente, ocorre uma redução na expressão dos receptores $\beta 1$ e consequente diminuição na sinalização adrenérgica necessária para desencadear a síntese de melatonina ${ }^{(90)}$.

Nesse mesmo estudo, demonstrou-se que o controle glicêmico obtido com infusão de insulina nos animais foi capaz de readequar as concentrações de melatonina e a atividade da AANAT, sugerindo que o descontrole glicêmico atue diretamente sobre a concentração de melatonina, reduzindo-a e, consequentemente, sua capacidade antioxidante $^{(90)}$.

Outros trabalhos utilizando modelos animais fortalecem a relação entre hiperglicemia e alterações na síntese e concentração de melatonina. Especificamente, um estudo envolvendo roedores com DM2 (Goto Kakizaki) demonstrou uma relação entre hiperglicemia e redução na secreção de melatonina ${ }^{(38)}$. Outro estudo demonstrou, no mesmo modelo animal, aumento na inibição de receptores adrenocorticais e no volume total da glândula pineal ${ }^{(91)}$. 
Indiretamente avaliou-se uma redução na produção de melatonina por meio da análise da concentração urinária de aMT6s em indivíduos com DM1 quando comparados a um grupo controle. Neste estudo, dentre os indivíduos portadores de DM, quanto maior o resultado da glicemia capilar aferida, menor foi a concentração de aMT6s ${ }^{(90)}$. Outro estudo observacional realizado em crianças e adolescentes com DM1 também mostrou menor concentração sérica de melatonina em comparação ao grupo controle sem DM1 ${ }^{(92)}$.

A associação entre complicações crônicas do DM e concentrações de melatonina ainda é pouco explorada na literatura. Um estudo realizado com um grupo pequeno de indivíduos com DM2 com e sem retinopatia diabética e 16 indivíduos sem DM mostrou concentrações significantemente menores de aMT6s urinária no grupo com retinopatia proliferativa em comparação aos demais, porém não se encontrou diferença significante entre os demais grupos ${ }^{(93)}$. Resultados semelhantes foram observadas em um estudo anterior que avaliou as concentrações de melatonina sérica das $0 \mathrm{~h}$ às $3 \mathrm{~h}$ e evidenciou menores concentrações de melatonina em indivíduos com DM2 com retinopatia diabética proliferativa em comparação a indivíduos com DM2 sem retinopatia proliferativa e indivíduos sem DM ${ }^{(94)}$.

Kalere e cols. avaliaram 26 indivíduos com DM2 e obesidade e não encontraram relação significante entre concentrações de melatonina salivar e valores de hemoglobina glicada, tempo de DM ou uso de insulina. No entanto, concentrações menores de melatonina foram observadas nos indivíduos portadores de retinopatia quanto comparado aos não portadores. Esse estudo não observou diferenças nas concentrações de melatonina relacionadas às demais complicações microvasculares ${ }^{(95)}$. 
Finalmente, outro estudo com casuística de 36 indivíduos com DM2 mostrou menores concentrações séricas de melatonina coletada no período da noite na presença de neuropatia autonômica cardiovascular (NAC), mas não das demais complicações. Esse estudo também não encontrou diferenças na calcificação da glândula pineal avaliada radiologicamente ${ }^{(96)}$.

\subsubsection{Polimorfismos em genes relacionados à síntese e ação da melatonina}

As principais enzimas moduladoras da síntese de melatonina são a AANAT e a ASMT. O gene responsável pela síntese da enzima AANAT está localizado no cromossomo 17q25 (97) e SNPs neste gene já foram associados com depressão (rs3760138, rs4238969, rs8150), autismo e aumento de risco de câncer de mama $\left(\right.$ rs3760138, rs8150 e rs4238989) ${ }^{(98-100)}$.

Já o gene que codifica a enzima ASMT está localizado na região pseudoautossômica dos cromossomos X e Y e o SNP rs4446909 desse gene já foi estudado quanto a sua associação com autismo, transtorno afetivo bipolar e depressão, entre outros ${ }^{(101-105)}$.

Os receptores MT1 e MT2 são codificados por genes localizados, respectivamente, nos cromossomos 4q35.1 (MTNR1A) e 11q21-q22 (MTNR1B). SNPs no receptor MT2 já foram relacionados a um aumento no risco de desenvolvimento de glicemia de jejum alterada, DM2 e DM gestacional, especialmente as variantes rs10830963 e rs1387153 ${ }^{(52,53,106-109)}$. Esses e outros SNPs no mesmo gene estão sendo avaliados quanto a sua relação com outras condições, como esclerose múltipla por exemplo $^{(110,111)}$. 
SNPs no receptor MT1 já foram avaliados quanto a sua associação com a Síndrome dos ovários policísticos, Doença de Graves, DM gestacional e complicações cardiovasculares, como infarto agudo do miocárdio (rs23883653) ${ }^{(111-115)}$.

Apesar dos efeitos antioxidantes da melatonina estarem sendo explorados em diferentes situações clínicas, até o momento não existem estudos explorando a participação de SNPs em genes relacionadas à síntese e ação da melatonina na susceptibilidade às complicações crônicas do DM. 


\section{OBJETIVOS}

Este estudo teve o objetivo de investigar a participação da melatonina na susceptibilidade às complicações crônicas microvasculares em indivíduos com DM1, avaliando especificamente:

(1) A associação entre SNPs nos genes que codificam duas enzimas responsáveis pela síntese da melatonina (ASMT e $A A N A T)$ e o receptor de melatonina MT1 (MTNR1A) e as complicações microvasculares e

(2) A associação entre as concentrações urinárias do principal metabólito da melatonina (aMT6s) e as complicações microvasculares. 
3 MATERIAL E MÉTODOS 


\section{MATERIAL E MÉTODOS}

\subsection{CASUÍSTICA}

Tendo em vista os objetivos propostos, os seguintes grupos foram avaliados:

1) Um grupo de 489 indivíduos com DM1, avaliado quanto a associação de SNPs com as complicações crônicas;

2) Um grupo de 98 indivíduos com DM1, avaliado quanto às concentrações urinárias de aMT6s (dos quais 64 também estavam no grupo de 489 indivíduos);

3) Um grupo de 30 indivíduos controle sem DM1 (pareados para idade e sexo com o subgrupo de 98 indivíduos), avaliado quanto às concentrações urinárias de aMT6s.

O projeto foi submetido e aprovado pelo Comitê de Ética em Pesquisa sob o número 1.511.697 em abril de 2016 (Anexo 1) e todos os participantes assinaram o Termo de consentimento livre e esclarecido (TCLE) conforme Anexo 2.

Para a análise da associação dos SNPs selecionados com as complicações crônicas, foram utilizados dados demográficos, clínicos e laboratoriais de indivíduos com DM1 incluídos no Banco de DNA de complicações crônicas, que começou a ser coletado no ano de 2005 no Ambulatório de Diabetes da Divisão de Endocrinologia do Hospital das Clínicas da Faculdade de Medicina da Universidade de São Paulo (HCFMUSP). Foram considerados elegíveis indivíduos com história de DM após os 6 meses de vida que evoluíram em menos de um ano para necessidade de uso de insulina, com a presença de autoanticorpos positivos ou que tiveram episódios de cetoacidose 
diabética. Esses indivíduos deveriam ter passado por períodos de controle glicêmico inadequado em algum período da vida e deveriam ter mais de 10 anos de doença. Para a presente análise, foram utilizados dados coletados no período de 2005 até 2016.

Para a avaliação da concentração de aMT6s, foram recrutados indivíduos com DM1 com mais de 10 anos de diagnóstico acompanhados no mesmo ambulatório. Os critérios de elegibilidade deste grupo foram os mesmos do anterior, no entanto, foram considerados não elegíveis indivíduos submetidos à transplante renal ou em terapia renal substitutiva (diálise), usuários de melatonina, indivíduos que estiveram hospitalizados até cinco dias antes da data da coleta de urina e gestantes.

\subsubsection{Análise de SNPs}

No período de 2005 a 2016, após assinatura do TCLE, todos os indivíduos com DM1 foram entrevistados e examinados e tiveram seus prontuários médicos revisados para coleta das informações clínicas e laboratoriais descritas a seguir e de acordo com Figura 1:

Dados pessoais, do diagnóstico de DM e de complicações relacionadas ao DM: sexo, idade atual, idade ao diagnóstico, tempo de diagnóstico, tempo para início da insulinização, controle glicêmico atual e pregresso, história de complicações microvasculares (retinopatia, doença renal diabética e neuropatia).

Doenças associadas: hipertensão arterial sistêmica (HAS), definida como pressão arterial >140/90mmHg em pelo menos três medidas, ou uso de medicações antihipertensivas não voltadas para proteção renal e dislipidemia, definida como uso de estatina e/ou colesterol LDL superior a $100 \mathrm{mg} / \mathrm{dL}$ (116).

Hábitos: tabagismo e etilismo. 
Medicações em uso: tipos de insulina (ou análogos de insulina) em uso, doses de cada tipo de insulina ou análogo, dose total de insulina, inibidores da enzima conversora da angiotensina (IECA), bloqueadores do receptor da angiotensina II (BRA) e hipolipemiantes.

História familiar: antecedentes familiares de DM1 e DM2.

Exame físico: dados antropométricos (peso e altura), incluindo cálculo de índice de massa corpórea (IMC) e avaliação da pressão arterial com o indivíduo sentado.

\section{Dados laboratoriais:}

- Hemoglobina glicada (HbA1c) - mensurada por cromatografia líquida de alta performance (HPLC) e certificada pela NGSP-EUA (National Glyco Hemoglobin Standardization Program) no momento da coleta de DNA e a média aritmética desta medida e das duas últimas medidas (realizadas em semestres diferentes).

- Glicemia de jejum - método enzimático hexoquinase.

- Frutosamina: método colorimétrico automatizado.

- Colesterol total e lipoproteína de alta densidade do colesterol (HDL-c): método enzimático colorimétrico automatizado.

- Lipoproteína de baixa densidade (LDL-c): método cinético automatizado.

- Triglicérides: método enzimático colorimétrico automatizado.

- Creatinina sérica: método colorimétrico automatizado.

- Excreção de albumina urinária (EAU): método nefrolometria.

Após entrevista e exame, foram coletados $4 \mathrm{~mL}$ de sangue periférico em tubo com EDTA mantido refrigerado até extração de DNA, realizada pelo método de Salting-Out (saturação de sal) ${ }^{(117)}$. 


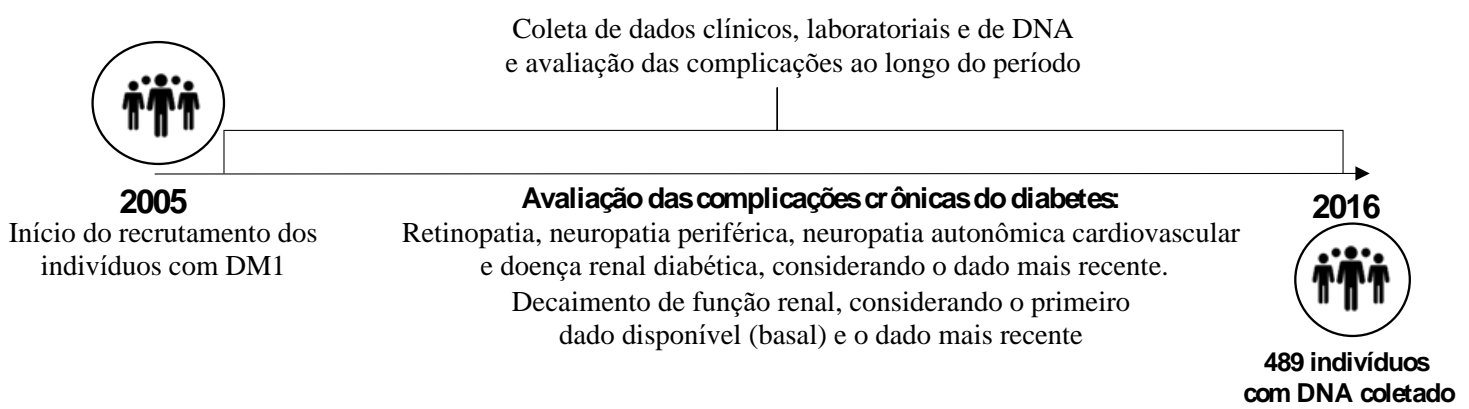

Figura 1 - Coleta de dados de indivíduos participantes do estudo de análise genética

\subsubsection{Dosagem de aMT6s urinária}

No período de 2016 a 2018, foram recrutados indivíduos com DM1 do mesmo ambulatório, para a dosagem de aMT6s urinária e avaliação de dados clínicos, conforme disposto na Figura 2. Estes indivíduos foram inicialmente contatados pelo pesquisador (presencialmente ou por telefone) e receberam coletores de urina sem reagentes adicionados, com capacidade para armazenar $2.000 \mathrm{~mL}$.

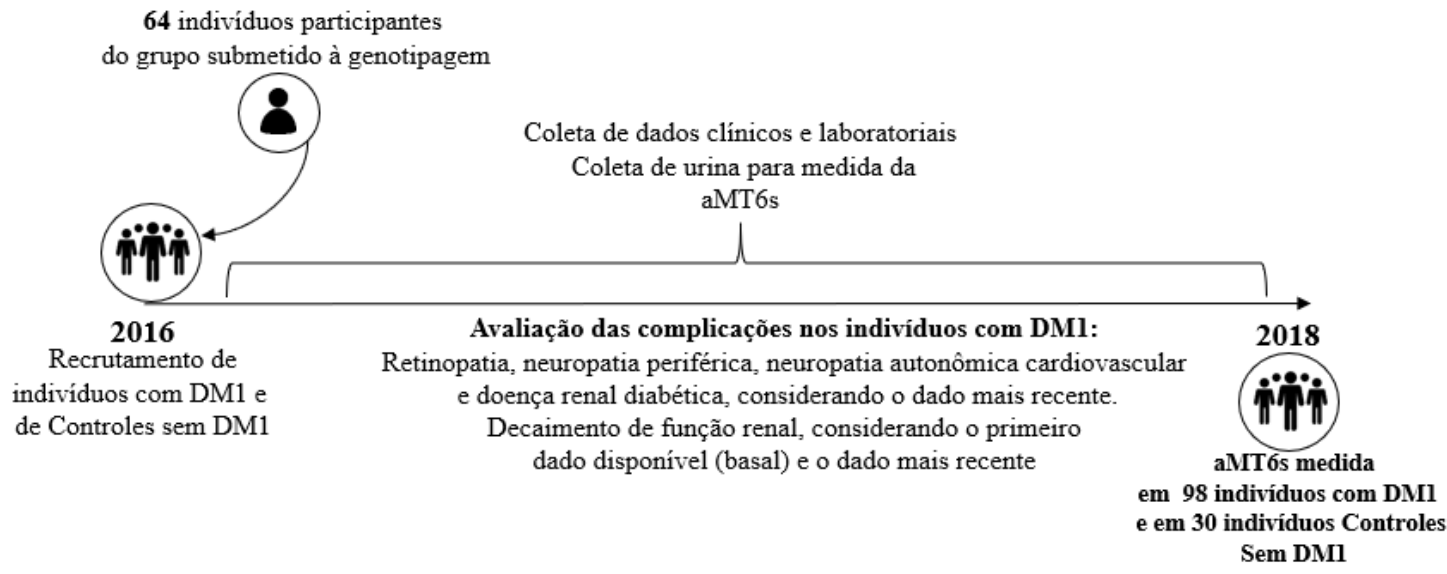

Figura 2 - Coleta de dados de indivíduos participantes da avaliação da concentração urinária de 6-sulfatoximelatonina (aMT6s) 
Todos os indivíduos foram orientados a realizar a coleta da urina dois dias antes da entrega da amostra no hospital, visando minimizar mudanças em sua rotina diária. Desse modo, foram orientados a coletar toda urina a partir das 19 horas até a hora do despertar no dia seguinte, incluindo a primeira urina da manhã. Os indivíduos também foram instruídos a manter o frasco de urina armazenado em geladeira comum até sua entrega no Ambulatório do hospital no dia seguinte.

No momento da entrega da urina coletada, todos os indivíduos foram submetidos à aplicação de questionários específicos de sonolência diurna (Escala de Sonolência de Eppworth) e de qualidade do sono (Índice de Qualidade do Sono de Pittsburg), ambos traduzidos e previamente validados em português $(118,119)$ (Anexo 3).

Esses indivíduos também foram questionados quanto ao uso de medicações, especificamente o uso de insulinas (e suas doses totais), IECA, BRA, betabloqueadores, bloqueadores de canal de cálcio, anti-hipertensivos diuréticos (tiazídicos ou de alça), estatinas, inibidores seletivos de receptação de serotonina (ISRS) ou benzodiazepínicos. Além disto, os participantes foram questionados quanto aos eventos ocorridos durante o período da coleta da amostra que poderiam relacionar-se ao padrão de sono (Anexo 4).

Os prontuários médicos foram revisados para a extração de dados complementares incluindo: idade atual, idade ao diagnóstico, tempo de diagnóstico, registro de complicações microvasculares (retinopatia, doença renal diabética e neuropatia), diagnóstico de HAS e dislipidemia tratadas, medida de IMC e resultado da média aritmética das últimas três HbA1c (realizadas em semestres diferentes).

Os indivíduos do grupo controle também preencheram o TCLE e foram submetidos aos mesmos questionamentos aplicados ao grupo de indivíduos com DM1. 
No momento da entrega do frasco coletor, o volume urinário total foi medido e registrado. Após esta etapa, amostras de $10 \mathrm{~mL}$ do volume total foram armazenadas a $80^{\circ} \mathrm{C}$ em refrigerador apropriado até o momento da realização da dosagem da aMT6s e da creatinina urinária.

\subsection{DEFINIÇÃO DAS COMPLICAÇÕES CRÔNICAS}

\subsubsection{Retinopatia diabética}

A avaliação da retinopatia diabética (RD) foi realizada pelo de exame de fundo de olho obtido com o uso de um retinógrafo (TOPCOM TRC-NW8) após dilatação da pupila com três gotas de colírio de tropicamida $(10 \mathrm{mg} / \mathrm{mL})$. Sete planos distintos foram fotografados (disco ótico, mácula, lateral temporal à mácula, súpero-nasal, temporal ao disco ótico, ínfero-temporal e nasal ao disco ótico).

As imagens foram armazenadas e posteriormente avaliadas por um mesmo médico oftalmologista especialista em retina, que classificou as imagens utilizando os critérios da International Clinical Classification of Diabetic Retinopathy ${ }^{(120)}$ :

- $\quad$ RD não proliferativa (RDNP) leve: apenas presença de microaneurismas;

- RDNP moderada: presença de microaneurismas, exudatos e/ou micro hemorragias em menor número que a RDNP grave;

- RDNP grave: Presença de mais de 20 hemorragias intrarretinianas em cada um dos quatro quadrantes; "ensalsichamento" venoso em pelo menos dois quadrantes; anormalidades microvasculares intrarretinianas (IRMAs) em pelo menos um quadrante; 
- RD proliferativa (RDP): Presença de neovascularização, hemorragia vítrea ou hemorragia pré-retiniana.

Em casos específicos de indivíduos com alterações retinianas naturais ou induzidas por procedimento em que a classificação por fotos não foi possível de ser realizada, o prontuário oftalmológico foi revisado e, quando disponível, o laudo obtido com base nestes dados.

Os indivíduos foram classificados em dois grupos para análise dos dados:

(1) Indivíduos sem RDP, grupo denominado "sem RDP”;

(2) Indivíduos com RDNP grave ou com RDP prévia ou atual ou com história de fotocoagulação com laser, grupo denominado “com RDP”.

\subsubsection{Neuropatia periférica}

A neuropatia periférica diabética (NP) é definida pela presença de sinais e sintomas de disfunção do nervo periférico após a exclusão de outras causas de neuropatia. Para o diagnóstico da NP, considerou-se a presença de sinais definidos no Escore de Comprometimento Neuropático - NDS (Neuropathy Disability Score) modificado e simplificado, associada a avaliação de sintomas definidos no Escore de Sintomas Neuropáticos - NSS (Neuropathy Symptoms Score) modificado. A somatória destes dois escores compõem ferramenta diagnóstica amplamente utilizada traduzida e validada em português ${ }^{(121,122)}$.

\subsubsection{Neuropatia autonômica cardiovascular}

A neuropatia autonômica cardiovascular (NAC) foi diagnosticada com a realização o exame de análise espectral padronizado de sete variáveis ${ }^{(123)}$. Os 
indivíduos foram avaliados no período da manhã, em jejum de no mínimo 2 horas e na ausência de condições capazes de alterar as respostas fisiológicas associadas à variabilidade da frequência cardíaca (FC), quais sejam, ingestão de cafeína há menos de 6 horas, uso de fármacos que alteram a FC (beta-bloqueadores) ou presença de hipoglicemia no momento do exame.

O traçado eletrocardiográfico realizado no momento do teste foi avaliado utilizando-se o programa Poly-Spectrum, que permite a comparação dos padrões encontrados com o esperado para a faixa etária e sexo de cada indivíduo.

Três índices foram extraídos da análise espectral a partir das variações espontâneas da FC de repouso: a atividade parassimpática refletida pelo índice HF (alta frequência; Variabilidade da FC [VFC] de alta frequência) - relacionado à arritmia sinusal; a atividade simpática refletida pelo índice VLF (muito baixa frequência, VFC de muito baixa frequência) - controle da termoregulação e da sudorese; e o controle simpático com a modulação vagal refletida pelo índice LF (baixa frequência, VFC de baixa frequência) - associação com o reflexo barorreceptor.

Posteriormente, estas medidas foram complementadas por avaliação da FC durante a execução de três manobras que avaliam reflexos autonômicos cardiovasculares, descritos como testes de Ewing:

- Manobra de respiração profunda: indivíduo monitorado em decúbito dorsal orientado a inspirar e expirar profundamente (aproximadamente 6 respirações por minuto). A variação eletrocardiográfica da FC máxima e mínima foi mensurada de acordo com a expiração e inspiração, gerando indicador próprio da variação da FC à respiração profunda (Beat-to-beat variation with deep breathing - E [expiration] : I [inspiration] ratio); 
- Manobra de Valsalva: indivíduo monitorado em decúbito dorsal orientado a manter expiração constante com força de $40 \mathrm{~mm} \mathrm{Hg}$, aferida por um manômetro, durante 15 segundos;

- Manobra de levantar-se (teste ortostático): indivíduo monitorado em decúbito dorsal em repouso foi orientado a ficar em ortostase rapidamente. A avaliação das alterações da FC no momento da mudança de decúbito que usualmente ocorrem no $15^{\circ}$ segundo (taquicardia) e no $30^{\circ}$ segundo (bradicardia) é chamada de relação 30:15.

Por fim, o último índice avaliado foi a possível presença da queda de pressão arterial sistólica após três minutos em pé; considerou-se hipotensão ortostática quedas superiores a 20 mm Hg da pressão arterial sistólica.

Para a definição quanto a presença de NAC foram considerados os seguintes critérios: NAC incipiente foi definida pela presença de dois testes alterados, NAC instalada foi definida pela presença de três testes alterados e NAC grave foi definida pela presença de três testes alterados associados à presença de hipotensão postural ${ }^{(124)}$.

Para a análise dos dados coletados foram considerados dois grupos:
(1) Sem NAC;
(2) Com NAC instalada ( $\geq$ três dos sete testes alterados) ${ }^{(124)}$.

\subsubsection{Doença renal diabética}

A doença renal diabética (DRD) foi definida pela presença de alterações em ao menos um de dois componentes: EAU ou taxa de filtração glomerular estimada $\left(\mathrm{TFG}_{\mathrm{e}}\right)$.

A EAU foi medida em pelo menos duas amostras isoladas de urina coletadas em um período de seis meses ou em ao menos uma dosagem de proteína em urina de 24 
horas. As medidas de EAU a partir de amostras de urina isoladas foram corrigidas pela concentração de creatinina urinária - razão de albumina/creatinina urinária (ACR). Esta razão foi utilizada para a definição do estágio de excreção de albumina:

- Valores normais: < $30 \mathrm{mg} / \mathrm{g}$ de creatinina;

- Microalbuminúria: $\geq 30$ - $300 \mathrm{mg} / \mathrm{g}$ de creatinina;

- Macroalbuminúria: > 300 mg/g de creatinina

A TFGe foi obtida com o uso da fórmula do CKD-EPI ${ }^{(125)}$ :

$\mathrm{TFGe}=141 \times \min (\text { Creatinina sérica } / \kappa, 1)^{\alpha} \mathrm{x}$ máximo $(\text { Creatinina sérica/ } \kappa, 1)^{-}$ ${ }^{1,209} \times 0,993^{\text {idade }} \times 1,018$ de mulher x 1,159 (se negro)

Sendo $\kappa=0,7$ se mulher e $\kappa=0,9$ se homem

Sendo $\alpha=-0,329$ se mulher e $\alpha=-0,411$ se homem

Min= Mínimo de Creatinina sérica/ $/$ ou 1

Max = Máximo de Creatinina sérica $/ \kappa$ ou 1

DRD foi definida como macroalbuminúria persistente e/ou TFGe $<60 \mathrm{~mL} / \mathrm{min} / 1.73 \mathrm{~m}^{2}$. Para a análise dos dados, os indivíduos foram agrupados da seguinte maneira:

(1) "sem DRD”;

(2) “com DRD”.

\subsubsection{Decaimento da função renal}

Além da análise transversal da DRD, também foi realizada uma análise de associação do decaimento da função renal com os SNPs, uma vez que os indivíduos incluídos no estudo tinham dados de TFGe ao longo do período de 2005 a 2016. As diferenças entre os valores mais recentes e mais antigos de TFGe foram divididas pelo 
número de anos de seguimento, para o cálculo do declínio anual da TFGe. Dessa análise foram excluídos indivíduos que quando da entrada no ambulatório já estavam em terapia renal substitutiva (hemodiálise) ou que tenham sido submetidos a um transplante renal.

Indivíduos que apresentaram um declínio da TFGe $\geq 5 \mathrm{~mL} / \mathrm{min} / 1.73 \mathrm{~m}^{2}$ ao ano ou evoluíram para ocorrência de desfecho renal (evolução para hemodiálise ou realização de transplante renal) foram considerados "declinantes" e comparados aos “não declinantes" (declínio da TFGe $<5 \mathrm{~mL} / \mathrm{min} / 1.73 \mathrm{~m}^{2}$ ).

\subsection{GENOTIPAGEM}

A partir do DNA coletado e armazenado, foram feitas reações em cadeia da polimerase (PCR) em tempo real no equipamento StepOnePlus (Applied Biosystems, Califórnia, EUA), para detecção das variantes alélicas de cada SNP. Para preparação da PCR, foram utilizados: TaqMan Genotyping Master Mix (conjunto de reagentes otimizados para genotipagem de SNPs, incluindo AmpliTaq Gold DNA polimerase, dNTPs sem dUTP, referência passiva e mistura de componentes otimizados) e TaqMan SNP Genotyping Assays (contendo duas sequências de primers específicos para amplificar o SNP de interesse; e duas sondas alelo-específicas TaqMan MGB, para detectar os alelos do SNP de interesse) (Applied Biosystems, CA, EUA). A presença de duas sondas em cada reação permite a genotipagem das duas possíveis variantes do SNP: a sonda do alelo 1 é marcada com o Reporter VIC, e a sonda do alelo 2 é marcada com o Reporter FAM, que apresentam fluorescências diferentes durante a reação. 
A escolha dos SNPs foi realizada na plataforma $L D$ TAG SNP Selection (National Institute of Environmental Health Science); foram selecionados TAG SNPs com frequência do alelo mínimo (MAF) de, pelo menos, $10 \%$ e que cobrissem aproximadamente $95 \%$ da variabilidade genética de cada um dos genes candidatos.

Os SNPs estudados em cada um dos genes avaliados no presente estudo foram: ASMT: rs6588810 e rs4446909;

AANAT: rs3760138, rs8150, rs3826287, rs12946216, rs4789300, rs7210907, rs12452844, rs12945905 e rs12951513;

MTNR1A： rs2165666, rs4862705, rs684769, rs117287777, rs6553010, rs1946977, rs7687823 e rs13140012.

\subsection{CONCENTRAÇÕES DE 6-SULFATOXIMELATONINA}

A dosagem de aMT6s urinária foi realizada nos laboratórios do Instituto de Ciências Biomédicas da USP utilizando-se do método ELISA e seguiu as instruções do fabricante do estojo comercial, sem alterações adicionais (RE54031 - IBL International). Paralelamente, outra alíquota da mesma amostra de urina foi analisada para a dosagem da creatinina urinária. Este experimento foi realizado no Laboratório Central do HCFMUSP utilizando o método colorimétrico cinético (Roche Cobas Roche, EUA) seguindo as instruções do fabricante. Os valores de creatinina urinária foram expressos em gramas por litros do volume total da amostra, sendo que este dado foi fornecido ao laboratório executor pelo pesquisador. 
Para a análise apropriada dos dados, utilizou-se a concentração de aMT6s urinária dividida pela concentração de creatinina urinária.

\subsection{ANÁLISES ESTATÍSTICAS}

As variáveis contínuas foram expressas como mediana e intervalo interquartílico e as variáveis categóricas foram expressas como número de casos e porcentagem de indivíduos afetados. O equilíbrio de Hardy-Weinberg (EHW) foi determinado usandose a frequência dos alelos por meio do teste do qui-quadrado $\left(\chi^{2}\right)$ de Pearson, utilizando-se o programa SPSS 13.0 para a análise dos dados.

Para a comparação das medianas das variáveis contínuas relativas às características entre os grupos estudados, foi utilizado o Teste de Mann-Whitney para amostras independentes. $\mathrm{O}$ teste do $\chi^{2}$ de Pearson também foi utilizado para avaliar as diferenças nas variáveis categóricas relativas às características entre os grupos estudados, bem como a associação com os SNPs.

A magnitude do risco conferido pelos SNPs foi estimada usando Odds ratio (OR) com intervalo de confiança (IC) de 95\% por análise de regressão logística binária. Para estimar a OR ajustada, uma análise de regressão logística binária foi realizada com as variáveis independentes significantemente diferentes para a variável dependente em questão.

Para o cálculo de significância realizou-se a correção por Bonferroni para todos os genes. Assim, o nível de significância adotado $(P)$ (bi-caudal) foi individualizado para cada gene de acordo com o número de SNPs testados. Deste modo, para o gene 
ASMT foi considerado significante um valor de $P<0,025$, para o gene $A A N A T$, um valor de $P<0,005$ e para o gene MTNR1A um valor de $P<0,006$.

A análise dos haplótipos foi realizada utilizando-se o software disponível online SHEsis. Todos os haplótipos com frequência <0,01 foram ignorados para a análise. Para a avaliação das diferentes combinações, utilizou-se o teste $\chi^{2}$ de Pearson com o valor de significância $(P)$ adotado $<0,05^{(126)}$. 


\section{RESULTADOS}

\subsection{AVALIAÇÃO GENÉTICA}

Os SNPs selecionados foram avaliados quando ao EHW usando-se a frequência dos alelos no teste do $\chi 2$ de Pearson, ao nível de significância de 0,05 e tiveram as MAFs calculadas, conforme Tabela 1. A distribuição dos genótipos de todos os SNPs selecionados respeitou o EHW.

Tabela 1 - Polimorfismos de um único nucleotídeo (SNPs) nos genes ASMT, AANAT e MTNRIA caracterizados quanto ao Equilíbrio de Hardy-Weinberg (EHW) e quanto à frequência do alelo raro (MAF)

\begin{tabular}{cccc}
\hline Gene & SNPs & EHW & MAF \\
\hline ASMT & rs6588810 & SIM & 0,115 \\
& rs4446909 & SIM & 0,204 \\
\hline AANAT & rs3760128 & SIM & 0,466 \\
& rs8150 & SIM & 0,309 \\
& rs3826287 & SIM & 0,429 \\
& rs12946216 & SIM & 0,451 \\
& rs4789300 & SIM & 0,487 \\
& rs7210907 & SIM & 0,204 \\
& rs12452844 & SIM & 0,289 \\
& rs12945905 & SIM & 0,154 \\
& rs12951513 & SIM & 0,094 \\
\hline MTN1A & rs265666 & SIM & 0,347 \\
& rs4862705 & SIM & 0,269 \\
& rs6847693 & SIM & 0,163 \\
& rs117287777 & SIM & 0,502 \\
& rs6553010 & SIM & 0,201 \\
& rs19466977 & SIM & 0,199 \\
& rs7687823 & SIM & 0,441 \\
& rs13140012 & SIM & 0,407 \\
\hline
\end{tabular}


As características demográficas, clínicas e laboratoriais mais recentes dos 489 indivíduos com DM1 incluídos no estudo estão mostradas na Tabela 2. Trata-se de um grupo de indivíduos com longo tempo de DM (mediana de 25 anos) e controle glicêmico inadequado (mediana da HbA1c de 8,3\%). HAS e dislipidemia estavam presentes em 44 e $34 \%$ dos indivíduos, respectivamente.

Tabela 2 - Características demográficas, clínicas e laboratoriais mais recentes da população de indivíduos com diabete melito tipo 1 avaliada

\begin{tabular}{lc}
\hline Características demográficas, clínicas e laboratoriais & $\mathbf{N}=\mathbf{4 8 9}$ \\
\hline Idade (anos) & $37(30-45,5)$ \\
Sexo (\% masculino) & $211(43)$ \\
Índice de massa corpórea $\left(\mathrm{kg} / \mathrm{m}^{2}\right)$ & $23,8(21,4-26,4)$ \\
Hipertensão arterial (\%) & 44 \\
Dislipidemia (\%) & 34 \\
Colesterol total (mg.dL $\left.{ }^{-1}\right)$ & $171(147-196)$ \\
HDL (mg.dL $\left.{ }^{-1}\right)$ & $58(46-69)$ \\
LDL (mg.dL $\left.{ }^{-1}\right)$ & $93(76-118)$ \\
Triglicérides (mg.dL $\left.{ }^{-1}\right)$ & $86(61-124)$ \\
TFGe (mL.min $\left.{ }^{-1} .1 .73 \mathrm{~m}^{2}\right)$ & $95(55-114)$ \\
Características do diabetes & \\
Duração do diabetes (anos) & $25(18-31,2)$ \\
Idade ao diagnóstico (anos) & $11(7-18)$ \\
HbA ${ }_{1} \mathrm{C}(\%)$ & $8,3(7,4-9,7)$ \\
Dose insulina/peso (UI/Kg) & $0,63(0,47-0,83)$ \\
Uso de medicamentos & \\
IECA (\%) & 26,3 \\
BRA (\%) & 11,4 \\
Estatinas (\%) & 35,7 \\
\hline
\end{tabular}

Resultados expressos como mediana e intervalo interquartílico. HDL: Lipoproteína de alta densidade; LDL: Lipoproteína de baixa densidade; TFGe: Taxa de filtração glomerular estimada; $\mathrm{HbA}_{1} \mathrm{C}$ : Hemoglobina glicada; IECA: Inibidores da enzima conversora da angiotensina; BRA: Bloqueadores do receptor de angiotensina II. 
Dentro desta casuística, 395 indivíduos foram avaliados quanto à presença de RD; 289 quanto à presença de NP, 291 quanto à presença de NAC; 485 quanto à presença de DRD e 411 foram caracterizados quanto ao declínio de sua função renal na avaliação longitudinal.

\subsubsection{Retinopatia Diabética}

A Tabela 3 mostra as características demográficas, clínicas e laboratoriais mais recentes dos 395 indivíduos com DM1 avaliados quanto à presença de RD.

Dos indivíduos com avaliação oftalmológica, 266 apresentavam RD (67,3\%). Observa-se que os indivíduos com RD quando comparados aos sem RD eram mais velhos $(39$ [32 - 47,2] vs. 31 [25,5 - 41] anos], tinham mais tempo de DM (27 [21 - 33] vs. 19 [14 - 25] anos), maior frequência de HAS (59,7\% vs. 27,9\%), de dislipidemia $(45,4 \%$ vs. $28,1 \%$, e, consequentemente, também utilizavam mais medicações para estas comorbidades. Os indivíduos com RD também apresentaram menores TFGe (84 [30 - 107] vs. 109 [89 - 119] mL/min/1,73m² ) quando comparados aos sem RD. 
Tabela 3 - Características demográficas, clínicas e laboratoriais mais recentes da população de indivíduos com diabete melito tipo 1 classificada de acordo com a ausência ou presença de retinopatia diabética (RD)

\begin{tabular}{|c|c|c|c|}
\hline & Ausência de RD & Presença de RD & Valor de $P$ \\
\hline \multicolumn{4}{|l|}{$\begin{array}{l}\text { Características demográficas, } \\
\text { clínicas e laboratoriais }\end{array}$} \\
\hline $\mathrm{N}$ & 129 & 266 & \\
\hline Idade (anos) & $31(25,5-41)$ & $39(32-47,2)$ & $<0,001$ \\
\hline Sexo (\% masculino) & 39,5 & 42,8 & 0,53 \\
\hline $\begin{array}{l}\text { Índice de massa corpórea } \\
\left(\mathrm{kg} / \mathrm{m}^{2}\right)\end{array}$ & $23,5(21,7-26,5)$ & $23,8(21,4-26,6)$ & 0,81 \\
\hline Hipertensão arterial (\%) & 27,9 & 59,7 & $<0,0001$ \\
\hline Dislipidemia (\%) & 28,1 & 45,4 & 0,001 \\
\hline Colesterol total $\left(\mathrm{mg} \cdot \mathrm{dL}^{-1}\right)$ & $171(149-192)$ & $170(144-197)$ & 0,96 \\
\hline $\mathrm{HDL}\left(\mathrm{mg} \cdot \mathrm{dL}^{-1}\right)$ & $60(50-69)$ & $57(45-69)$ & 0,13 \\
\hline $\mathrm{LDL}\left(\mathrm{mg} \cdot \mathrm{dL}^{-1}\right)$ & $93(77-106)$ & $93(75-111)$ & 0,54 \\
\hline Triglicérides $\left(\mathrm{mg} \mathrm{dL}^{-1}\right)$ & $79(58-106)$ & $83(60-124)$ & 0,16 \\
\hline TFGe $\left(\mathrm{ml} \cdot \mathrm{min}^{-1} .1 .73 \mathrm{~m}^{2}\right)$ & $109(89-119)$ & $84(30-107)$ & $<0,0001$ \\
\hline \multicolumn{4}{|l|}{ Características do diabetes } \\
\hline Duração do diabetes (anos) & $19(14-25)$ & $27(21-33)$ & $<0,0001$ \\
\hline Idade ao diagnóstico (anos) & $12(6-18)$ & $11(6-18)$ & 0,27 \\
\hline $\mathrm{HbA}_{1} \mathrm{C}(\%)$ & $8,2(7,4-9,3)$ & $8,3(7,4-9,4)$ & 0,58 \\
\hline Frutosamina $(\mu \mathrm{mol} / \mathrm{L})$ & $375(335-434)$ & $373(321-432)$ & 0,38 \\
\hline Dose de insulina/peso (UI/Kg) & $0,64(0,48-0,85)$ & $0,62(0,47-0,85)$ & 0,87 \\
\hline \multicolumn{4}{|l|}{ Uso de medicamentos } \\
\hline IECA $(\%)$ & 19 & 30 & 0,0005 \\
\hline BRA $(\%)$ & 7,7 & 15,4 & 0,03 \\
\hline Estatinas $(\%)$ & 33 & 45 & 0,02 \\
\hline
\end{tabular}

Resultados expressos como mediana e intervalo interquartílico. HDL: Lipoproteína de alta densidade; LDL: Lipoproteína de baixa densidade; TFGe: Taxa de filtração glomerular estimada; $\mathrm{HbA}_{1} \mathrm{C}$ : Hemoglobina glicada; IECA: Inibidores da enzima conversora da angiotensina; BRA: Bloqueadores do receptor de Angiotensina II; $P \leq 0,05$ foi considerado significante. 


\subsubsection{Neuropatia Periférica}

Do grupo de 289 indivíduos com avaliação para NP, 101 (34,9\%) apresentavam essa complicação. A Tabela 4 mostra as características mais recentes demográficas, clínicas e laboratoriais dos indivíduos de acordo com a ausência ou presença dessa complicação.

A avaliação deste grupo de 289 mostrou que os indivíduos portadores de NP, quando comparados aos indivíduos sem NP, eram mais velhos (39 [33,5 - 50] vs. 34 (28 - 41,5) anos, respectivamente), tinham maior tempo de doença (27 [21 - 34,5 vs. 22 [17,6 - 29] anos, respectivamente), apresentavam maiores valores de triglicérides (84 [64 - 121] vs. 76 [57 - 97,5] mg/dL, respectivamente), menores TFGe $(67$ [16,5 - 97,5] vs. $\left.104[86-118] \mathrm{mL} / \mathrm{min} / 1,73 \mathrm{~m}^{2}\right)$, maior prevalência de $\operatorname{HAS}(72,2 \%$ vs. 38,1\%, respectivamente) e de dislipidemia $(54,4 \%$ vs. $39,7 \%$, respectivamente) e maior frequência de uso de IECA $(40,5 \%$ vs $28,7 \%)$ e de estatina $(52,4 \%$ vs. $37 \%$, respectivamente) que os indivíduos sem NP. 
Tabela 4 - Características demográficas, clínicas e laboratoriais mais recentes da população de indivíduos com diabete melito tipo 1 classificada de acordo com a ausência ou presença de neuropatia periférica (NP)

\begin{tabular}{|c|c|c|c|}
\hline & Ausência NP & Presença NP & Valor de $P$ \\
\hline \multicolumn{4}{|l|}{$\begin{array}{l}\text { Características demográficas, } \\
\text { clínicas e laboratoriais }\end{array}$} \\
\hline $\mathrm{N}$ & 181 & 101 & \\
\hline Idade (anos) & $34(28-41,5)$ & $39(33,5-50)$ & $<0,0001$ \\
\hline Sexo (\% masculino) & 38,6 & 45,5 & 0,31 \\
\hline $\begin{array}{l}\text { índice de massa corpórea } \\
\left(\mathrm{kg} / \mathrm{m}^{2}\right)\end{array}$ & $24(21,9-26,3)$ & $23,2(20,9-25,9)$ & 0,14 \\
\hline Hipertensão arterial (\%) & 38,1 & 72,2 & $<0,0001$ \\
\hline Dislipidemia (\%) & 39,7 & 54,4 & 0,01 \\
\hline Colesterol total $\left(\mathrm{mg} \cdot \mathrm{dL}^{-1}\right)$ & $171(148,5-193,5)$ & $170(146-200)$ & 0,84 \\
\hline $\mathrm{HDL}\left(\mathrm{mg} \cdot \mathrm{dL}^{-1}\right)$ & $59(47,5-73)$ & $55(43-67,5)$ & 0,05 \\
\hline $\mathrm{LDL}\left(\mathrm{mg} \cdot \mathrm{dL}^{-1}\right)$ & $94(78-107,5)$ & $94(80-111,5)$ & 0,46 \\
\hline Triglicérides $\left(\mathrm{mg} \mathrm{dL}^{-1}\right)$ & $76(57-97,5)$ & $84(64-121)$ & 0,01 \\
\hline TFGe $\left(\mathrm{mL} \cdot \mathrm{min}^{-1} \cdot 1.73 \mathrm{~m}^{2}\right)$ & $104(86-118)$ & $67(16,5-97,5)$ & $<0,0001$ \\
\hline \multicolumn{4}{|l|}{ Características do diabetes } \\
\hline Duração do diabetes (anos) & $22(17,5-29)$ & $27(21-34,5)$ & 0,0004 \\
\hline Idade ao diagnóstico (anos) & $11(5-16,5)$ & $12(7-18)$ & 0,09 \\
\hline $\mathrm{HbA}_{1} \mathrm{C}(\%)$ & $8,2(7,35-9,11)$ & $8,3(7,28-9,87)$ & 0,43 \\
\hline Frutosamina $(\mu \mathrm{mol} / \mathrm{L})$ & $368(322-415)$ & $364(308,8-448)$ & 0,78 \\
\hline $\begin{array}{l}\text { Dose de insulina/peso } \\
(\mathrm{UI} / \mathrm{Kg})\end{array}$ & $0,60(0,47-0,79)$ & $0,57(0,42-0,81)$ & 0,13 \\
\hline \multicolumn{4}{|l|}{ Uso de medicamentos } \\
\hline $\operatorname{IECA}(\%)$ & 28,7 & 40,5 & 0,04 \\
\hline BRA $(\%)$ & 13,2 & 15,8 & 0,59 \\
\hline Estatinas (\%) & 37,0 & 52,4 & 0,01 \\
\hline
\end{tabular}

Resultados expressos como mediana e intervalo interquartílico. HDL: Lipoproteína de alta densidade; LDL: Lipoproteína de baixa densidade; TFGe: Taxa de filtração glomerular estimada; $\mathrm{HbA}_{1} \mathrm{C}$ : Hemoglobina glicada; IECA: Inibidores da enzima conversora da angiotensina; BRA: Bloqueadores do receptor de Angiotensina II; $P \leq 0,05$ foi considerado significante. 


\subsubsection{Neuropatia Autonômica Cardiovascular}

Um total 291 indivíduos foram avaliados quanto a NAC, que esteve presente em 29,2\% dos indivíduos. As características demográficas, clínicas e laboratoriais mais recentes dos indivíduos com e sem NAC estão descritas na Tabela 5.

Os indivíduos com NAC, quando comparados aos indivíduos sem NAC, apresentaram maior prevalência de HAS (69\% vs. 42\%, respectivamente), maiores concentrações de triglicérides (91 [64 - 127] vs. 76 [56 - 99] mg/dL, respectivamente), maior valor de $\mathrm{HbA}_{1} \mathrm{C}(8,4 \%$ [7,3 - 9] vs. 8,1 [7,3 - 9,0], respectivamente) e menor valor de TFGe $\left(64[10-102,5]\right.$ vs. 100 [77,8 - 114] $\mathrm{mL} / \mathrm{min} / 1,73 \mathrm{~m}^{2}$, respectivamente). 
Tabela 5 - Características demográficas, clínicas e laboratoriais mais recentes da população de indivíduos com diabete melito tipo 1 classificada de acordo com a ausência ou presença de neuropatia autonômica cardiovascular (NAC)

\begin{tabular}{|c|c|c|c|}
\hline & Ausência NAC & Presença NAC & Valor de $P$ \\
\hline \multicolumn{4}{|l|}{$\begin{array}{l}\text { Características demográficas, } \\
\text { clínicas e laboratoriais }\end{array}$} \\
\hline $\mathrm{N}$ & 206 & 85 & \\
\hline Idade (anos) & $37(29-47)$ & $35(31-44)$ & 0,42 \\
\hline Sexo (\% masculino) & 42 & 41 & 0,89 \\
\hline $\begin{array}{l}\text { Índice de massa corpórea } \\
\left(\mathrm{kg} / \mathrm{m}^{2}\right)\end{array}$ & $24(21,7-26,3)$ & $23,1(21-26,2)$ & 0,13 \\
\hline Hipertensão arterial (\%) & 42 & 69 & $<0,0001$ \\
\hline Dislipidemia (\%) & 42,7 & 51,8 & 0,19 \\
\hline Colesterol total $\left(\mathrm{mg} \cdot \mathrm{dL}^{-1}\right)$ & $171(149-192)$ & $173(140-210)$ & 0,65 \\
\hline $\operatorname{HDL}\left(m g \cdot d L^{-1}\right)$ & $59(46-73)$ & $57(44-66)$ & 0,19 \\
\hline $\operatorname{LDL}\left(m g \cdot d L^{-1}\right)$ & $93(80-106)$ & $97(75-121)$ & 0,46 \\
\hline Triglicérides $\left(\mathrm{mg} \cdot \mathrm{dL}^{-1}\right)$ & $76(56-99)$ & $91(64-127)$ & 0,0009 \\
\hline TFGe $\left(\mathrm{mL} \cdot \mathrm{min}^{-1} \cdot 1.73 \mathrm{~m}^{2}\right)$ & $100(77,8-114)$ & $64(10-102,5)$ & $<0,0001$ \\
\hline \multicolumn{4}{|l|}{ Características do diabetes } \\
\hline Duração do diabetes (anos) & $23,5(18-30,3)$ & $25(18,5-31)$ & 0,74 \\
\hline Idade ao diagnóstico (anos) & $12(7-19)$ & $11(5-16)$ & 0,11 \\
\hline $\mathrm{HbA}_{1} \mathrm{C}(\%)$ & $8,1(7,3-9)$ & $8,4(7,5-8,4)$ & 0,01 \\
\hline Frutosamina $(\mu \mathrm{mol} / \mathrm{L})$ & $366,5(322-415)$ & $384(318,5-486,5)$ & 0,14 \\
\hline Dose de insulina/peso (UI/Kg) & $0,60(0,44-0,82)$ & $0,57(0,45-0,80)$ & 0,80 \\
\hline \multicolumn{4}{|l|}{ Uso de medicamentos } \\
\hline IECA $(\%)$ & 31 & 40 & 0,17 \\
\hline $\mathrm{BRA}(\%)$ & 11,7 & 17,7 & 0,19 \\
\hline Estatinas (\%) & 40,8 & 50,6 & 0,15 \\
\hline
\end{tabular}

Resultados expressos como mediana e intervalo interquartílico. HDL: Lipoproteína de alta densidade; LDL: Lipoproteína de baixa densidade; TFGe: Taxa de filtração glomerular estimada; $\mathrm{HbA}_{1} \mathrm{C}$ : Hemoglobina glicada; IECA: Inibidores da enzima conversora da angiotensina; BRA: Bloqueadores do receptor de Angiotensina II; $P \leq 0,05$ foi considerado significante. 


\subsubsection{Doença Renal Diabética}

A tabela 6 mostra as principais características demográficas, clínicas e laboratoriais mais recentes do grupo de 485 indivíduos avaliados quando a presença ou ausência de DRD.

Os indivíduos com DRD, quando comparados aos indivíduos sem DRD, eram mais velhos [40 (34 - 49) vs. $35(28$ - 44) anos, respectivamente], apresentavam maior tempo de doença [27 (22 - 33) vs. $22(17-31)$ anos, respectivamente], menor IMC [22,5 (20 - 25,9) vs. $24(21,9-27,8) \mathrm{kg} / \mathrm{m}^{2}$, respectivamente], maior prevalência de HAS (73\% vs. 31\%, respectivamente) e de dislipidemia $(45,3 \%$ vs. $30 \%$, respectivamente), maiores concentrações de triglicérides (102 [70 - 143] vs. 81 [59$109] \mathrm{mg} / \mathrm{dL}$, respectivamente), menor dose de insulina por peso $(0,58[0,44-0,79] \mathrm{vs}$. $0,66[0,49-0,90] \mathrm{UI} / \mathrm{Kg}$, respectivamente), maior frequência de uso de estatina $(49,0 \%$ vs. 30,1\%, respectivamente) e, como esperado, menores valores de TFGe [19 (8 - 51) vs. $107(90-118,7) \mathrm{mL} / \mathrm{min} / 1,73 \mathrm{~m}^{2}$, respectivamente] e maior frequência do uso de IECA $(33,9 \%$ vs. $23,1 \%$, respectivamente) que é comumente utilizado como forma de diminuir a progressão da DRD. 
Tabela 6 - Características demográficas, clínicas e laboratoriais mais recentes da população de indivíduos com diabete melito tipo 1 classificada de acordo com a ausência ou presença de doença renal diabética (DRD)

\begin{tabular}{|c|c|c|c|}
\hline & Ausência DRD & Presença DRD & Valor de $P$ \\
\hline \multicolumn{4}{|l|}{$\begin{array}{l}\text { Características clínicas e } \\
\text { laboratoriais }\end{array}$} \\
\hline $\mathrm{N}$ & 332 & 153 & \\
\hline Idade (anos) & $35(28-44)$ & $40(34-49)$ & $<0,0001$ \\
\hline Sexo (\% masculino) & 41,8 & 47,0 & 0,32 \\
\hline Índice de massa corpórea $\left(\mathrm{kg} / \mathrm{m}^{2}\right)$ & $24(21,9-27,8)$ & $22,5(20-25,9)$ & 0,0005 \\
\hline Hipertensão arterial (\%) & 31,6 & 73 & $<0,0001$ \\
\hline Dislipidemia (\%) & 30 & 45,3 & 0,0017 \\
\hline Colesterol total $\left(\mathrm{mg} \mathrm{dL}^{-1}\right)$ & $171(148-195)$ & $171(142-201)$ & 0,73 \\
\hline HDL (mg.dL $\left.{ }^{-1}\right)$ & $58(47-69)$ & $56(43-69)$ & 0,15 \\
\hline LDL (mg.dL $\left.{ }^{-1}\right)$ & $93(78-110)$ & $91(70-111)$ & 0,62 \\
\hline Triglicérides (mg.dL ${ }^{-1}$ ) & $81(59-109)$ & $102(70-143)$ & $<0,0001$ \\
\hline TFGe $\left(\mathrm{mL} \cdot \mathrm{min}^{-1} \cdot 1.73 \mathrm{~m}^{2}\right)$ & $107(90-118,7)$ & $19(8-51)$ & $<0,0001$ \\
\hline \multicolumn{4}{|l|}{ Características do diabetes } \\
\hline Duração do diabetes (anos) & $22(17-31)$ & $27(22-33)$ & $<0,0001$ \\
\hline Idade ao diagnóstico (anos) & $11(6-18)$ & $12(8-18)$ & 0,39 \\
\hline $\mathrm{HbA}_{1} \mathrm{C}(\%)$ & $8,4(7,47-9,57)$ & $8,35(7,42-10,03)$ & 0,86 \\
\hline Frutosamina $(\mu \mathrm{mol} / \mathrm{L})$ & $374(327,5-427)$ & $377(308-472,5)$ & 0,99 \\
\hline Dose de insulina/peso (UI/Kg) & $0,66(0,49-0,90)$ & $0,58(0,44-0,79)$ & 0,03 \\
\hline \multicolumn{4}{|l|}{ Uso de medicamentos } \\
\hline $\operatorname{IECA}(\%)$ & 23,1 & 33,9 & 0,014 \\
\hline BRA $(\%)$ & 10,5 & 13,7 & 0,36 \\
\hline Estatinas (\%) & 30,1 & 49,0 & $<0,0001$ \\
\hline
\end{tabular}

Resultados expressos como mediana e intervalo interquartílico. HDL: Lipoproteína de alta densidade; LDL: Lipoproteína de baixa densidade; TFGe: Taxa de filtração glomerular estimada; $\mathrm{HbA}_{1} \mathrm{C}$ : Hemoglobina glicada; IECA: Inibidores da enzima conversora da angiotensina; BRA: Bloqueadores do receptor de Angiotensina II; $P \leq 0,05$ foi considerado significante. 


\subsubsection{Decaimento da Função Renal}

No total, foram coletados dados longitudinais de 411 indivíduos ao longo de um tempo médio de 7,3 anos, o que possibilitou avaliar a velocidade de declínio da função renal. A Tabela 7 apresenta os principais dados demográficos, clínicos e laboratoriais referentes ao início do seguimento ambulatorial (dados basais) de indivíduos declinantes e não declinantes.

O grupo de indivíduos com função renal declinante possuía no momento de sua entrada no banco de dados menor IMC [22,3 (20,2 - 25,3) vs. $23,5(21,8-25,8) \mathrm{kg} / \mathrm{m}^{2}$, respectivamente], maior prevalência de HAS (33,3\% vs. 20,3\%, respectivamente) e de dislipidemia (44,5\% vs. $19,6 \%$, respectivamente). Consequentemente apresentavam maiores concentração de colesterol total $(186$ [158 - 223] vs. 165 [143 - 188] mg/dL, respectivamente), de LDL (105 [82 - 142] vs. 87 [69 - 104] mg/dL, respectivamente) e de triglicérides (105 [72 - 144] vs. 66 [50 - 96] mg/dL, respectivamente) quando comparados aos indivíduos sem função renal declinante. 
Tabela 7 - Características demográficas, clínicas e laboratoriais basais da população de indivíduos com diabete melito tipo 1 classificada de acordo com a velocidade de declínio da taxa de filtração glomerular estimada

\begin{tabular}{|c|c|c|c|}
\hline & Não declinante & Declinante & Valor de $P$ \\
\hline \multicolumn{4}{|l|}{$\begin{array}{l}\text { Características demográficas, } \\
\text { clínicas e laboratoriais }\end{array}$} \\
\hline $\mathrm{N}$ & 312 & 99 & \\
\hline Idade (anos) & $29,5(22-40)$ & $29(24-37)$ & 0,95 \\
\hline Sexo (\% masculino) & 42,3 & 47,4 & 0,36 \\
\hline $\begin{array}{l}\text { Índice de massa corpórea } \\
\left(\mathrm{kg} / \mathrm{m}^{2}\right)\end{array}$ & $23,5(21,8-25,8)$ & $22,3(20,2-25,3)$ & 0,05 \\
\hline Hipertensão arterial (\%) & 20,3 & 33,3 & 0,02 \\
\hline Dislipidemia (\%) & 19,6 & 44,5 & $<0,0001$ \\
\hline Colesterol total $\left(\mathrm{mg} \cdot \mathrm{dL}^{-1}\right)$ & $165(143-188)$ & $186(158-223)$ & $<0,001$ \\
\hline $\mathrm{HDL}\left(\mathrm{mg} \cdot \mathrm{dL}^{-1}\right)$ & $60(52-73)$ & $59(48-73)$ & 0,31 \\
\hline $\mathrm{LDL}\left(\mathrm{mg} \cdot \mathrm{dL}^{-1}\right)$ & $87(69-104)$ & $105(82-142)$ & $<0,001$ \\
\hline Triglicérides $\left(\mathrm{mg} \cdot \mathrm{dL}^{-1}\right)$ & $66(50-96)$ & $105(72-144)$ & $<0,0001$ \\
\hline TFGe (mL.min $\left.{ }^{-1} .1 .73 \mathrm{~m}^{2}\right)$ & $111(93-125)$ & $105(77-127)$ & 0,16 \\
\hline \multicolumn{4}{|l|}{ Características do diabetes } \\
\hline Duração do diabetes (anos) & $17(10-24)$ & $16(12-22)$ & 0,59 \\
\hline Idade ao diagnóstico (anos) & $12(7-18)$ & $11(7-16)$ & 0,76 \\
\hline $\mathrm{HbA}_{1} \mathrm{C}(\%)$ & $8,4(7,2-9,9)$ & $8,2(7,6-10,1)$ & 0,71 \\
\hline
\end{tabular}

Resultados expressos como mediana e intervalo interquartílico. HDL: Lipoproteína de alta densidade; LDL: Lipoproteína de baixa densidade; TFGe: Taxa de filtração glomerular estimada; $\mathrm{HbA}_{1} \mathrm{C}$ : Hemoglobina glicada; IECA: Inibidores da enzima conversora da angiotensina; BRA: Bloqueadores do receptor de Angiotensina II; $P \leq 0,05$ foi considerado significante. 


\subsubsection{Gene $A S M T$}

Na avaliação quanto à distribuição dos genótipos dos dois SNPs selecionados do gene ASMT e o status das complicações avaliadas, a presença do alelo raro A no rs4446909 conferiu tendência a menor presença de RD $(P=0,07)$. Esta tendência tornouse estatisticamente significante após regressão logística considerando os potenciais fatores confundidores (OR: 0,61 , IC95\% $=0,41-0,91 ; P=0,016)$, conforme demostrado na Tabela 8 .

Tabela 8 - Frequência dos genótipos dos polimorfismos no gene ASMT de acordo com a ausência ou presença de retinopatia diabética (RD)

\begin{tabular}{lcccc}
\hline & Ausência de RD & Presença de RD & OR (IC 95\%) & Valor de $\boldsymbol{P}$ \\
\hline N & 129 & 266 & & \\
ASMT & & & & \\
rs6588810 & & & $0,91(0,53-1,57)$ & 0,7426 \\
AA & 0,016 & 0,015 & & \\
AG & 0,197 & 0,202 & & \\
GG & 0,787 & 0.783 & & $0,0160^{*}$ \\
MAF & 0,114 & 0,116 & & \\
rs4446909 & & & & \\
AA & 0,085 & 0,053 & & \\
AG & 0,334 & 0,282 & & \\
GG & 0,581 & 0,665 & & \\
MAF & 0,251 & 0,193 & & \\
\hline
\end{tabular}

OR: Odds ratio; IC: intervalo de confiança; OR para o alelo raro em um modelo co-dominante de regressão logística ajustada para idade, tempo de DM, presença de HAS, TFGe, uso de IECA, uso de BRA e uso de estatina. $P \leq 0,025$ foi considerado significante. 
Não se encontrou nenhuma associação entre os SNPs analisados e a presença das demais complicações testadas, conforme mostrado nas tabelas disponíveis no Anexo 5.

Como o gene ASMT está localizado na região pseudo-autossomica dos cromossomos X e Y, realizou-se análise adicional do rs4446909 e sua associação com RD mantendo ajustes já descritos, porém dividindo esta análise por sexo. Nesta avaliação a significância encontrada anteriormente se perdeu ao segmentarmos os indivíduos por sexo:

- Sexo feminino: OR=0,65; IC 95\%=0,38-1,08; $P=0,098$

- Sexo masculino OR=0,53; IC 95\%=0,25-1,07; $P=0,079$

Adicionalmente foram avaliadas as diferenças demográficas ou clínicas relevantes entre portadores do alelo A e os não portadores; observou-se que os portadores do alelo raro A possuíam IMC inferior aos não portadores [21,7 (19,7 - 24,3) vs. $23,8(21,4-26,6) \mathrm{Kg} / \mathrm{m}^{2}$, respectivamente; $\left.P=0,0069\right]$. Não foram encontradas outras diferenças entre os grupos (dados não mostrados). 
Na avaliação da associação entre haplótipos neste gene e complicações, os SNPs selecionados foram colocados na seguinte ordem para análise: rs6588810 e rs4446909. A combinação dos alelos AA associou-se a um maior risco de decaimento da função renal, conforme mostrado na Tabela 9. Ainda que esta associação tenha relevância estatística, é importante destacar que o número total de portadores deste haplótipo é limitado (10 no total).

Tabela 9 - Frequência do haplótipo AA do gene ASMT de acordo com o status do declínio da função renal

\begin{tabular}{ccccc}
\hline & Não Declinante & Declinante & OR (IC 95\%) & $\boldsymbol{P}$ \\
\hline $\mathbf{N}$ & 312 & 99 & & \\
AA & $9,88(0,016)$ & $9,73(0,050)$ & $3,239(1,31-7,97)$ & $0,007 *$ \\
\hline
\end{tabular}

Sequência dos SNPs: rs6588810, rs4446909. Resultados expressos em número absoluto (percentual).

Assim como na análise isolada do SNP, também foi realizada a avaliação adicional dos haplótipos e sua associação com declínio da função renal, segregando a análise de acordo com o sexo. Nesta subanálise, a associação encontrada perde a relevância estatística.

Não se encontrou nenhuma outra associação significante entre os haplótipos deste gene e as demais complicações avaliadas, incluindo RD (dado não mostrado). 


\subsubsection{Gene AANAT}

Não se encontrou nenhuma associação estatisticamente significante entre os nove diferentes SNPs selecionados e as diferentes complicações avaliadas, conforme resultados disponíveis no Anexo 5.

Para a análise de haplótipos, os SNPs foram organizados na seguinte ordem: rs3760138, rs8150, rs3826287, rs12946216, rs4789300, rs7210907, rs12452844, rs12945905 e rs12951513.

Nesta avaliação, a combinação GGGCCGGCC associou-se a um menor risco de RD, conforme mostrado na Tabela 10. Novamente, é importante destacar que o número de indivíduos com este haplótipo é muito pequeno (4 no total).

Tabela 10 - Frequência do haplótipo GGGCCGGCC de acordo com o status da retinopatia diabética $(\mathrm{RD})$

\begin{tabular}{ccccc}
\hline & Ausência de RD & Presença de RD & OR (CI 95\%) & P \\
\hline N & 129 & 266 & & \\
GGGCCGGCC & $5,68(0,025)$ & $2,64(0,005)$ & $0,212(0,04-0,92)$ & $0,023^{*}$ \\
\hline
\end{tabular}

Sequência dos SNPs: rs3760138, rs8150, rs3826287, rs12946216, rs4789300, rs7210907, rs 12452844, rs12945905, rs12951513. Resultados expressos em número absoluto (cada portador com dois haplótipos) e frequência relativa à população em questão. 
O haplótipo GGGATCGCC associou-se a um maior risco de NAC, no entanto, apenas dois indivíduos foram portadores deste haplótipo, conforme mostrado na Tabela 11.

Tabela 11 - Frequência do haplótipo GGGATCGCC de acordo com o status da neuropatia autonômica cardiovascular (NAC)

\begin{tabular}{ccccc}
\hline & Ausência de NAC & Presença de NAC & OR (CI 95\%) & $P$ \\
\hline N & 206 & 85 & & \\
GGGATCGCC & $0,89(0,002)$ & $2,73(0,018)$ & $7,920(1,07-58,3)$ & $0,045^{*}$ \\
\hline
\end{tabular}

Sequência dos SNPs: rs3760138, rs8150, rs3826287, rs12946216, rs4789300, rs7210907, rs 12452844, rs12945905, rs12951513. Resultados expressos em número absoluto (cada portador com dois haplótipos) e frequência relativa à população em questão.

Por fim, conforme mostrado na Tabela 12, na análise quanto ao decaimento da função renal, o haplótipo GGCACCGTT associou-se a maior risco de decaimento da função renal (número total de portadores do haplótipo de 30) e o haplótipo TGGATCGCC associou-se a um menor risco de decaimento da função renal (número total de portadores do haplótipo de 66).

Tabela 12 - Frequência dos haplótipos GGCACCGTT e TGGATCGCC de acordo com o status do declínio da função renal

\begin{tabular}{ccccc}
\hline & $\begin{array}{c}\text { Ausência de } \\
\text { Decaimento }\end{array}$ & $\begin{array}{c}\text { Presença de } \\
\text { Decaimento }\end{array}$ & OR (IC 95\%) & $\boldsymbol{P}$ \\
\hline N & 312 & 99 & & \\
GGCACCGTT & $32,8(0,059)$ & $21,8(0,124)$ & $2,176(1,22-3,85)$ & $0,006^{*}$ \\
TGGATCGCC & $99,4(0,180)$ & $18,1(0,103)$ & $0,495(0,29-0,84)$ & $0,008^{*}$ \\
\hline
\end{tabular}

Sequência dos SNPs: rs3760138, rs8150, rs3826287, rs12946216, rs4789300, rs7210907, rs 12452844, rs12945905, rs12951513. Resultados expressos em número absoluto (cada portador com dois haplótipos) e frequência relativa à população em questão. 
Não se encontrou nenhuma outra associação significante entre os haplótipos deste gene e as demais complicações avaliadas (dados não mostrados).

\subsubsection{Gene MTNR1A}

A presença do alelo raro A do rs4862705 associou-se a maior risco de decaimento da função renal $(P=0,0114)$, sendo que esta associação se confirmou após a análise de regressão logística com ajuste para potenciais fatores confundidores $(\mathrm{OR}=1,84 ;$ IC $95 \%=1.20-2.82 ; P=0,0046)$, conforme mostrado na Tabela 13 . Em análise adicional, não foram encontradas diferenças demográficas ou clínicas relevantes entre portadores do alelo A e os não portadores (dados não mostrados).

Nenhum outro SNP associou-se ao status do declínio da função renal e também não foram encontradas associações significantes entre os SNPs selecionados e as demais complicações avaliadas (Anexo 5). 
Tabela 13 - Frequência dos genótipos dos polimorfismos no gene MTNRIA de acordo com o status do declínio da função renal

\begin{tabular}{|c|c|c|c|c|}
\hline & Não Declinante & Declinante & OR (IC 95\%) & Valor de $P$ \\
\hline $\mathbf{N}$ & 312 & 99 & & \\
\hline \multicolumn{5}{|l|}{ MTNRIA } \\
\hline rs2165666 & & & $1,24(0,83-1,85)$ & 0,2789 \\
\hline TT & 0,423 & 0,444 & & \\
\hline TC & 0,433 & 0,394 & & \\
\hline $\mathrm{CC}$ & 0,144 & 0,162 & & \\
\hline MAF & 0,360 & 0,338 & & \\
\hline rs4862705 & & & $1,84(1,2-2,82)$ & $0,0046^{*}$ \\
\hline AA & 0,077 & 0,091 & & \\
\hline$A G$ & 0,330 & 0,485 & & \\
\hline GG & 0,593 & 0,424 & & \\
\hline MAF & 0,241 & 0,333 & & \\
\hline rs6847693 & & & $1,01(1,0-1,01)$ & 0,8312 \\
\hline TT & 0,032 & 0,020 & & \\
\hline $\mathrm{TC}$ & 0,276 & 0,293 & & \\
\hline $\mathrm{CC}$ & 0,692 & 0,687 & & \\
\hline MAF & 0,169 & 0,166 & & \\
\hline rs11728777 & & & $0,95(0,63-1,45)$ & 0,8459 \\
\hline AA & 0,234 & 0,232 & & \\
\hline $\mathrm{AG}$ & 0,519 & 0,556 & & \\
\hline GG & 0,247 & 0,212 & & \\
\hline MAF & 0,493 & 0,510 & & \\
\hline rs6553010 & & & $1,28(0,48-3,31)$ & 0,6060 \\
\hline AA & 0,048 & 0,053 & & \\
\hline AG & 0,321 & 0,330 & & \\
\hline GG & 0,631 & 0,617 & & \\
\hline MAF & 0,208 & 0,218 & & \\
\hline rs1946977 & & & $1,18(0,72-1,90)$ & 0,4945 \\
\hline GG & 0,045 & 0,030 & & \\
\hline GT & 0,301 & 0,384 & & \\
\hline TT & 0,654 & 0,586 & & \\
\hline MAF & 0,195 & 0,222 & & \\
\hline rs7687823 & & & $0,96(0,63-1,46)$ & 0,8809 \\
\hline GG & 0,186 & 0,172 & & \\
\hline GA & 0,500 & 0,525 & & \\
\hline AA & 0,314 & 0,303 & & \\
\hline MAF & 0,435 & 0,434 & & \\
\hline rs13140012 & & & $0,86(0,55-1,33)$ & 0,5248 \\
\hline AA & 0,131 & 0,172 & & \\
\hline AT & 0,529 & 0,475 & & \\
\hline TT & 0,340 & 0,353 & & \\
\hline MAF & 0,395 & 0,409 & & \\
\hline
\end{tabular}

OR: Odds ratio; IC: intervalo de confiança; OR para o alelo raro em um modelo co-dominante de regressão logística ajustada para presença de HAS, triglicérides, LDL e TFGe na fase basal e uso de IECA. $P \leq 0,006$ foi considerado significante. 
Para a avaliação de haplótipos, os oito diferentes SNPs foram analisados na seguinte ordem: rs2165666, rs4862705, rs684769, rs117287777, rs6553010, rs1946977, rs7687823, rs13140012.

O haplótipo CACAGGAA - que inclui o alelo raro A do rs4862705 - associouse a maior risco de DRD $(\mathrm{OR}=4,187$; IC 95\%=1,07-17,2; $P=0,031)$ e maior risco de declínio da função renal $(\mathrm{OR}=7,326$, IC 95\%= 1,22-43,9; $P=0,010)$ conforme disposto na Tabela 14. Ressalta-se que o número total de indivíduos portadores deste haplótipo é muito pequeno (sete indivíduos na análise de DRD e três indivíduos na análise de função renal declinante).

Tabela 14 - Frequência do haplótipo CACAGGAA de acordo com a ausência ou presença de doença renal diabética (DRD) e com o status do declínio da função renal

\begin{tabular}{lcccc}
\hline & Ausência de DRD & Presença de DRD & OR $($ CI 95\%) & $P$ \\
\hline $\mathbf{N}$ & 332 & 153 & & \\
CACAGGAA & $5,72(0,019)$ & $2,93(0,004)$ & $4,187(1,01-17,2)$ & 0,031 \\
\hline \multicolumn{7}{c}{ Não Declinante } & Declinante & & \\
\hline N & 312 & 99 & & \\
CACAGGAA & $1,74(0,003)$ & $3,96(0,021)$ & $7,326(1,22-43,9)$ & 0,010 \\
\hline
\end{tabular}

Sequência dos SNPs: rs2165666, rs4862705, rs684769, rs117287777, rs6553010, rs1946977, rs7687823, rs13140012. Resultados expressos em número absoluto (cada portador com dois haplótipos) e frequência relativa à população em questão.

Nenhuma outra associação foi observada entre os demais haplótipos e as complicações avaliadas (dados não mostrados). 


\subsection{AVALIAÇÃO DA CONCENTRAÇÃO URINÁRIA DE aMT6}

Noventa e oito indivíduos coletaram urina no período noturno e foram submetidos à avaliação clínica e laboratorial presencial, além da revisão dos dados de prontuário; as amostras de quatro indivíduos foram excluídas da avaliação por descumprimento dos procedimentos necessários para coleta ou armazenamento das amostras.

As características gerais mais recentes do grupo de indivíduos com DM1 que coletou amostras de urina estão descritas na Tabela 15. Esse grupo foi composto por indivíduos de idade mediana de 37 anos, com predomínio do sexo feminino $(63,9 \%)$, que apresentavam longo tempo de DM (mediana de 24 anos) e controle glicêmico aquém do ideal (HbA1c de 8,1\%). Uma parcela considerável dos indivíduos não apresentava nenhuma complicação relacionada ao DM (46,3\%). Dentre as complicações avaliadas, a mais prevalente foi RD (27,9\%), seguida de NP (26,5\%). Cabe ressaltar, especialmente por ser uma análise de metabólito urinário, que apenas $19,1 \%$ foram caracterizados como portadores de DRD. Dentre as comorbidades avaliadas, a prevalência de HAS foi de 46,8\% e de dislipidemia foi de 52,1\%. Dos indivíduos avaliados, 32,9\% usavam IECA e 51\% usavam estatina.

O grupo controle sem DM1 apresentava mediana de idade de 35 anos e 63,4\% dos indivíduos era do sexo feminino, portanto pareados para o grupo de indivíduos com DM1 quanto à idade e sexo. As características deste grupo, em comparação ao grupo de indivíduos com DM1, estão descritas na Tabela 16. 
Tabela 15 - Características demográficas, clínicas e laboratoriais mais recentes dos indivíduos com diabete melito tipo 1 que coletaram urina para a dosagem da aMT6

\section{Características demográficas, clínicas e laboratoriais}

$\mathrm{N}$

Idade (anos)

Sexo (\% masculino)

Índice de massa corpórea $\left(\mathrm{kg} / \mathrm{m}^{2}\right)$

Hipertensão arterial (\%)

Dislipidemia (\%)
94

$37(30,7-47,5)$

36,1

$25,6(23,1-28,5)$

$46,8 \%$

$52,1 \%$

\section{Características do diabetes}

Duração do diabetes (anos)

$24(18-34)$

Idade ao diagnóstico (anos)

$13(6-18,2)$

$\mathrm{HbA}_{1} \mathrm{C}(\%)$

$8,1(7,3-9,1)$

Dose insulina/peso (UI/Kg)

$0,57(0,48-0,75)$

\section{Complicações crônicas}

Retinopatia diabética (\%)

Neuropatia periférica (\%)

NAC (\%)

Doença renal diabética (\%)

Ausência de qualquer complicação (\%)

\section{Uso de medicamentos}

IECA $(\%)$

BRA (\%)

Beta bloqueadores (\%)

Bloqueadores dos canais de cálcio (\%)

10,6

Diuréticos (\%)

Estatina (\%)

ISRS (\%)

Benzodiazepínicos (\%)

\section{Avaliação Sono}

Escala Eppworth

Escala Pittsburgh

Resultados expressos como mediana e intervalo interquartílico. $\mathrm{HbA}_{1} \mathrm{C}$ : Hemoglobina glicada; NAC: Neuropatia autonômica cardiovascular; IECA: inibidores da enzima conversora da angiotensina; BRA: Bloqueadores do receptor de angiotensina II; ISRS: Inibidores seletivos de recaptação da rerotonina; $P \leq$ 0,05 foi considerado significante. 
Tabela 16 - Comparação das características demográficas, clínicas e de sono dos indivíduos com diabete melito tipo 1 (DM1) e dos indivíduos controle sem DM1 que coletaram urina para a dosagem da aMT6

\begin{tabular}{lccc}
\hline & Indivíduos com DM1 & Controles sem DM1 & Valor de $\boldsymbol{P}$ \\
\hline $\mathrm{N}$ & 94 & 30 & \\
Idade (anos) & $37(30,7-47,5)$ & $35(31-38,2)$ & 0,1526 \\
Sexo (\% masculino) & 36,1 & 36,6 & 0.9607 \\
Hipertensão arterial (\%) & 46,8 & 10,0 & 0,0003 \\
Dislipidemia (\%) & 52,1 & 3,3 & $<0,0001$ \\
Avaliação Sono & & & \\
$\quad$ Escala Eppworth & $8,5(5-13)$ & $8,0(5,7-13)$ & 0,8469 \\
$\quad$ Escala Pittsburgh & $5,5(4-8)$ & $5,5(4-7,2)$ & 0,5030 \\
Tempo total de coleta (h) & $11,5(10,5-12,5)$ & $11(10,3-11,5)$ & 0,0034 \\
\hline
\end{tabular}

Resultados expressos como mediana e intervalo interquartílico. $P \leq 0,05$ foi considerado significante.

A prevalência de HAS e de dislipidemia foi maior entre os indivíduos com DM1 quando comparado ao grupo controle (HAS: 46,8\% vs. 10,06\%, respectivamente; dislipidemia: $52,1 \%$ vs. $3,3 \%$, respectivamente), sendo que o tempo total relatado de coleta - tempo designado entre às $19 \mathrm{~h}$ do dia anterior até o momento do despertar do dia seguinte - foi maior entre os portadores de DM1 quando comparado ao grupo controle $(11,5[10,5$ - 12,5] vs. 11 [10,3 - 11,5] horas). A avaliação da sonolência diurna e da qualidade do sono avaliados pelas respectivas escalas (Eppworth e Pittsburgh) foram similares entre os grupos. 
Na Tabela 17 estão descritas as concentrações urinárias de aMT6s corrigidas pela creatinina urinária dos grupos de indivíduos com DM1 e de controles sem DM1. O grupo de indivíduos com DM1 apresentou tendência de maior concentração urinária do metabólito em comparação ao grupo controle $(21,35$ [11,35 - 44,78] vs. 15,88 9,71 28,76] ng/mg, respectivamente, $P=0,0644)$. Quando realizamos a análise ajustada por fatores confundidores da secreção noturna de melatonina no dia da coleta, o valor passa a ser estatisticamente significante.

Tabela 17 - Concentrações de aMT6s urinária corrigidas pela creatinina dos indivíduos com diabete melito tipo 1 (DM1) e dos indivíduos controle sem DM1 que coletaram urina para a dosagem da aMT6

\begin{tabular}{lcccc}
\hline & $\begin{array}{c}\text { Indivíduos } \\
\text { com DM1 }\end{array}$ & $\begin{array}{c}\text { Controles } \\
\text { sem DM1 }\end{array}$ & $\begin{array}{c}\text { OR } \\
\text { (IC 95\%) }\end{array}$ & $\begin{array}{c}\text { Valor } \\
\text { de } \boldsymbol{P}\end{array}$ \\
\hline $\mathrm{N}$ & 94 & 30 & & \\
aMT6s/Creatinina & 21,35 & 15,88 & 1,03 & \\
urinária (ng/mg) & $(11,35-44,78)$ & $(9,71-28,76)$ & $(1,00-1,06)$ & $0,0087^{*}$ \\
\hline
\end{tabular}

$P$ ajustado para idade atual, sexo, se trabalhador noturno, se na noite da coleta assistiu televisão, computador, celular, usou tablet e se no meio da noite da coleta acendeu a luz: Resultados expressos como mediana e intervalo interquartílico. IC: Intervalo de confiança; OR: Odds ratio. $P \leq 0,05$ foi considerado significante 
Adicionalmente realizou-se uma avaliação das características demográficas, clínicas e laboratoriais mais recentes nos indivíduos com DM1 dividindo-os em dois grupos, de acordo com os valores de aMT6s encontrados, acima ou abaixo da mediana da concentração de aMT6s, considerando todos os indivíduos com DM1 que coletaram urina. A única diferença significante entre os dois grupos foi a maior frequência de indivíduos do sexo masculino no grupo com excreção abaixo da mediana $(50 \%$ vs 21,7\%, respectivamente), conforme demonstrado na Tabela 18. 
Tabela 18 - Características demográficas, clínicas e laboratoriais dos indivíduos com diabete melito tipo 1 apresentando concentrações de aMT6 urinária acima ou abaixo da mediana

\begin{tabular}{|c|c|c|c|}
\hline & $\begin{array}{c}\text { Abaixo da } \\
\text { Mediana }\end{array}$ & $\begin{array}{l}\text { Acima da } \\
\text { Mediana }\end{array}$ & Valor de $P$ \\
\hline \multicolumn{4}{|l|}{$\begin{array}{l}\text { Características demográficas, } \\
\text { clínicas e laboratoriais }\end{array}$} \\
\hline $\mathrm{N}$ & 48 & 46 & \\
\hline Idade (anos) & $38,5(32,2-48,5)$ & $36(29,7-47,5)$ & 0,5474 \\
\hline Sexo (\% masculino) & 50 & 21,7 & $0,0044^{*}$ \\
\hline Índice de massa corpórea $\left(\mathrm{kg} / \mathrm{m}^{2}\right)$ & $25,8(23,1-29,3)$ & $25,5(22,3-28,1)$ & 0,4405 \\
\hline Hipertensão arterial (\%) & 47,9 & 45,6 & 0,8259 \\
\hline Dislipidemia (\%) & 50 & 54,3 & 0,6732 \\
\hline \multicolumn{4}{|l|}{ Características do diabetes } \\
\hline Duração do diabetes (anos) & $25(19,2-34)$ & $23,5(17-32,2)$ & 0,3924 \\
\hline Idade ao diagnóstico (anos) & $12,5(6,2-18)$ & $13,5(6-20,2)$ & 0,5472 \\
\hline $\mathrm{HbA}_{1} \mathrm{C}(\%)$ & $8,2(7,5-9,3)$ & $7,9(7,2-8,7)$ & 0,1794 \\
\hline Dose insulina/peso (UI/Kg) & $0,56(0,47-0,86)$ & $0,59(0,48-0,7)$ & 0,9909 \\
\hline \multicolumn{4}{|l|}{ Complicações Diabéticas } \\
\hline Retinopatia diabética (\%) & 31,9 & 23,9 & 0,3900 \\
\hline Neuropatia periférica $(\%)$ & 29,1 & 23,9 & 0,5644 \\
\hline NAC $(\%)$ & 17 & 19,5 & 0,7510 \\
\hline Doença renal diabética (\%) & 20,8 & 17,3 & 0,6716 \\
\hline Ausência de complicações & 39,1 & 54,3 & 0,1435 \\
\hline \multicolumn{4}{|l|}{ Avaliação do Sono } \\
\hline Escala Eppworth & $9(5,2-11,7)$ & $8(5-13)$ & 0,9697 \\
\hline Escala Pittsburgh & $6(4-8)$ & $5(3-7,2)$ & 0,0801 \\
\hline \multicolumn{4}{|l|}{ Uso de medicamentos } \\
\hline $\operatorname{IECA}(\%)$ & 33,3 & 32,6 & 0,9404 \\
\hline $\operatorname{BRA}(\%)$ & 14,5 & 8,7 & 0,3747 \\
\hline Beta-bloqueadores (\%) & 14,5 & 4,3 & 0,0918 \\
\hline Bloqueadores de canais cálcio (\%) & 10,4 & 10,8 & 0,9432 \\
\hline Diuréticos (\%) & 12,5 & 6,5 & 0,3248 \\
\hline Estatinas $(\%)$ & 50 & 52,1 & 0,8331 \\
\hline IRSS (\%) & 16,6 & 21,7 & 0,5321 \\
\hline Benzodiazepínicos (\%) & 4,1 & 6,5 & 0,6110 \\
\hline
\end{tabular}

Resultados expressos como mediana e intervalo interquartílico. $\mathrm{HbA}_{1} \mathrm{C}$ : Hemoglobina glicada; NAC: Neuropatia autonômica cardiovascular; IECA: Inibidores da enzima conversora da angiotensina; BRA: Bloqueadores do receptor de angiotensina II; ISRS: Inibidores seletivos de recaptação de serotonina; $P \leq$ 0,05 foi considerado significante. 
Avaliou-se também a excreção de aMT6s nos indivíduos com DM1 agrupados quanto ao status de cada uma das complicações crônicas avaliadas. Não foram observadas diferenças entre os respectivos grupos, mesmo após ajuste para potenciais fatores confundidores, conforme mostrado na Tabela 19.

Tabela 19 - Concentrações de aMT6s urinária corrigida pela creatinina dos indivíduos com diabete melito tipo 1 agrupados de acordo com o status das complicações crônicas avaliadas

\begin{tabular}{|c|c|c|c|c|}
\hline $\begin{array}{l}\text { Retinopatia diabética } \\
\text { (RD) }\end{array}$ & Ausência RD & Presença RD & $\begin{array}{c}\text { OR } \\
(\text { IC 95\%) }\end{array}$ & $\begin{array}{l}\text { Valor } \\
\text { de } P\end{array}$ \\
\hline $\mathrm{N}$ & 67 & 26 & & \\
\hline $\begin{array}{l}\text { aMT6s/Creatinina } \\
\text { urinária (ng/mg) }\end{array}$ & $\begin{array}{c}23,7 \\
(11,3-44,6)\end{array}$ & $\begin{array}{c}17,8 \\
(10,9-53,1)\end{array}$ & $\begin{array}{c}1,01 \\
(0,98-1,03)\end{array}$ & 0,3737 \\
\hline $\begin{array}{l}\text { Neuropatia autonômica } \\
\text { cardiovascular (NAC) }\end{array}$ & Ausência NAC & Presença NAC & & $\begin{array}{l}\text { Valor } \\
\text { de } P\end{array}$ \\
\hline $\mathrm{N}$ & 76 & 17 & & \\
\hline $\begin{array}{l}\text { aMT6s/Creatinina } \\
\text { urinária (ng/mg) }\end{array}$ & $\begin{array}{c}21,3 \\
(11,4-43,5)\end{array}$ & $\begin{array}{c}29,7 \\
(11,4-46,8)\end{array}$ & $\begin{array}{c}1,01 \\
(0,98-1,03)\end{array}$ & 0,3887 \\
\hline $\begin{array}{l}\text { Neuropatia periférica } \\
\text { (NP) }\end{array}$ & Ausência NP & Presença NP & & $\begin{array}{l}\text { Valor } \\
\text { de } P\end{array}$ \\
\hline $\mathrm{N}$ & 69 & 25 & & \\
\hline $\begin{array}{l}\text { aMT6s/Creatinina } \\
\text { urinária (ng/mg) }\end{array}$ & $\begin{array}{c}23,1 \\
(12,04-49,44)\end{array}$ & $\begin{array}{c}18,1 \\
(9,53-33,7)\end{array}$ & $\begin{array}{c}1,00 \\
(0,98-1,03\end{array}$ & 0,4758 \\
\hline $\begin{array}{l}\text { Doença renal diabética } \\
\text { (DRD) }\end{array}$ & Ausência DRD & Presença DRD & & $\begin{array}{l}\text { Valor } \\
\text { de } P\end{array}$ \\
\hline $\mathrm{N}$ & 76 & 18 & & \\
\hline $\begin{array}{l}\text { aMT6s/Creatinina } \\
\text { urinária (ng/mg) }\end{array}$ & $\begin{array}{c}22,3 \\
(10,77-44,98)\end{array}$ & $\begin{array}{c}17,9 \\
(11,3-40,5)\end{array}$ & $\begin{array}{c}1,01 \\
(0,98-1,03)\end{array}$ & 0,4400 \\
\hline
\end{tabular}

Resultados expressos como mediana e intervalo interquartílico. P ajustado para se trabalhador noturno, se na noite da coleta assistiu televisão, computador, celular e se no meio da noite da coleta acendeu a luz: Resultados expressos como mediana e intervalo interquartílico. $P \leq 0,05$ foi considerado significante. IC: Intervalo de confiança; OR: Odds ratio. 


\subsubsection{Concentração de Melatonina Urinária e Análise Genética}

Um subgrupo de 64 indivíduos com DM1 coletou urina e teve material coletado para a análise genética relatada acima. Desses, três indivíduos tiveram suas amostras excluídas, conforme descrito anteriormente. As características gerais mais recentes deste subgrupo estão descritas na Tabela 20, sendo bastante similares às do grupo geral de concentração urinária.

Deste subgrupo de indivíduos, foram realizadas avaliações complementares para analisar possíveis associações entre os genótipos dos SNPs estudados e as concentrações urinárias de aMT6s, conforme relatado a seguir. 
Tabela 20 - Características demográficas, clínicas e laboratoriais dos indivíduos com diabete melito tipo 1 que coletaram urina para a dosagem da aMT6 e material genético

\section{Características demográficas, clínicas e laboratoriais}

$\mathrm{N}$

Idade (anos)

Sexo (\% masculino)

Índice de massa corpórea $\left(\mathrm{kg} / \mathrm{m}^{2}\right)$

Hipertensão arterial (\%)

Dislipidemia (\%)

\section{Características do diabetes}

Duração do diabetes (anos)

Idade ao diagnóstico (anos)

$\mathrm{HbA}_{1} \mathrm{C}(\%)$

Dose insulina/peso (UI/Kg)

\section{Complicações crônicas}

Retinopatia diabética (\%)

Neuropatia periférica (\%)

NAC $(\%)$

Doença renal diabética (\%)

Ausência de qualquer complicação (\%)

\section{Uso de medicamentos}

IECA $(\%)$

BRA (\%)

Beta Bloqueadores (\%)

Bloqueadores de canais de cálcio (\%)

Diuréticos $(\%)$

Estatinas (\%)

ISRS (\%)

Benzodiazepínicos (\%)

\section{Avaliação Sono}

Escala Eppworth

Escala Pittsburgh
61

$40(31,5-51)$

31,1

$25,7(23,1-29,7)$

$47,5 \%$

$34 \%$

$24(19-35,5)$

$15(8-22)$

$8,1(7,2-8,8)$

$0,59(0,51-0,77)$
31,1

26,2

18,0

19,6

36

11,4

11,4

11,4

8,1

54

24,5

4,9

$9(5-13,5)$

$6(4-8)$

Dosagem de aMT6s/Creatinina urinária (ng/mg)

$21,44(10,79-46,74)$

Resultados expressos como mediana e intervalo interquartílico. $\mathrm{HbA}_{1} \mathrm{C}$ : Hemoglobina glicada; NAC: Neuropatia autonômica cardiovascular; IECA: Inibidores da enzima conversora da angiotensina; BRA: Bloqueadores do receptor de angiotensina II; ISRS: Inibidores seletivos de recaptação de serotonina; $P \leq$ 0,05 foi considerado significante. 


\subsubsection{Gene ASMT}

Não foram encontradas diferenças significantes entre as concentrações de aMT6s na presença ou ausência do alelo raro A no SNP rs4446909, porém observou-se uma tendência de indivíduos portadores o alelo A apresentarem menor concentração de aMT6s quando comparados a indivíduos com a ausência do alelo A $(18,9$ [12,1 - 26,8] vs. $31,5[10,9-52,4]) \mathrm{ng} / \mathrm{mg}$, respectivamente $P=0,079]$ (Figura 3).

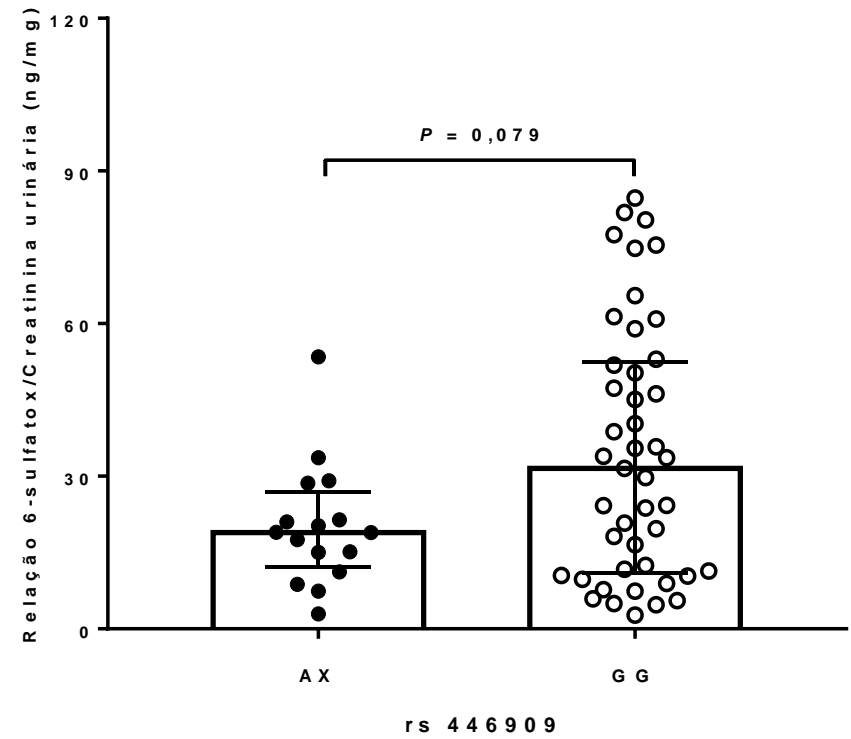

Figura 3 - Concentrações de aMT6s urinária de acordo com a presença ou ausência de alelo raro A no rs4446909 do gene ASMT (modelo codominante)

Após ajuste para a presença de DRD e de fatores potencialmente influenciadores na noite da coleta (uso de celular, tablet, televisão, computador e uso de luz no meio da noite da coleta), a associação de menor concentração de aMT6s com a presença do alelo raro A tornou-se estatisticamente significante $(\mathrm{OR}=0,96 ;$ IC $95 \%=0,92-0,99 ; P=$ 0,013). É relevante destacarmos que as características clínicas, demográficas, 
laboratoriais e relacionadas ao sono não diferiram entre indivíduos com DM1 com e sem a presença do alelo raro A do SNP rs4446909 (Anexo 6).

Considerando que o gene ASMT está localizado na região pseudoautossômica do cromossomo sexual, a mesma análise foi feita dividindo-se a casuística por sexo. No sexo feminino, a associação se manteve, mas ela não alcançou significância estatística no sexo masculino.

- Sexo feminino: OR=instável; $P=0,0091$

- Sexo masculino: $\mathrm{OR}=$ instável; $P=0,1342$

Finalmente, considerando o achado relacionado à presença do haplótipo AA e o maior risco de decaimento da função renal descrito na análise genética, tentou-se avaliar a possível associação entre as concentrações de AMT6s e a presença desse haplótipo. Contudo, havia apenas um indivíduo portador do haplótipo AA entre os indivíduos com urina coletada, o que inviabilizou a análise.

\subsubsection{Gene AANAT}

Não se encontrou associação entre as concentrações urinárias de aMT6s e a presença ou ausência do haplótipo GGGCCGGCC, que na análise genética associou-se a um menor risco de RD (dados não mostrados). De maneira similar, na presença do haplótipo GGGATCGCC, que na análise genética associou-se a maior risco de NAC, não se encontrou associação com as concentrações de aMT6s urinária (dados não mostrados).

Por fim, os haplótipos GGCACCGTT e TGGATCGCC, que foram associados ao decaimento da função renal, não se associaram às concentrações urinárias de aMT6s (dados não mostrados). 


\subsubsection{Gene MTNR1A}

Não se observou associação significante entre as concentrações de aMT6s urinária e a presença ou ausência do alelo raro A do rs4862705, que se associou a um maior risco de decaimento da função renal na análise genética (Anexo 6).

A análise da associação entre as concentrações de aMT6s urinária e o haplótipo CACAGGAA (que na análise genética associou-se a maior risco de DRD e de declínio da função renal), observou-se uma maior concentração de aMT6s em indivíduos portadores desse haplótipo em comparação com indivíduos com outros haplótipos $(59,2$ $[39,8-84,7]$ vs. $21,0[10,8-42,7] \mathrm{ng} / \mathrm{mg}$, respectivamente $P=0,015)$, conforme mostrado na Figura 4. Contudo, o número de indivíduos portadores desse haplótipo é extremamente reduzido (quatro, no total).

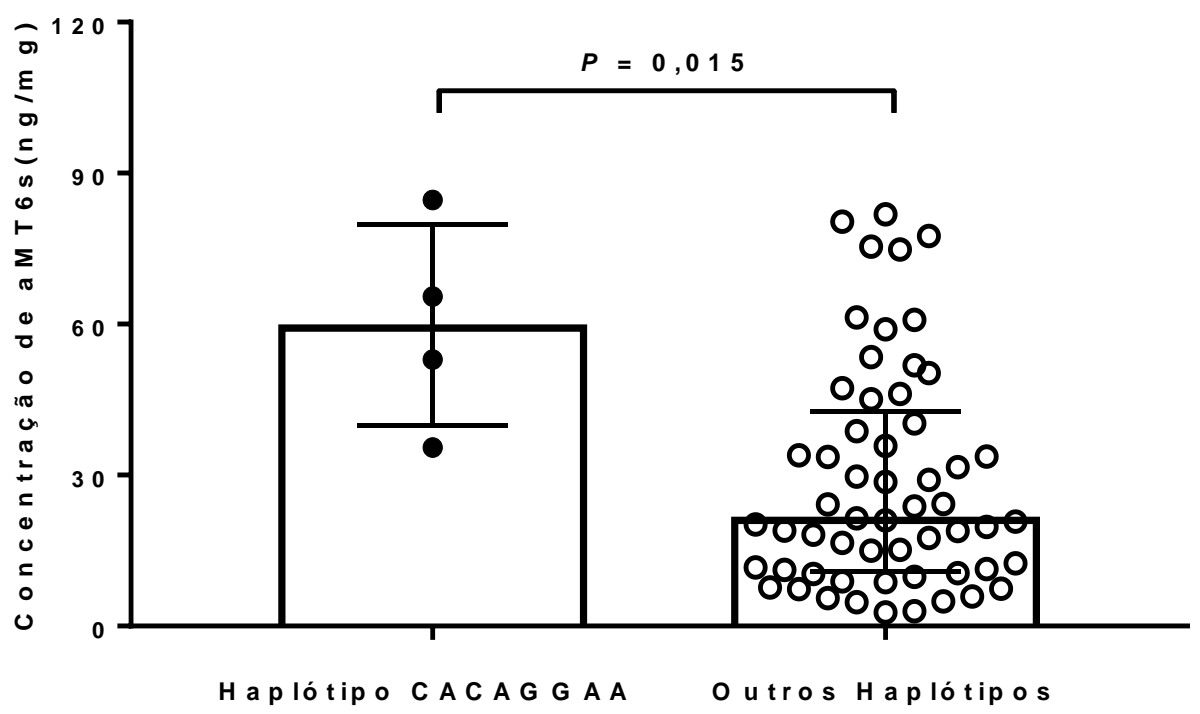

Figura 4 - Concentração de 6-sulfatoximelatonina urinária (ng/mg) de acordo com a presença do haplótipo CACAGGAA dos polimorfismos avaliados no gene MTNRIA 


\section{DISCUSSÃO}

A associação entre complicações crônicas em indivíduos com DM1 e o sistema melatonina (em todas suas funções) é pouco estudada na literatura. Até onde conhecemos, não há estudos publicados abordando a associação entre SNPs em genes relacionados à produção e ação da melatonina e complicações crônicas relacionados ao DM.

No presente estudo, foram selecionados SNPs nos genes que codificam as duas principais enzimas da via de síntese da melatonina e no gene que codifica um de seus receptores, com o objetivo de avaliar se variantes genéticas com potencial de afetar a produção, concentrações e ações da melatonina, um importante antioxidante, poderiam interferir na susceptibilidade às complicações crônicas em indivíduos com DM1.

\subsection{GENE ASMT}

No gene que codifica a ASMT, a presença do alelo raro A do SNP rs4446909 associou-se a um menor risco de desenvolvimento de RD. A RD é uma complicação extremamente frequente do DM, estima-se que um terço dos portadores de DM tenham algum grau de RD ${ }^{(127)}$. A patogênese da RD inclui aumento de ROS e de fatores próinflamatórios, além de alterações nas vias de autofagia, entre outras ${ }^{(128-132)}$.

Como já exposto, a melatonina tem ações diretas e indiretas, reduzindo o estresse oxidativo e a inflamação ${ }^{(15,68)}$. Estudos em modelos animais demonstraram que 
células da retina e da mácula expostas a melatonina apresentaram redução substancial de marcadores de oxidação e crescimento vascular ${ }^{(133,134)}$.

A relação de risco inversa entre RD e melatonina já foi estudada em indivíduos com DM2. Hikishi e cols. avaliaram um grupo de 30 indivíduos com DM2, divididos entre 14 portadores de RDP e 16 sem RDP, e 26 controles sem DM. Nestes grupos, foram coletadas amostras de melatonina sérica noturna e diurna, sendo observadas menores concentrações de melatonina nos indivíduos com DM2 quando comparados aos sem DM2 e menores concentrações de melatonina nos portadores de RDP quando comparados ao grupo sem RDP ${ }^{(94)}$. Mais recentemente, Kalere e cols. avaliaram, com a dosagem de melatonina salivar matinal, um grupo de 26 indivíduos com DM2 e 12 controles sem DM; uma diferença significante nas concentrações de melatonina foi observada entre os oito indivíduos com RD quando comparados aos 18 sem essa complicação ${ }^{(95)}$. É válido destacar que não encontramos na literatura estudos avaliando a associação entre RD e melatonina em indivíduos com DM1.

Vários estudos avaliaram o SNP rs4446909 em diferentes condições clínicas. Em um estudo multicêntrico realizado por Melke e cols., 250 indivíduos com autismo e síndrome de Asperger foram comparados a indivíduos sem essas condições clínicas. A presença do alelo comum $\mathrm{G}$ conferiu maior risco de desenvolvimento de autismo. Nesse estudo, uma avaliação funcional mostrou que a presença deste mesmo alelo $\mathrm{G}$ associouse a uma menor transcrição do gene $A S M T$, enquanto o alelo A associou-se a menor risco de autismo e maior atividade enzimática ${ }^{(135)}$.

Estudo com pacientes com transtorno afetivo bipolar demonstrou resultados semelhantes, inclusive mostrando atividade enzimática superior em portadores do alelo $\mathrm{A}^{(136)}$. Outros trabalhos reportaram que a presença do alelo raro A conferiu menor risco 
para depressão, e maior expressão da enzima ASMT nos indivíduos homozigotos AA $(103,105)$. Não encontramos nenhum estudo que tenha avaliado esse SNP específico no contexto do DM ou suas complicações, estudos que associassem a presença de variantes genéticas relacionadas às enzimas limitantes e as concentrações de melatonina ou estudos relacionados a essas variante e RD.

Considerando o exposto, parte desses estudos observaram (no contexto de doenças diferentes do DM) que a presença do alelo raro A no rs4446909 associou-se a maior atividade da enzima ASMT, o que, indiretamente, poderia indicar maior produção de melatonina. Contudo nenhum desses estudos avaliou as concentrações de melatonina ou de seus metabólitos com relação a presença do alelo em questão ${ }^{(101,103,135)}$.

No presente estudo exploratório, o alelo A no rs44469090 associou-se a um menor risco de RD, o que nos levou a levantar a hipótese que, na presença desse alelo, haveria uma maior atividade da enzima ASMT, resultando em maior concentração de melatonina e, assim, maior potencial antioxidante contra os insultos determinados pela hiperglicemia na retina. É importante salientar que a ASMT é sintetizada na retina neural, o que sugere que exista uma produção local de melatonina, que atua de forma autócrina e parácrina ${ }^{(137)}$. Portanto, o presente SNP poderia afetar a produção local de melatonina, mesmo não determinando diferenças perceptíveis nas concentrações sistêmicas do hormônio.

Adicionalmente, ao avaliarmos as características clínicas e laboratoriais entre portadores do alelo raro A e não portadores, encontramos um menor IMC entre os portadores desta variante. Estudos de diferentes grupos já mostraram o potencial efeito da melatonina (e sua suplementação) na regulação do peso e composição corporal ${ }^{(138-142)}$. Esta possível associação envolve uma complexa interação entre a 
melatonina e fatores relevantes no balanço energético, tais como modulação da termogênese, interação no tecido adiposo e esquelético ${ }^{(142)}$.

Deste modo, é possível especular que a diferença de IMC encontrada possa, novamente, relacionar-se com uma maior concentração local de melatonina entre portadores do alelo A, capaz de influenciar o metabolismo energético negativamente.

Para explorar a relação entre o SNP rs44469090 e a produção de melatonina, avaliamos a associação entre os genótipos e as concentrações urinárias de aMT6s. Na análise sem ajustes, encontramos uma tendência de menores concentrações urinárias de aMT6s em portadores do alelo raro A, que alcançou significância estatística após o ajuste para potenciais fatores de confusão. Pelo fato do gene $A S M T$ estar localizado na região pseudoautossômica do cromossomo sexual, os resultados observados foram reavaliados considerando os grupos de sexo masculino e feminino separadamente, e a menor concentração de aMT6s na presença do alelo raro A do rs4446909 somente se manteve significante em indivíduos do sexo feminino. Considerando que o alelo A já foi associado a uma maior atividade da ASMT, esses resultados foram contrários ao que se poderia esperar.

É importante destacar que o estudo das concentrações de melatonina em humanos, em situações não controladas, apresenta várias limitações, como as possíveis variações na produção do hormônio secundariamente a fatores ambientais, tais como época do ano, iluminação, temperatura ambiente, exposição à iluminação artificial, entre outros. No presente estudo, tentamos levar em consideração os principais fatores confundidores durante a realização da análise estatística, porém, nem todos os fatores ambientais foram explorados, o que poderia influenciar os resultados observados. Outra 
limitação do presente estudo é o fato da concentração urinária de aMT6s ter sido realizada em coleta única.

Portanto, a menor concentração do metabólito da melatonina entre os portadores do alelo raro A do rs4446909 pode decorrer das limitações citadas ou, ainda, tratar-se de um erro do tipo 1, relacionado ao pequeno tamanho da amostra que apresentava dados de genotipagem e coleta de urina. Diante da natureza exploratória desse estudo e da ausência de estudos na literatura que avaliaram a concentração de melatonina na presença deste SNP, estudos adicionais são necessários para melhor elucidar essa relação.

Finalmente, na análise de haplótipos dos dois SNPs avaliados no gene ASMT, a combinação AA - que inclui o alelo raro A do SNP rs4446909- associou-se um maior risco de decaimento de função renal em comparação aos não portadores desse haplótipo. O número total de portadores desta combinação na população estudada (10 indivíduos) é extremamente reduzido e não permite que se tirem conclusões sobre essa associação.

\subsection{GENE AANAT}

Nove diferentes SNPs foram avaliados no gene AANAT, mas não foram encontradas associações com nenhuma das complicações diabéticas. No entanto, na análise de haplótipos, algumas associações foram observadas.

Dois dos haplótipos avaliados (GGGCCGGCC e GGGATCGCC) tiveram sua presença associada, respectivamente, a um menor risco para RD e a um maior risco para NAC. Contudo, o número extremamente limitado de portadores de cada um desses 
haplótipos (quatro e dois, respectivamente) impede que essas associações sejam consideradas relevantes.

Adicionalmente, dois outros haplótipos relacionaram-se ao decaimento da função renal. A presença do haplótipo GGCACCGTT associou-se a um maior risco de decaimento da função renal, enquanto a presença do haplótipo TGGATCGCC associouse a um menor risco de decaimento da função renal. Em nossa revisão da literatura, não encontramos estudos avaliando a relação entre o gene AANAT e a função renal.

A enzima AANAT é reconhecida como limitante na síntese de melatonina, e diferentes estudos demonstraram que a síntese hormonal e seu ritmo de secreção são dependentes de variações na expressão dessa proteína $(23,143,144)$. Pagan e cols. demonstraram que a atividade da enzima AANAT associa-se com a concentração de melatonina em grupo de indivíduos portadores de autismo ${ }^{(145)}$ e estudos mostraram associação de SNPs com depressão e câncer de mama ${ }^{(98,99)}$.

Reconhece-se a atuação da melatonina no controle do estresse oxidativo e da inflamação, além dela poder modular o sistema renina-angiotensina-aldosterona (SRAA) e o tônus simpático/parassimpático ${ }^{(86,146-149)}$. Considerando que o estresse oxidativo, a inflamação, o SRAA e a ativação simpática participam na etiopatogênese da DRD ${ }^{(2,150)}$ é plausível supor que variantes no gene que codifica a enzima AANAT possam influenciar a síntese de melatonina e, consequentemente, contribuir para a susceptibilidade ao declínio da função renal no contexto do DM.

Novamente, é importante destacar que o número de indivíduos portadores dos haplótipos é pequeno (30 com haplótipo GGCACCGTT e 66 com haplótipo TGGATCGCC), o que não permite conclusões definitivas. Contudo, trata-se de um achado promissor que merece investigação em populações independentes. 


\subsection{GENE MTNR1A}

O principal achado relacionado ao gene MTNRIA foi a presença do alelo raro A do rs4862705 associar-se a um maior risco para o declínio da função renal nos indivíduos portadores de DM1. Ainda que diversos estudos já tenham relacionado a melatonina a DRD, este é o primeiro estudo mostrando associação entre uma variante em um gene relacionado a melatonina e declínio de função renal em indivíduos com DM. Conforme mencionado anteriormente, a participação da melatonina na modulação do SRAA e do sistema simpático, e seus efeitos anti-inflamatórios e antioxidantes ${ }^{86,}$ 146-149) tornam essa associação plausível.

Parte das ações antioxidantes descritas ocorrem através da via de sinalização da sirtuína 1 (SIRT1), que depende da sinalização intracelular relacionada à ativação do receptor MT1 ${ }^{(151)}$. A ativação desse receptor também se associa a ações antiinflamatórias e anti-apoptóticas da melatonina ${ }^{(152)}$. Além disto, estudos em modelos animais demonstraram que parte dos efeitos que a melatonina exerce sobre o tônus simpático também é mediada pela ativação do MT1, sendo identificada a presença deste receptor em vasos; sua ativação desencadeia resposta de vasoconstrição ${ }^{(153-156)}$.

Ji e cols. avaliaram podócitos de ratos expostos a angiotensina II, para mimetizar um mecanismo de lesão que participa da patogênese da DRD. Esses autores mostraram que a exposição dessas células à melatonina atenuou a geração de ROS, resultando em menor apoptose e restauração da viabilidade celular de maneira dose dependente ${ }^{(86)}$. Deste modo, em teoria, variantes no gene que codifica o receptor de melatonina poderiam reduzir a atuação deste hormônio sobre as células renais, contribuindo para a 
susceptibilidade dos podócitos a lesões causadas pela angiotensina II, a qual tem sua produção aumentada pelas altas concentrações de glicose local ${ }^{(157)}$.

Adicionalmente, Huang e cols., em outro estudo in vitro, mostraram que a presença de albumina foi capaz de reduzir a expressão do receptor MT1 em células tubulares epiteliais ${ }^{(158)}$. Uma vez que as células tubulares epiteliais são comumente expostas a albumina em pacientes com DRD e albuminúria, é possível que, durante a progressão dessa complicação, a diminuição da expressão do receptor MT1 possa contribuir para o dano tubular, uma vez que diminuiriam as ações benéficas da melatonina. Ainda, é possível que esse processo possa estar ainda mais exacerbado em indivíduos com variantes genéticas que modulem a expressão do receptor MT1. Esta hipótese requer confirmação, uma vez que não realizamos e não encontramos na literatura estudos funcionais com as variantes do rs4862705.

Complementarmente à análise do SNP isolado, no estudo de haplótipos, dentre as amplas possibilidades de combinações existentes, um dos haplótipos (CACAGGAA), que contém o alelo raro A do rs4862705, associou-se a um maior risco tanto para a presença de DRD, como para o declínio da função renal. Contudo, a interpretação destes resultados deve ser realizada com cautela, uma vez que o número de indivíduos portadores desse haplótipo é extremamente limitado (sete indivíduos em um grupo e três no outro).

Finalmente, na subanálise que associou a concentração urinária de aMT6s com as variantes genéticas, não se observou diferença significante entre portadores ou não do alelo raro A do SNP rs4862705. Já o grupo de portadores do haplótipo CACAGGA apresentou maior concentração de aMT6s urinária quando comparado aos portadores de outros haplótipos, porém, como previamente mencionado, a interpretação desse achado 
é limitada pelo pequeno número de portadores do haplótipo e pelas limitações metodológicas relacionadas à mensuração das concentrações urinárias de aMT6s já mencionadas.

\subsection{CONCENTRAÇÕES URINÁRIAS DE aMT6s}

A avaliação das concentrações urinárias de aMT6s não evidenciou diferenças entre os indivíduos com e sem DM1 na análise não ajustada, e maiores concentrações de aMT6s foram encontradas no grupo com DM1 após o ajuste para potenciais fatores de confusão. Esse resultado contrastou com aqueles observados em estudos prévios, que evidenciaram menores concentrações de melatonina em crianças, adolescentes e adultos com DM1 ${ }^{(90,92)}$.

No estudo de Amaral e cols., foram recrutados 15 indivíduos com DM1 e nove indivíduos controles sem DM1, sendo que para a avaliação das concentrações de aMT6s urinária versus controle, foram considerados dados de apenas nove dos 15 indivíduos com DM1, selecionados por apresentarem glicemia capilar alterada durante 10 dias. Nesta análise, foram encontrados valores diminuídos de aMT6s nos indivíduos com DM1 em relação ao grupo controle sem DM1. Adicionalmente, esse estudo mostrou uma correlação negativa entre os valores de aMT6s urinária e a glicemia capilar aferida ao longo de 10 dias ${ }^{(90)}$.

Já o trabalho de Kor e cols. selecionou 40 indivíduos com DM1 com mediana de idade 10,4 anos, tempo médio de DM de 2,8 anos e controle glicêmico inadequado (mediana de $\mathrm{HbA} 1 \mathrm{c}$ de $8,78 \%$ ) e mensurou a melatonina sérica (uma medida única entre 8h30 e 9h da manhã), comparando com um grupo de 30 indivíduos sem DM1 da mesma 
faixa etária. O resultado encontrado foi de concentração menor de melatonina sérica no grupo de indivíduos com DM1 ${ }^{(92)}$.

A casuística do presente estudo foi maior que a casuística dos estudos citados acima, além de apresentar características demográficas e clínicas distintas, com média etária superior, maior tempo de DM, proporção significativa de indivíduos com complicações microvasculares $(53,7 \%)$ e com outras comorbidades (como HAS e dislipidemia) e uso de várias medicações. Essas diferenças nas características das populações, bem como diferenças metodológicas entre os estudos indicam a necessidade de estudos adicionais com maior número de indivíduos avaliados e que apresentem diferentes características clínicas relacionadas ao DM, tais como faixa etária, tempo de doença, grau de controle glicêmico e presença de complicações e comorbidades, entre outras.

Não foram encontradas diferenças nas concentrações urinárias de aMT6s entre os portadores e não portadores das diferentes complicações diabéticas analisadas. Não encontramos na literatura outros estudos que tivessem avaliado as concentrações de melatonina em indivíduos com DM1 de acordo com o status das diferentes complicações relacionadas ao DM.

Como já mencionado anteriormente, existem estudos que analisaram as concentrações de melatonina em portadores de DM2. A maioria desses estudos possui uma casuística pequena e eles diferem entre si quanto à metodologia utilizada para a mensuração de melatonina (urinária, sérica, salivar e com diferentes tempos de coletas). A análise dos resultados desses trabalhos não permite conclusões definitivas sobre a associação entre as complicações diabéticas e as concentrações de melatonina no contexto do DM2 ${ }^{(93-96)}$. 
Na subanálise de concentrações urinárias de aMT6s entre os indivíduos com DM1 divididos nos grupos que apresentavam concentração acima ou abaixo da mediana, o grupo com maior concentração de melatonina tinha predomínio de indivíduos do sexo feminino. A diferença na produção e excreção de melatonina entre os sexos já foi previamente estudada, sendo que os dados de concentrações de aMT6s urinária são contraditórios, mas sugerem que o uso de anticoncepcionais orais e as fases hormonais do ciclo feminino interferem na concentração hormonal ${ }^{(159-161)}$. No presente estudo, a fase do ciclo menstrual das participantes não foi avaliada, assim como o uso de anticoncepcionais, dificultando a interpretação desse achado.

As dificuldades técnicas para realização de estudo de concentrações de melatonina em ambiente não controlado são diversas e relevantes para a adequada interpretação dos dados. Como primeira limitação, temos que os dados de concentração urinária de aMT6s são referentes a uma única coleta de urina noturna, o que por si só pode não ser representativo da produção hormonal efetiva. Outra limitação já mencionada refere-se aos fatores que influenciam a produção de melatonina e que não foram avaliados no presente estudo, como a temperatura ambiente, as fases do ciclo menstrual e a duração do período noturno dependente da estação do ano.

Por fim, em nossa amostra, o tempo total de coleta foi avaliado por recordatório individual, sendo que consideramos este como o tempo total, em horas, transcorrido das 19h (início da coleta) até o momento em que o paciente despertou e coletou a primeira urina da manhã (tempo final da coleta). Não sabemos com precisão o tempo total e tampouco o horário da última micção antes das $19 \mathrm{~h}$. Este último fato é um limitante relevante, pois a concentração urinária de aMT6 relaciona-se com o volume total de urina excretado. Assim, a não padronização do início da coleta de urina, com a 
orientação para que o indivíduo esvaziasse completamente sua bexiga, pode alterar o volume total de urina e, assim, interferir na interpretação dos dados encontrados. Os indivíduos com DM1 tiveram um tempo maior de coleta do que os sem DM1, o que pode ser interpretado como maior tempo de sono total, com potencial ausência de exposição à luz. Este fato poderia influenciar a concentração final de aMT6s, justificando uma maior concentração do metabólito da melatonina nos indivíduos com DM1.

Finalmente, consideramos que o presente estudo teve natureza exploratória e estudos adicionais com maiores casuísticas e, idealmente, controlando os fatores confundidores, são necessários para elucidar se indivíduos com DM1 apresentam alterações nas concentrações urinárias de aMT6s e se essas podem ser moduladas pelas complicações crônicas do DM. 


\section{CONCLUSÕES}

1. A presença do alelo raro A do rs4446909 no gene ASMT, que codifica uma das enzimas limitantes da síntese de melatonina, associou-se a um menor risco de RD.

2. A presença dos haplótipos GGCACCGTT e TGGATCGCC no gene AANAT, que codifica uma das enzimas limitantes da síntese de melatonina, associaram-se, respectivamente, a maior e menor risco de declínio da função renal.

3. A presença do alelo raro A do rs4862705 no gene MTNR1A, que codifica o receptor MT1, associou-se a um maior risco de declínio da função renal.

4. Não houve associação das complicações microvasculares com a concentração urinária do principal metabólito da melatonina (aMT6s). 
7 ANEXOS

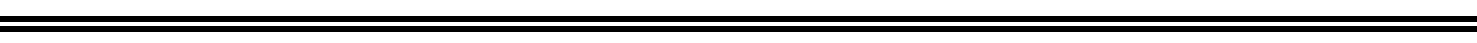




\title{
ANEXO 1
}

\section{PARECER CONSUBSTANCIADO DO CEP}

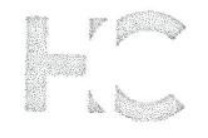

\author{
HOSPITAL DAS CLÍNICAS DA \\ FACULDADE DE MEDICINA DA \\ USP - HCFMUSP
}

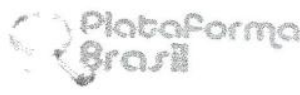

\section{PARECER CONSUBSTANCIADO DO CEP}

\section{DADOS DO PROJETO DE PESQUISA}

Título da Pesquisa: Estudo da Concentração de Melatonina Urinária e de Polimorfismos em Genes que Codificam Receptores de Melatonina e Enzimas da Sintese Hormonal e sua Associação com a Susceptibilidade a Complicações Crônicas em Pacientes Diabéticos
Tipo 1

Pesquisador: Maria Lúcia Cardillo Corrêa Giannella

Área Temática: Genética Humana:

(Trata-se de pesquisa envolvendo Genética Humana que não necessita de análise

Versão: 2 ética por parte da CONEP;);

CAAE: 50483415.5 .0000 .0068

Instituição Proponente: HOSPITAL DAS CLINICAS DA FACULDADE DE MEDIÇINA DA U S P

Patrocinador Principal: FUNDACAO DE AMPARO A PESQUISA DO ESTADO DE SAO PAULO

DADOS DO PARECER

Número do Parecer: 1.511.697

Apresentação do Projeto:

Estudo da Concentração de Melatonina Urinária e de Polimorfismos em Genes que Codificam Receptores de Melatonina e Enzimas da Síntese Hormonal e sua Associação com a Susceptibilidade a Complicações Crônicas em Pacientes Diabéticos Tipo 1. Apresentação adequada, clara e científicamente embasada.

Objetivo da Pesquisa:

Verificar a concentração de melatonina urinária e de polimorfismos em genes que codificam receptores de melatonina e enzimas da síntese hormonal e sua associação com a susceptibilidade a complicações crônicas em pacientes diabéticos tipo 1.

Avaliação dos Riscos e Beneficios:

Riscos:Mínimo: coleta de urina de $24 \mathrm{~h}$ e aplicação de questionário. Benefícios: pesquisa relevante para identificação de fatores genéticos e clínicos para aconselhamento de

prognóstico. Estudo também importante para conhecimento fisiopatológico de doença muito prevalente sequelante. Não há benefício direto para o participante.

Endereço: Rua Ovídio Pires de Campos, $2255^{\circ}$ andar

$\begin{array}{lll}\text { Bairro: Cerqueira Cesar } & \text { CEP: } & 05.403-010\end{array}$

Telefone: (11)2661-7585 Fax: (11)2661-7585

E-mail: cappesq.adm@hc.fm.usp.br 


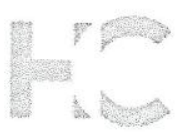

\section{HOSPITAL DAS CLÍNICAS DA \\ FACULDADE DE MEDICINA DA USP - HCFMUSP}

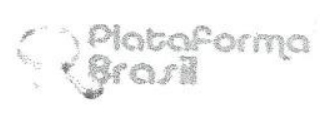

Continuaçẫo do Parecer. 1.511 .697

Comentários e Considerações sobre a Pesquisa:

Resposta do pesquisador aos questionamento do relator CAPPesq. Coment[arios no item abaixo.

Considerações sobre os Termos de apresentação obrigatória:

A pesquisadora apresentou carta frente aos questionamentos do relator. As respostas foram claras, pontuais e esclarecedoras. As dúvidas se pautavam principalmente referente ao banco de material biológico (DNA de células de urina) que é protocolado na CAPPesq tendo como responsável a dra Marcia Nery. É apresentado como banco mas sua descrição se mantém entre repositório (responsabilidade de pessoa da instituição e utilização deste material somente para esta pesquisa) e outros da banco (armazena material também para ser cedido para outras pesquisas). Como a normatização de banco e repositório está em implantação e esta pesquisa utilizará o material somente para esta pesquisa, considero que este ponto não sinaliza infração ética da norma 466/12, e o desenvolvimento da pesquisa deve prosseguir como solicita a pesquisadora.

\section{Recomendações:}

Conclusões ou Pendências e Lista de Inadequações:

Sem pendências.

Considerações Finais a critério do CEP:

: Em conformidade com a Resolução CNS n 466/12 - cabe ao pesquisador: a) desenvolver o projeto conforme delineado; b) elaborar e apresentar relatórios parciais e final; c)apresentar dados solicitados pelo CEP, a qualquer momento; d) manter em arquivo sob sua guarda, por 5 anos da pesquisa, contendo fichas individuais e todos os demais documentos recomendados pelo CEP; e) encaminhar os resultados para publicação, com os devidos créditos aos pesquisadores associados e ao pessoal técnico participante do projeto; f) justificar perante ao CEP interrupção do projeto ou a não publicação dos resultados.

Este parecer foi elaborado baseado nos documentos abaixo relacionados:

\begin{tabular}{|c|c|c|c|c|}
\hline Tipo Documento & Arquivo & Postagem & Autor & Situação \\
\hline $\begin{array}{l}\begin{array}{l}\text { Informações Básicas } \\
\text { do Projeto }\end{array} \\
\end{array}$ & $\begin{array}{l}\text { PB_INFORMAÇŌES_BÁSICAS_DO_P } \\
\text { ROJETO 550933.pdf }\end{array}$ & $\begin{array}{c}05 / 04 / 2016 \\
11: 16: 01\end{array}$ & & Aceito \\
\hline $\begin{array}{l}\text { Recurso Anexado } \\
\text { pelo Pesquisador }\end{array}$ & Carta_CEP.doc & $\begin{array}{c}05 / 04 / 2016 \\
11: 15: 16 \\
\end{array}$ & $\begin{array}{l}\text { Maria Lúcia Cardillo } \\
\text { Corrêa Giannella }\end{array}$ & Aceito \\
\hline $\begin{array}{l}\text { Projeto Detalhado / } \\
\text { Brochura }\end{array}$ & $\begin{array}{l}\text { Projeto_de_Pesquisa_Melatonina_abril1 } \\
\text { 6.docx }\end{array}$ & $\begin{array}{c}05 / 04 / 2016 \\
11: 13: 35 \\
\end{array}$ & $\begin{array}{l}\text { Maria Lúcia Cardillo } \\
\text { Corrêa Giannella }\end{array}$ & Aceito \\
\hline
\end{tabular}

Endereço: Rua Ovídio Pires de Campos, $2255^{\circ}$ andar

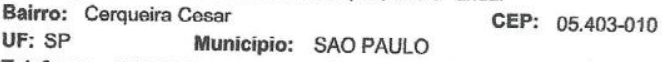

Telefone: (11)2661-7585 Fax: (11)2661-7585 E-mail: cappesq.adm@hc.fm.usp.br 


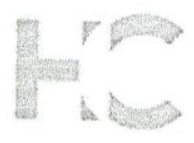

\section{HOSPITAL DAS CLÍNICAS DA FACULDADE DE MEDICINA DA USP - HCFMUSP}

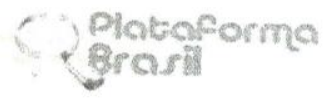

Continuaçăo do Parecer: 1.511.697

\begin{tabular}{|c|c|c|c|c|}
\hline Investigador & $\begin{array}{l}\text { Projeto_de_Pesquisa_Melatonina_abril1 } \\
\text { 6.docx }\end{array}$ & $\begin{array}{c}05 / 04 / 2016 \\
11: 13: 35 \\
\end{array}$ & $\begin{array}{l}\text { Maria Lúcia Cardillo } \\
\text { Corrêa Giannella }\end{array}$ & Aceito \\
\hline Outros & CadastroOnLine.pdf & $\begin{array}{c}27 / 10 / 2015 \\
12: 02: 12 \\
\end{array}$ & $\begin{array}{l}\text { Maria Lúcia Cardillo } \\
\text { Corrêa Giannella }\end{array}$ & Aceito \\
\hline $\begin{array}{l}\text { TCLE / Termos de } \\
\text { Assentimento / } \\
\text { Justificativa de } \\
\text { Ausência } \\
\end{array}$ & TCLE_completo.docx & $\begin{array}{c}13 / 10 / 2015 \\
09: 53: 03\end{array}$ & $\begin{array}{l}\text { Maria Lúcia Cardillo } \\
\text { Corrêa Giannella }\end{array}$ & Aceito \\
\hline Folha de Rosto & folhaatualizada.pdf & $\begin{array}{c}29 / 09 / 2015 \\
16: 03: 33 \\
\end{array}$ & $\begin{array}{l}\text { Maria Lúcia Cardillo } \\
\text { Corrêa Giannella }\end{array}$ & Aceito \\
\hline
\end{tabular}

Situação do Parecer:

Aprovado

Necessita Apreciação da CONEP:

Não

SAO PAULO, 25 de Abril de 2016

Assinado por:

ALFREDO JOSE MANSUR

(Coordenador)

Endereço: Rua Ovidio Pires de Campos, $2255^{\circ}$ andar

Bairro: Cerqueira Cesar

CEP: $05.403-010$

UF: SP

Município: SAO PAULO

Telefone: (11)2661-7585

Fax: (11)2661-7585

E-mail: cappesq.adm@hc.fm.usp.br 


\section{ANEXO 2 \\ TERMO DE CONSENTIMENTO LIVRE E ESCLARECIDO \\ HOSPITAL DAS CLÍNICAS DA FACULDADE DE MEDICINA DA UNIVERSIDADE DE SÃO PAULO-HCFMUSP \\ TERMO DE CONSENTIMENTO LIVRE E ESCLARECIDO}

DADOS DE IDENTIFICAÇÃO DO SUJEITO DA PESQUISA OU RESPONSÁVEL LEGAL

1.NOME:

DOCUMENTO DE IDENTIDADE $n^{\circ}$. : SEXO : M $\square \mathrm{F} \square$ DATA NASCIMENTO: ........................ ENDEREÇO: $n^{\circ}:$ APTO:

BAIRRO: CIDADE:

CEP:. TELEFONE:DDD(......).

2. RESPONSÁVEL LEGAL:

NATUREZA (grau de parentesco, tutor, curador etc.)

DOCUMENTO DE IDENTIDADE $n^{\circ}$.: SEXO: $\mathrm{M} \square \mathrm{F} \square$

DATA NASCIMENTO.: .....................

ENDEREÇO: $n^{\circ}:$ APTO:

BAIRRO: CIDADE:

CEP: TELEFONE: DDD (....)

\section{DADOS SOBRE A PESQUISA}

1. TÍTULO DO PROTOCOLO DE PESQUISA

Estudo da Concentração de Melatonina Urinária e de Polimorfismos em Genes que Codificam Receptores de Melatonina e Enzimas da Síntese Hormonal e sua Associação com a Susceptibilidade a Complicações Crônicas em Pacientes Diabéticos Tipo 1

PESQUISADOR: Dra. Maria Lúcia Cardillo Corrêa-Giannella

CARGO/FUNÇÃO: Médica Assistente e Professora Pesquisadora INSCRIÇÃO CONSELHO REGIONAL N 62926

UNIDADE DO HCFMUSP: Serviço de Endocrinologia do Departamento de Clínica Médica

2. AVALIAÇÃO DO RISCO DA PESQUISA:

$\begin{array}{ll}\text { RISCO MÍNIMO X } & \text { RISCO MÉDIO } \\ \text { RISCO BAIXO } \square & \text { RISCO MAIOR }\end{array}$

3. DURAÇÃO DA PESQUISA: 01/07/2015 a 30/08/2016 


\section{1 - Desenho do estudo e objetivo(s)}

O diabetes melito é uma doença que se caracteriza por aumento da glicemia (açúcar no sangue) e o seu descontrole por um longo tempo pode levar ao desenvolvimento de complicações como diminuição ou perda da visão, problemas nos rins e nos nervos. Assim, o/a Senhor(a) está convidado(a) a participar da nossa pesquisa, que tem como objetivo relacionar o aparecimento de complicações diabéticas (na retina, nos nervos e nos rins) com as diferentes concentrações do hormônio melatonina na urina.

\section{2 - Descrição dos procedimentos que serão realizados, com seus propósitos e identificação dos que forem experimentais e não rotineiros}

Caso o(a) Senhor(a) concorde em participar deste estudo, iremos avaliar a concentração de melatonina na sua urina - urina esta que será coletada ao longo da noite anterior a sua próxima consulta no ambulatório. Da urina que o(a) Senhor(a) coletar, armazenaremos $10 \mathrm{ml}$ para a análise da concentração de melatonina.

\section{3 - Relação dos procedimentos rotineiros e como são realizados - coleta de urina}

Somente será solicitada a coleta de toda urina ao longo de uma noite de domingo, com início as 22 horas. O (A) Senhor(a) deverá armazenar no frasco que lhe foi dado todo o volume de urina que venha a urinar durante à noite, inclusive a primeira urina logo após o seu despertar (esta será a última urina que o (a) Senhor (a) deverá guardar no frasco). O (A) Senhor (a) guardará esse frasco na geladeira durante todo o dia seguinte (segunda-feira) e o trará para entregar ao médico responsável pela pesquisa no dia da sua consulta no Ambulatório de Diabetes do Hospital das Clínicas, na terça-feira.

Além da coleta de urina, o (a) Senhor(a) precisará responder ao médico responsável pela pesquisa perguntas contidas em três questionários, que têm o objetivo de caracterizar como é a saúde do seu sono.

4 - Descrição dos desconfortos e riscos esperados nos procedimentos dos itens 2 e 3

Não há risco ou desconforto esperado.

\section{5 - Benefícios para o participante}

Não há benefício direto para o participante. Existe a possibilidade de que após a realização desse estudo, sejam identificados fatores genéticos e clínicos que aumentem 
o risco para o desenvolvimento das complicações associadas ao diabetes. Com isso, no futuro, poderemos diagnosticar e tratar com precisão os portadores de diabetes, identificar em familiares os que têm risco de ter diabetes e indicar a prioridade para futuras estratégias de prevenção e de controle intensivo dos portadores de diabetes com maior risco de desenvolver essas doenças associadas.

\section{6 - Relação de procedimentos alternativos que possam ser vantajosos, pelos quais o paciente pode optar}

Como a coleta de urina não é um procedimento para tratamento, não há procedimentos alternativos que possam ser vantajosos para o(a) Senhor(a), caso o Senhor (a) opte por não coletar a urina.

\section{7 - Garantia de acesso}

Em qualquer etapa do estudo, o (a) Senhor(a) terá acesso aos profissionais responsáveis pela pesquisa para esclarecimento de eventuais dúvidas. O principal investigador é a Dra. Maria Lúcia Cardillo Corrêa-Giannella; Telefone(s) 3061-7253, ramal 13. Se você tiver alguma consideração ou dúvida sobre a ética da pesquisa, entre em contato com o Comitê de Ética em Pesquisa (CEP) - Rua Ovídio Pires de Campos, 225 - 5o andar - tel: 2661-6442 ramais 16, 17, 18 - e-mail: cappesq.adm@hc.fm.usp.br

8 - O (A) Senhor (a) tem liberdade para retirar seu consentimento a qualquer momento e de deixar de participar do estudo, sem que isto traga prejuízo à continuidade da assistência médica que o Senhor (a) recebe no Hospital das Clínicas.

9 - Direito de confidencialidade: Todos os dados obtidos, tais como: resultados de exames e testes, bem como do prontuário, somente serão acessíveis aos pesquisadores envolvidos e não será permitido o acesso a terceiros (seguradoras, empregadores, supervisores hierárquicos etc.), de forma a impedir qualquer tipo de discriminação e/ou estigmatização, individual ou coletiva no caso de resultados indicativos de desenvolvimento de diabetes ou de suas complicações. As informações obtidas serão analisadas em conjunto com outros pacientes, não sendo divulgada a identificação de nenhum paciente.

10 - O (A) $\mathrm{Sr}$ (a) tem o direito de ser mantido atualizado sobre os resultados parciais das pesquisas; 
11 - Despesas e compensações: não há despesas pessoais para o participante em qualquer fase do estudo, incluindo exames e consultas. Também não há compensação financeira relacionada à sua participação. Se existir qualquer despesa adicional, ela será absorvida pelo orçamento da pesquisa. Todos os procedimentos necessários para o estudo serão realizados no dia de sua consulta. Caso haja despesas adicionais com transporte e alimentação, por necessidade de comparecimento ao ambulatório fora do dia da sua consulta, serão ressarcidas.

12 - Compromisso do pesquisador de utilizar os dados e o material coletado em outras pesquisas apenas com autorização do paciente

A amostra de urina cedida pelo(a) $\operatorname{Sr}($ a) apenas será utilizada nesta pesquisa.

Há necessidade de consultá-lo para autorizar o uso deste material doado em outras pesquisas científicas?

Não se aplica.

Acredito ter sido suficientemente informado a respeito das informações que li ou que foram lidas para mim, descrevendo o projeto de pesquisa "Estudo da Concentração de Melatonina Urinária e de Polimorfismos em Genes que Codificam Receptores de Melatonina e Enzimas da Síntese Hormonal e sua Associação com a Susceptibilidade a Complicações Crônicas em Pacientes Diabéticos Tipo 1."

Eu discuti com a Dra. Maria Lúcia Cardillo Corrêa Giannella sobre a minha decisão em participar nesse estudo. Ficaram claros para mim quais são os propósitos do estudo, os procedimentos a serem realizados, seus desconfortos e riscos, as garantias de confidencialidade e de esclarecimentos permanentes. Ficou claro também, que minha participação é isenta de despesas e que tenho garantia do acesso a tratamento hospitalar quando necessário. Concordo voluntariamente em participar deste estudo e poderei retirar o meu consentimento a qualquer momento, antes ou durante o mesmo, sem penalidades ou prejuízo ou perda de qualquer benefício que eu possa ter adquirido, ou no meu atendimento neste Serviço. 
Assinatura do paciente/representante legal Data

$1 /$

Assinatura da testemunha

Data $1 / 1$

para casos de pacientes menores de 18 anos, analfabetos, semi-analfabetos ou portadores de deficiência auditiva ou visual.

\section{(Somente para o responsável do projeto)}

Declaro que obtive de forma apropriada e voluntária o Consentimento Livre e Esclarecido deste paciente ou representante legal para a participação neste estudo. 


\section{ANEXO 3 \\ ESCALA DE SONOLÊNCIA DE EPPWORTH (ESS-BR)}

NOME:

DATA: IDADE: SEXO:

Qual a probabilidade de você cochilar ou dormir, e não apenas se sentir cansado nas seguintes situações? Considere o modo de vida que você tem levado recentemente. Mesmo que você não tenha feito algumas destas coisas recentemente, tente imaginar como elas o afetaria. Escolha o número mais apropriado para responder cada questão:

$0=$ nunca cochilaria

1= pequena probabilidade de cochilar

2- probabilidade média de cochilar

3- grande probabilidade de cochilar

Situação

Sentando e lendo

Assistindo TV

Sentado, quieto, em um lugar público

(por exemplo, em um teatro, reunião ou palestra)

Andando de carro por uma hora sem parar.

como passageiro

Ao deitar-se à tarde para descansar.

quando possível

Sentando conversando com alguém

Sentando quieto após o almoço sem bebida de álcool

Em um carro parado no trânsito por alguns minutos

\section{Probabilidade de cochilar}

$\begin{array}{llll}0 & 1 & 2 & 3\end{array}$

$\begin{array}{llll}0 & 1 & 2 & 3\end{array}$

$\begin{array}{llll}0 & 1 & 2 & 3\end{array}$

$\begin{array}{llll}0 & 1 & 2 & 3\end{array}$

$\begin{array}{llll}0 & 1 & 2 & 3\end{array}$

$\begin{array}{llll}0 & 1 & 2 & 3\end{array}$

$\begin{array}{llll}0 & 1 & 2 & 3\end{array}$

$\begin{array}{llll}0 & 1 & 2 & 3\end{array}$

\section{Obrigado por sua cooperação}




\section{ESCALA DE SONO DE PITTSBURGH (PSQI-BR)}

NOME:

DATA:

IDADE:

SEXO:

\section{Instruções:}

As seguintes perguntas são relativas aos seus hábitos usuais de sono durante o último mês somente, suas respostas devem indicar a lembrança mais exata da maioria dos dias e noites no último mês. Por favor, responda a todas as perguntas:

1. Durante o último mês quando você geralmente foi para a cama à noite

Hora usual de deitar:

2. Durante o último mês, quanto tempo (em minutos) você geralmente levou para dormir à noite?

3. Durante o último mês, quando você geralmente levantou de manhã?

4. Durante o último mês, quantas horas de sono você teve por noite? (Esta pode ser diferente de horas que você ficou na cama).

Para cada uma das questões restantes, marque a melhor (uma) resposta. Por favor responde a todas as questões.

5. Durante o último mês, com que frequência você teve dificuldade de dormir porque você...

a. Não conseguiu adormecer em até 30 minutos:

Nenhuma no último mês ( )

Menos de $1 \mathrm{vez} / \mathrm{semana}($ )

1 ou 2 vezes/ semana ( )

3 ou mais vezes/semana ( )

b. Acordou no meio da noite ou de manhã cedo:

Nenhuma no último mês ( )

Menos de $1 \mathrm{vez} / \mathrm{semana}($ )

1 ou 2 vezes/ semana ( )

3 ou mais vezes/semana ( )

c. Precisou levantar para ir ao banheiro:

Nenhuma no último mês ( )

Menos de $1 \mathrm{vez} / \mathrm{semana}($ )

1 ou 2 vezes/ semana ( )

3 ou mais vezes/semana ( ) 
d. Não conseguiu respirar confortavelmente:

Nenhuma no último mês ( )

Menos de $1 \mathrm{vez} / \mathrm{semana}($ )

1 ou 2 vezes/ semana ( )

3 ou mais vezes/semana ( )

e. Tossiu ou roncou forte:

Nenhuma no último mês ( )

Menos de $1 \mathrm{vez} / \mathrm{semana}($ )

1 ou 2 vezes/ semana ( )

3 ou mais vezes/semana ( )

f. Sentiu muito frio:

Nenhuma no último mês ( )

Menos de $1 \mathrm{vez} / \mathrm{semana}($ )

1 ou 2 vezes/ semana ( )

3 ou mais vezes/semana ( )

g. Sentiu muito calor:

Nenhuma no último mês ( )

Menos de 1 vez/semana ( )

1 ou 2 vezes/ semana ( )

3 ou mais vezes/semana ( )

h. Teve sonhos ruins:

Nenhuma no último mês ( )

Menos de 1 vez/semana ( )

1 ou 2 vezes/ semana ( )

3 ou mais vezes/semana ( )

i. Teve dor:

Nenhuma no último mês ( )

Menos de 1 vez/semana ( )

1 ou 2 vezes/ semana ( )

3 ou mais vezes/semana ( )

j. Outra(s) Razão(ões), por favor descreva 
Com que frequência durante o último mês, você teve dificuldade para dormir devido a esta razão:

Nenhuma no último mês ( )

Menos de $1 \mathrm{vez} / \mathrm{semana}($ )

1 ou 2 vezes/ semana ( )

3 ou mais vezes/semana ( )

6. Durante o último mês, com você classificaria a qualidade do seu sono de uma maneira geral?
Muito boa ( )
Boa ( )
Ruim ( )
Muito ruim ( )

7. Durante o último mês, com que frequência você tomou medicamento (prescrito ou "por conta própria") para lhe ajudar a dormir?

Nenhuma no último mês ( )

Menos de 1 vez/semana ( )

1 ou 2 vezes/ semana ( )

3 ou mais vezes/ semana ( )

8. No último mês, com que frequência você teve dificuldade ficar acordado enquanto dirigia, comia ou participava de uma atividade social (festa, reunião de amigos, trabalho, estudo)?

Nenhuma no último mês ( )

Menos de $1 \mathrm{vez} / \mathrm{semana}(\mathrm{)}$

1 ou 2 vezes/ semana ( )

3 ou mais vezes/semana ( )

9. Durante o último mês. Quão problemático foi para você manter o entusiasmo (ânimo) para fazer as coisas (suas atividades habituais)?

Nenhuma dificuldade ( )

Um problema muito leve ( )

Um problema razoável ( )

Um problema muito grande ( ) 
10. Você tem um (a) parceiro(a)/esposo (a) ou colega de quarto?

Não ( )

Parceiro ou colega, mas em outro quarto ( )

Parceiro ou mesmo quarto, mas não na mesma cama ( )

Parceiro na mesma cama ( )

Se você tem um parceiro ou colega de quarto pergunte a ele/ela com que frequência no último mês você teve:

a. Ronco forte?

Nenhuma no último mês ( )

Menos de $1 \mathrm{vez} / \mathrm{semana}(\mathrm{)}$

1 ou 2 vezes/ semana ( )

3 ou mais vezes/semana ( )

b. Longas paradas na respiração enquanto dormia

Nenhuma no último mês ( )

Menos de $1 \mathrm{vez} / \mathrm{semana}$ ( )

1 ou 2 vezes/ semana ( )

3 ou mais vezes/semana ( )

c. Contrações ou puxões na perna enquanto você dormia

Nenhuma no último mês ( )

Menos de $1 \mathrm{vez} / \mathrm{semana}(\mathrm{)}$

1 ou 2 vezes/ semana ( )

3 ou mais vezes/semana ( )

d. Episódios de desorientação ou confusão durante o sono

Nenhuma no último mês ( )

Menos de $1 \mathrm{vez} / \mathrm{semana}(\mathrm{)}$

1 ou 2 vezes/ semana ( )

3 ou mais vezes/semana ( )

e. Outra alterações (inquietações) enquanto você dorme; por favor, descreva:

Nenhuma no último mês ( )

Menos de $1 \mathrm{vez} / \mathrm{semana}$ ( )

1 ou 2 vezes/ semana ( )

3 ou mais vezes/semana ( ) 


\section{ANEXO 4 \\ QUESTIONÁRIO DO SONO}

1) Quais medicações o $\operatorname{Sr}(a)$ está em uso regular atualmente?

2) Está em uso das seguintes classes de medicações? (assinalar com $X$ )
a. I.E.C.A
b. Beta-bloqueador
c. Bloqueador do Canal De Cálcio
d. Inibidor de Recaptação de Serotonina
e. Hipnóticos (ex. Hemitartarato de Zolpidem)
f. Benzodiazepínicos
g. Estatinas
h. AAS

3) Qual o nível da última hemoglobina glicada? $\%$ Data:

4) Qual é seu horário de trabalho cotidiano? (considerando início da atividade)
a. Manhã (6h-12h)
b. Tarde (13-19h)
c. Noturno (20h-05h)
d. Variável (incluindo noturno) Neste caso qual a periodicidade do trabalho noturno(x/semana)

5) Na noite da coleta da urina que horas o $\mathrm{Sr}(\mathrm{a})$ acendeu as luzes de sua casa/quarto? 
6) Na noite da coleta da urina o $\operatorname{Sr}(a)$ assistiu televisão? Se sim, por quanto tempo (em horas)? E que horas (aproximadamente) parou a utilização?

7) $\mathrm{Na}$ noite da coleta da urina o $\mathrm{Sr}$ (a) utilizou computador? Se sim por quanto tempo (em horas)? E que horas (aproximadamente) parou a utilização?

8) $\mathrm{Na}$ noite da coleta da urina o $\mathrm{Sr}(\mathrm{a})$ utilizou celular para ler mensagem/email/acessar a internet? Se sim por quanto tempo (em horas)? E que horas (aproximadamente) parou a utilização?

9) $\mathrm{Na}$ noite da coleta da urina o $\mathrm{Sr}$ (a) utilizou algum tablet para ler mensagem/email/acessar a internet? Se sim por quanto tempo (em horas)? E que horas (aproximadamente) parou a utilização?

10) Na noite da coleta da urina o $\operatorname{Sr}($ a) despertou e se levantou da cama quantas vezes?
a. Nenhuma
b. Uma vez
c. Duas vezes
d. Três vezes
e. Quatro ou mais vezes

11) Na noite da coleta da urina o $\operatorname{Sr}($ a) despertou e acendeu as luzes quantas vezes?
a. Nenhuma
b. Uma vez
c. Duas vezes
d. Três vezes
e. Quatro ou mais vezes

12) Por quanto tempo as luzes permaneceram acessas (tempo máximo estimado do maior episódio)?
a. Menos de um minuto
b. De um minuto a três minutos
c. De três a dez minutos
d. Mais de dez minutos 
13) Qual o tipo de lâmpada que o $\operatorname{Sr}(a)$ acendeu em casa na noite da coleta?
a. Fluorescente (PL)
b. Incandescência (Amarela)
c. Lâmpada de LED
d. Outras. Especificar:

\section{Exemplos de lâmpadas:}

a. Fluorescente (PL)

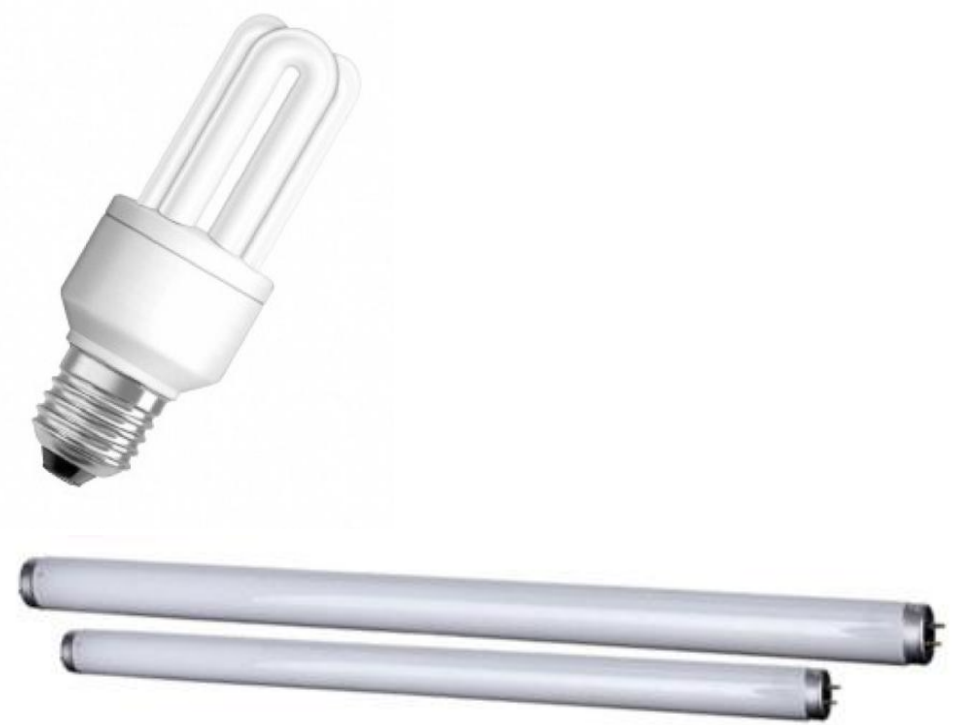

b. Incandescente (Amarela)

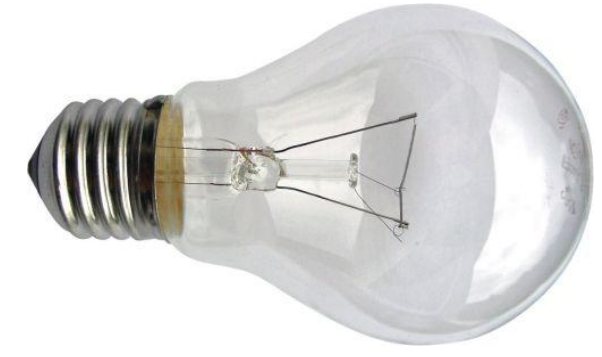

c. LED

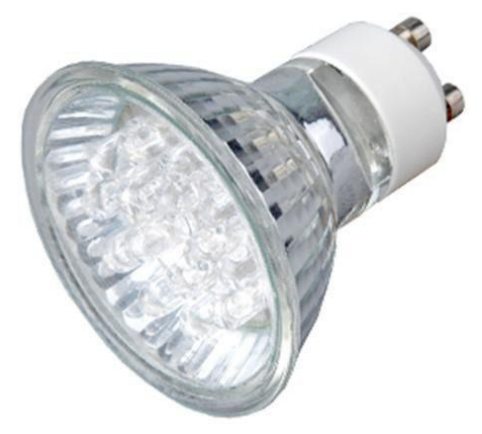




\section{ANEXO 5}

\section{GENE ASMT}

Tabela 1 - Frequência dos genótipos dos polimorfismos no gene ASMT de acordo com a ausência ou presença de neuropatia periférica (NP)

\begin{tabular}{lcccc}
\hline & Ausência de NP & Presença de NP & OR (IC 95\%) & Valor de $\boldsymbol{P}$ \\
\hline $\mathbf{N}$ & 181 & 101 & & \\
$\boldsymbol{A S M T}$ & & & $0,72(0,38-1,38)$ & 0,3423 \\
rs6588810 & & 0,003 & & \\
AA & 0,006 & 0,168 & & \\
AG & 0,229 & 0,802 & & \\
GG & 0,765 & 0,113 & $1,10(0,70-1,72)$ & 0,6737 \\
MAF & 0,120 & & & \\
rs4446909 & & 0,099 & & \\
AA & 0,050 & 0,288 & & \\
AG & 0,309 & 0,613 & & \\
GG & 0,641 & 0,242 & & \\
MAF & 0,204 & &
\end{tabular}

MAF: frequência do alelo raro; OR: Odds ratio; IC: intervalo de confiança; OR para o alelo raro em um modelo codominante de regressão logística ajustada para idade, tempo de DM, presença de HAS, triglicérides, TFGe, uso de inibidores da enzima conversora da angiotensina e uso de estatina. $P \leq 0,025$ foi considerado significante.

Tabela 2 - Frequência dos genótipos dos polimorfismos no gene ASMT de acordo com a ausência ou presença de neuropatia autonômica cardiovascular (NAC)

\begin{tabular}{lcccc}
\hline & Ausência de NAC & Presença de NAC & OR (IC 95\%) & Valor de $\boldsymbol{P}$ \\
\hline $\mathbf{N}$ & 206 & 85 & & \\
$\boldsymbol{A S M T}$ & & & $1,29(0,70-2,34)$ & 0,4041 \\
rs6588810 & & & & \\
$\quad$ AA & 0,010 & 0,024 & & \\
AG & 0,201 & 0,250 & & \\
GG & 0,789 & 0,726 & 0,60739 \\
MAF & 0,110 & 0,148 & & \\
rs4446909 & & & & \\
AA & 0,073 & 0,059 & & \\
AG & 0,286 & 0,306 & & \\
GG & 0,641 & 0,635 & & \\
MAF & 0,216 & 0,211 & & \\
\hline
\end{tabular}

MAF: frequência do alelo raro; OR: Odds ratio; IC: intervalo de confiança; OR para o alelo raro em um modelo codominante de regressão logística ajustada para presença de HAS, TFGe, triglicérides e HbAlc. $P \leq 0,025$ foi considerado significante. 
Tabela 3 - Frequência dos genótipos dos polimorfismos no gene ASMT de acordo com a ausência ou presença de doença renal diabética (DRD)

\begin{tabular}{|c|c|c|c|c|}
\hline & Ausência de DRD & Presença de DRD & OR (IC 95\%) & Valor de $P$ \\
\hline $\mathbf{N}$ & 332 & 153 & & \\
\hline \multicolumn{5}{|l|}{$A S M T$} \\
\hline rs6588810 & & & $1,39(0,86-2,24)$ & 0,1665 \\
\hline AA & 0,012 & 0,020 & & \\
\hline AG & 0,189 & 0,237 & & \\
\hline GG & 0,799 & 0,743 & & \\
\hline MAF & 0,106 & 0,138 & & \\
\hline rs4446909 & & & $0,87(0,60-1,24)$ & 0,4536 \\
\hline AA & 0,054 & 0,059 & & \\
\hline AG & 0,310 & 0,268 & & \\
\hline GG & 0,636 & 0,673 & & \\
\hline MAF & 0,209 & 0,192 & & \\
\hline
\end{tabular}

MAF: frequência do alelo raro; OR: Odds ratio; IC: intervalo de confiança; OR para o alelo raro em um modelo codominante de regressão logística ajustada para idade, IMC, tempo de DM, presença de HAS, triglicérides e uso de estatina. $P \leq 0,025$ foi considerado significante.

Tabela 4 - Frequência dos genótipos dos polimorfismos no gene ASMT de acordo com o status do declínio da função renal

\begin{tabular}{lcccc}
\hline & Não Declinante & Declinante & OR (IC 95\%) & Valor de $\boldsymbol{P}$ \\
\hline $\mathbf{N}$ & 312 & 144 & & \\
$\boldsymbol{A S M T}$ & & & $0,94(0,48-1,77)$ & 0,8730 \\
rs6588810 & & & & \\
$\quad$ AA & 0,013 & 0,010 & & \\
AG & 0,195 & 0,217 & & \\
GG & 0,792 & 0,773 & $1,01(0,61-1,63)$ & 0,9424 \\
$\quad$ MAF & 0,110 & 0,118 & & \\
rs446909 & & & & \\
AA & 0,067 & 0,040 & & \\
AG & 0,289 & 0,323 & & \\
GG & 0,644 & 0,637 & & \\
MAF & 0,211 & 0,202 & & \\
\hline
\end{tabular}

MAF: frequência do alelo raro; OR: Odds ratio; IC: intervalo de confiança; OR para o alelo raro em um modelo codominante de regressão logística ajustada para presença de HAS, triglicérides, TFGe e LDL na fase basal. $P \leq$ 0,025 foi considerado significante. 


\section{Gene $A A N A T$}

Tabela 5 - Frequência dos genótipos dos polimorfismos no gene AANAT de acordo com a ausência ou presença de retinopatia diabética (RD)

\begin{tabular}{|c|c|c|c|c|}
\hline & Ausência de RD & Presença de RD & OR (IC 95\%) & Valor de $P$ \\
\hline $\mathbf{N}$ & 129 & 266 & & \\
\hline \multicolumn{5}{|l|}{ AANAT } \\
\hline rs3760138 & & & $0,81(0,57-1,15)$ & 0,2468 \\
\hline GG & 0,258 & 0,312 & & \\
\hline GT & 0,563 & 0,494 & & \\
\hline TT & 0,179 & 0,194 & & \\
\hline MAF & 0,460 & 0,441 & & \\
\hline rs8150 & & & $0,90(0,62-1,33)$ & 0,6207 \\
\hline $\mathrm{CC}$ & 0,087 & 0,110 & & \\
\hline CG & 0,435 & 0,410 & & \\
\hline GG & 0,478 & 0,480 & & \\
\hline MAF & 0,304 & 0,315 & & \\
\hline rs3826287 & & & $1,00(0,69-1,43)$ & 0,9983 \\
\hline $\mathrm{CC}$ & 0,147 & 0,173 & & \\
\hline CG & 0,535 & 0,526 & & \\
\hline GG & 0,318 & 0,301 & & \\
\hline MAF & 0,414 & 0,436 & & \\
\hline rs12946216 & & & $1,25(0,88-1,77)$ & 0,1970 \\
\hline AA & 0,326 & 0,271 & & \\
\hline $\mathrm{AC}$ & 0,465 & 0,530 & & \\
\hline $\mathrm{CC}$ & 0,209 & 0,199 & & \\
\hline MAF & 0,441 & 0,464 & & \\
\hline rs4789300 & & & $1,05(0,75-1,48)$ & 0,7445 \\
\hline $\mathrm{CC}$ & 0,264 & 0,240 & & \\
\hline CT & 0,480 & 0,503 & & \\
\hline TT & 0,256 & 0,255 & & \\
\hline MAF & 0,503 & 0,492 & & \\
\hline rs7210907 & & & $1,38(0,89-2,21)$ & 0,1396 \\
\hline $\mathrm{CC}$ & 0,675 & 0,620 & & \\
\hline CG & 0,302 & 0,342 & & \\
\hline GG & 0,023 & 0,038 & & \\
\hline MAF & 0,173 & 0,208 & & \\
\hline rs12452844 & & & $1,04(0,73-1,49)$ & 0,8161 \\
\hline AA & 0,078 & 0,075 & & \\
\hline AG & 0,480 & 0,417 & & \\
\hline GG & 0,442 & 0,508 & & \\
\hline MAF & 0,317 & 0,283 & & \\
\hline rs12945905 & & & $1,01(0,68-1,49)$ & 0,9575 \\
\hline $\mathrm{CC}$ & 0,721 & 0,714 & & \\
\hline $\mathrm{CT}$ & 0,232 & 0,256 & & \\
\hline TT & 0,047 & 0,030 & & \\
\hline MAF & 0,162 & 0,157 & & \\
\hline rs12951513 & & & $0,93(0,52-1,66)$ & 0,8071 \\
\hline $\mathrm{CC}$ & 0,814 & 0,819 & & \\
\hline $\mathrm{CT}$ & 0,170 & 0,170 & & \\
\hline TT & 0,016 & 0,011 & & \\
\hline MAF & 0,100 & 0,095 & & \\
\hline
\end{tabular}

MAF: frequência do alelo raro; OR: Odds ratio; IC: intervalo de confiança; OR para o alelo raro em um modelo codominante de regressão logística ajustada para idade, tempo de DM, presença de HAS, TFGe, uso de inibidores da enzima conversora da angiotensina, uso de bloqueadores do receptor de angiotensina e uso de estatina. $P \leq 0,005$ foi considerado significante. 
Tabela 6 - Frequência dos genótipos dos polimorfismos no gene AANAT de acordo com a ausência ou presença de neuropatia periférica (NP)

\begin{tabular}{|c|c|c|c|c|}
\hline & Ausência de NP & Presença de NP & OR (IC 95\%) & Valor de $P$ \\
\hline$\overline{\mathbf{N}}$ & 181 & 101 & & \\
\hline \multicolumn{5}{|l|}{$A A N A T$} \\
\hline rs3760138 & & & $0,80(0,53-1,21)$ & 0,3047 \\
\hline GG & 0,282 & 0,346 & & \\
\hline GT & 0,536 & 0,475 & & \\
\hline TT & 0,182 & 0,179 & & \\
\hline MAF & 0,450 & 0,415 & & \\
\hline rs8150 & & & $0,91(0,57-1,43)$ & 0,6871 \\
\hline $\mathrm{CC}$ & 0,101 & 0,108 & & \\
\hline CG & 0,402 & 0,430 & & \\
\hline GG & 0,487 & 0,462 & & \\
\hline MAF & 0,310 & 0,322 & & \\
\hline rs3826287 & & & $0,83(0,54-1,27)$ & 0,4076 \\
\hline $\mathrm{CC}$ & 0,155 & 0,158 & & \\
\hline CG & 0,541 & 0,495 & & \\
\hline GG & 0,304 & 0,347 & & \\
\hline MAF & 0,425 & 0,405 & & \\
\hline rs12946216 & & & $1,45(0,96-2,20)$ & 0,0759 \\
\hline AA & 0,320 & 0,247 & & \\
\hline $\mathrm{AC}$ & 0,491 & 0,495 & & \\
\hline $\mathrm{CC}$ & 0,189 & 0,258 & & \\
\hline MAF & 0,433 & 0,504 & & \\
\hline rs4789300 & & & $1,33(0,59-3,03)$ & 0,4786 \\
\hline $\mathrm{CC}$ & 0,249 & 0,238 & & \\
\hline CT & 0,481 & 0,524 & & \\
\hline TT & 0,270 & 0,238 & & \\
\hline MAF & 0,488 & 0,500 & & \\
\hline rs7210907 & & & $0,95(0,56-1,61)$ & 0,8709 \\
\hline $\mathrm{CC}$ & 0,652 & 0,653 & & \\
\hline CG & 0,326 & 0,307 & & \\
\hline GG & 0,022 & 0,040 & & \\
\hline MAF & 0,185 & 0,193 & & \\
\hline rs12452844 & & & $1,30(0,82-2,07)$ & 0,2571 \\
\hline $\mathrm{AA}$ & 0,066 & 0,089 & & \\
\hline $\mathrm{AG}$ & 0,470 & 0,465 & & \\
\hline GG & 0,464 & 0,446 & & \\
\hline MAF & 0,301 & 0,321 & & \\
\hline rs12945905 & & & $0,87(0,49-1,53)$ & 0,6502 \\
\hline $\mathrm{CC}$ & 0,713 & 0,743 & & \\
\hline CT & 0,243 & 0,247 & & \\
\hline $\mathrm{TT}$ & 0,044 & 0,010 & & \\
\hline MAF & 0,165 & 0,133 & & \\
\hline rs12951513 & & & $0,77(0,36-1,57)$ & 0,4924 \\
\hline $\mathrm{CC}$ & 0,807 & 0,841 & & \\
\hline CT & 0,182 & 0,159 & & \\
\hline TT & 0,011 & 0,000 & & \\
\hline MAF & 0,102 & 0,079 & & \\
\hline
\end{tabular}

MAF: frequência do alelo raro; OR: Odds ratio; IC: intervalo de confiança; OR para o alelo raro em um modelo codominante de regressão logística ajustada para idade, tempo de DM, presença de HAS, triglicérides, TFGe, uso de inibidores da enzima conversora da angiotensina e uso de estatina. $P \leq 0,005$ foi considerado significante. 
Tabela 7 - Frequência dos genótipos dos polimorfismos no gene AANAT de acordo com a ausência ou presença de neuropatia autonômica cardiovascular (NAC)

\begin{tabular}{|c|c|c|c|c|}
\hline & Ausência de NAC & Presença de NAC & OR (IC 95\%) & Valor de $P$ \\
\hline$\overline{\mathbf{N}}$ & 206 & 85 & & \\
\hline \multicolumn{5}{|l|}{$A A N A T$} \\
\hline rs3760138 & & & $1,04(0,69-1,58)$ & 0,8262 \\
\hline GG & 0,311 & 0,306 & & \\
\hline GT & 0,519 & 0,529 & & \\
\hline TT & 0,170 & 0,165 & & \\
\hline MAF & 0,429 & 0,429 & & \\
\hline rs8150 & & & $1,05(0,68-1,61)$ & 0,6166 \\
\hline $\mathrm{CC}$ & 0,119 & 0,120 & & \\
\hline CG & 0,383 & 0,427 & & \\
\hline GG & 0,498 & 0,453 & & \\
\hline MAF & 0,310 & 0,333 & & \\
\hline rs3826287 & & & $1,13(0,74-1,73)$ & 0,5509 \\
\hline $\mathrm{CC}$ & 0,155 & 0,168 & & \\
\hline CG & 0,520 & 0,519 & & \\
\hline GG & 0,325 & 0,306 & & \\
\hline MAF & 0,415 & 0,429 & & \\
\hline rs12946216 & & & $1,25(0,84-1,86)$ & 0,2651 \\
\hline $\mathrm{AA}$ & 0,301 & 0,235 & & \\
\hline $\mathrm{AC}$ & 0,490 & 0,518 & & \\
\hline $\mathrm{CC}$ & 0,209 & 0,247 & & \\
\hline MAF & 0,453 & 0,505 & & \\
\hline rs4789300 & & & $0,78(0,52-1,16)$ & 0,2314 \\
\hline $\mathrm{CC}$ & 0,267 & 0,212 & & \\
\hline CT & 0,495 & 0,494 & & \\
\hline TT & 0,238 & 0,294 & & \\
\hline MAF & 0,514 & 0,458 & & \\
\hline rs7210907 & & & $1,57(0,93-2,64)$ & 0,0863 \\
\hline $\mathrm{CC}$ & 0,685 & 0,565 & & \\
\hline CG & 0,291 & 0,400 & & \\
\hline GG & 0,024 & 0,035 & & \\
\hline MAF & 0,169 & 0,235 & & \\
\hline rs12452844 & & & $1,39(0,89-2,19)$ & 0,1468 \\
\hline AA & 0,068 & 0,082 & & \\
\hline $\mathrm{AG}$ & 0,447 & 0,518 & & \\
\hline GG & 0,485 & 0,400 & & \\
\hline MAF & 0,291 & 0,341 & & \\
\hline rs12945905 & & & $0,70(0,38-1,24)$ & 0,2300 \\
\hline $\mathrm{CC}$ & 0,704 & 0,788 & & \\
\hline CT & 0,262 & 0,188 & & \\
\hline TT & 0,034 & 0,024 & & \\
\hline MAF & 0,165 & 0,117 & & \\
\hline rs12951513 & & & $0,47(0,19-1,04)$ & 0,0639 \\
\hline $\mathrm{CC}$ & 0,786 & 0,882 & & \\
\hline CT & 0,204 & 0,118 & & \\
\hline TT & 0,010 & 0,00 & & \\
\hline MAF & 0,111 & 0,058 & & \\
\hline
\end{tabular}

MAF: frequência do alelo raro; OR: Odds ratio; IC: intervalo de confiança; OR para o alelo raro em um modelo codominante de regressão logística ajustada para presença de HAS, TFGe, triglicérides e HbA1c. $P \leq 0,005$ foi considerado significante. 
Tabela 8 - Frequência dos genótipos dos polimorfismos no gene AANAT de acordo com a ausência ou presença de doença renal diabética (DRD)

\begin{tabular}{|c|c|c|c|c|}
\hline & Ausência de DRD & Presença de DRD & OR (IC 95\%) & Valor de $P$ \\
\hline$\overline{\mathbf{N}}$ & 332 & 153 & & \\
\hline \multicolumn{5}{|l|}{$A A N A T$} \\
\hline rs3760138 & & & $0,91(0,66-1,24)$ & 0,5564 \\
\hline GG & 0,261 & 0,327 & & \\
\hline GT & 0,526 & 0,453 & & \\
\hline TT & 0,213 & 0,220 & & \\
\hline MAF & 0,475 & 0,446 & & \\
\hline rs8150 & & & $1,21(0,86-1,70)$ & 0,2531 \\
\hline $\mathrm{CC}$ & 0,088 & 0,136 & & \\
\hline CG & 0,426 & 0,378 & & \\
\hline GG & 0,486 & 0,486 & & \\
\hline MAF & 0,300 & 0,325 & & \\
\hline rs3826287 & & & $1,31(0,95-1,80)$ & 0,0972 \\
\hline $\mathrm{CC}$ & 0,133 & 0,229 & & \\
\hline CG & 0,557 & 0,470 & & \\
\hline GG & 0,310 & 0,301 & & \\
\hline MAF & 0,411 & 0,464 & & \\
\hline rs12946216 & & & $1,25(0,92-1,70)$ & 0,1503 \\
\hline AA & 0,310 & 0,301 & & \\
\hline $\mathrm{AC}$ & 0,497 & 0,464 & & \\
\hline $\mathrm{CC}$ & 0,193 & 0,235 & & \\
\hline MAF & 0,441 & 0,467 & & \\
\hline rs4789300 & & & $1,37(1,01-1,88)$ & 0,0411 \\
\hline $\mathrm{CC}$ & 0,214 & 0,294 & & \\
\hline CT & 0,512 & 0,458 & & \\
\hline TT & 0,274 & 0,248 & & \\
\hline MAF & 0,469 & 0,522 & & \\
\hline rs7210907 & & & $1,22(0,83-1,79)$ & 0,2998 \\
\hline $\mathrm{CC}$ & 0,642 & 0,614 & & \\
\hline CG & 0,322 & 0,340 & & \\
\hline GG & 0,036 & 0,046 & & \\
\hline MAF & 0,197 & 0,215 & & \\
\hline rs12452844 & & & $1,01(0,71-1,44)$ & 0,9153 \\
\hline $\mathrm{AA}$ & 0,057 & 0,098 & & \\
\hline $\mathrm{AG}$ & 0,485 & 0,340 & & \\
\hline GG & 0,458 & 0,562 & & \\
\hline MAF & 0,299 & 0,267 & & \\
\hline rs12945905 & & & $0,92(0,60-1,39)$ & 0,7072 \\
\hline $\mathrm{CC}$ & 0,717 & 0,739 & & \\
\hline CT & 0,256 & 0,222 & & \\
\hline $\mathrm{TT}$ & 0,027 & 0,039 & & \\
\hline MAF & 0,155 & 0,150 & & \\
\hline rs12951513 & & & $1,16(0,69-1,92)$ & 0,5644 \\
\hline $\mathrm{CC}$ & 0,831 & 0,809 & & \\
\hline CT & 0,166 & 0,158 & & \\
\hline TT & 0,003 & 0,033 & & \\
\hline MAF & 0,085 & 0,111 & & \\
\hline
\end{tabular}

MAF: frequência do alelo raro; OR: Odds ratio; IC: intervalo de confiança; OR para o alelo raro em um modelo codominante de regressão logística ajustada para idade, IMC, tempo de DM, presença de HAS, triglicérides e uso de estatina. $P \leq 0,005$ foi considerado significante. 
Tabela 9 - Frequência dos genótipos dos polimorfismos no gene AANAT de acordo com o status do declínio da função renal

\begin{tabular}{|c|c|c|c|c|}
\hline & Não Declinante & Declinante & OR (IC 95\%) & Valor de $P$ \\
\hline $\mathbf{N}$ & 312 & 99 & & \\
\hline \multicolumn{5}{|l|}{ AANAT } \\
\hline rs3760138 & & & $0,88(0,57-1,36)$ & 0,5920 \\
\hline GG & 0,265 & 0,333 & & \\
\hline GT & 0,531 & 0,448 & & \\
\hline TT & 0,204 & 0,219 & & \\
\hline MAF & 0,469 & 0,442 & & \\
\hline rs8150 & & & $1,37(0,85-2,11)$ & 0,1960 \\
\hline $\mathrm{CC}$ & 0,090 & 0,143 & & \\
\hline CG & 0,428 & 0,385 & & \\
\hline GG & 0,482 & 0,472 & & \\
\hline MAF & 0,303 & 0,317 & & \\
\hline rs3826287 & & & $1,63(1,05-2,56)$ & 0,0270 \\
\hline $\mathrm{CC}$ & 0,132 & 0,242 & & \\
\hline CG & 0,548 & 0,505 & & \\
\hline GG & 0,320 & 0,253 & & \\
\hline MAF & 0,405 & 0,494 & & \\
\hline rs12946216 & & & $1,02(0,68-1,53)$ & 0,9138 \\
\hline AA & 0,292 & 0,323 & & \\
\hline $\mathrm{AC}$ & 0,509 & 0,456 & & \\
\hline $\mathrm{CC}$ & 0,199 & 0,222 & & \\
\hline MAF & 0,453 & 0,449 & & \\
\hline rs4789300 & & & $1,16(0,77-1,75)$ & 0,4566 \\
\hline $\mathrm{CC}$ & 0,227 & 0,293 & & \\
\hline CT & 0,495 & 0,495 & & \\
\hline TT & 0,278 & 0,212 & & \\
\hline MAF & 0,474 & 0,540 & & \\
\hline rs7210907 & & & $0,94(0,53-1,59)$ & 0,8304 \\
\hline $\mathrm{CC}$ & 0,638 & 0,616 & & \\
\hline CG & 0,330 & 0,354 & & \\
\hline GG & 0,032 & 0,030 & & \\
\hline MAF & 0,197 & 0,207 & & \\
\hline rs12452844 & & & $1,19(0,76-1,85)$ & 0,4326 \\
\hline AA & 0,058 & 0,101 & & \\
\hline $\mathrm{AG}$ & 0,468 & 0,363 & & \\
\hline GG & 0,474 & 0,535 & & \\
\hline MAF & 0,291 & 0,282 & & \\
\hline rs12945905 & & & $1,27(0,74-2,14)$ & 0,3656 \\
\hline $\mathrm{CC}$ & 0,750 & 0,646 & & \\
\hline $\mathrm{CT}$ & 0,221 & 0,323 & & \\
\hline TT & 0,029 & 0,031 & & \\
\hline MAF & 0,139 & 0,191 & & \\
\hline rs12951513 & & & $1,76(0,92-3,24)$ & 0,0811 \\
\hline $\mathrm{CC}$ & 0,849 & 0,724 & & \\
\hline $\mathrm{CT}$ & 0,144 & 0,245 & & \\
\hline TT & 0,007 & 0,031 & & \\
\hline MAF & 0,078 & 0,153 & & \\
\hline
\end{tabular}

MAF: frequência do alelo raro; OR: Odds ratio; IC: intervalo de confiança; OR para o alelo raro em um modelo codominante de regressão logística ajustada para presença de HAS, triglicérides e LDL na fase basal. $P \leq 0,005$ foi considerado significante. 


\section{Gene MTNR1A}

Tabela 10 - Frequência dos genótipos dos polimorfismos no gene MTNR1A de acordo com a ausência ou presença de retinopatia diabética (RD)

\begin{tabular}{|c|c|c|c|c|}
\hline & Ausência de RD & Presença de RD & OR (IC 95\%) & Valor de $P$ \\
\hline $\mathbf{N}$ & 129 & 266 & & \\
\hline \multicolumn{5}{|l|}{ MT1 } \\
\hline rs2165666 & & & $1,01(0,52-1,96)$ & 0,9739 \\
\hline TT & 0,418 & 0,428 & & \\
\hline $\mathrm{TC}$ & 0,411 & 0,421 & & \\
\hline $\mathrm{CC}$ & 0,171 & 0,150 & & \\
\hline MAF & 0,375 & 0,360 & & \\
\hline rs4862705 & & & $0,92(0,64-1,34)$ & 0,6847 \\
\hline AA & 0,132 & 0,071 & & \\
\hline AG & 0,326 & 0,376 & & \\
\hline GG & 0,542 & 0,553 & & \\
\hline MAF & 0,294 & 0,259 & & \\
\hline rs6847693 & & & $1,03(0,66-1,61)$ & 0,8812 \\
\hline TT & 0,023 & 0,038 & & \\
\hline $\mathrm{TC}$ & 0,302 & 0,293 & & \\
\hline $\mathrm{CC}$ & 0,675 & 0,669 & & \\
\hline MAF & 0,174 & 0,184 & & \\
\hline rs11728777 & & & $1,09(0,77-1,55)$ & 0,5975 \\
\hline AA & 0,279 & 0,225 & & \\
\hline AG & 0,496 & 0,549 & & \\
\hline GG & 0,225 & 0,226 & & \\
\hline MAF & 0,527 & 0,500 & & \\
\hline rs6553010 & & & $0,99(0,44-2,26)$ & 0,9924 \\
\hline AA & 0,016 & 0,015 & & \\
\hline AG & 0,197 & 0,202 & & \\
\hline GG & 0,787 & 0,783 & & \\
\hline MAF & 0,112 & 0,114 & & \\
\hline rs1946977 & & & $0,54(0,23-1,25)$ & 0,1526 \\
\hline GG & 0,699 & 0,033 & & \\
\hline GT & 0,341 & 0,300 & & \\
\hline TT & 0,589 & 0,665 & & \\
\hline MAF & 0,240 & 0,184 & & \\
\hline rs7687823 & & & $0,92(0,65-1,30)$ & 0,6466 \\
\hline GG & 0,178 & 0,204 & & \\
\hline GA & 0,574 & 0,486 & & \\
\hline AA & 0,248 & 0,309 & & \\
\hline MAF & 0,465 & 0,445 & & \\
\hline rs13140012 & & & $0,88(0,61-1,27)$ & 0,5220 \\
\hline AA & 0,139 & 0,154 & & \\
\hline AT & 0,566 & 0,508 & & \\
\hline TT & 0,295 & 0,338 & & \\
\hline MAF & 0,422 & 0,407 & & \\
\hline
\end{tabular}

MAF: frequência do alelo raro; OR: Odds ratio; IC: intervalo de confiança; OR para o alelo raro em um modelo codominante de regressão logística ajustada para idade, tempo de DM, presença de HAS, TFGe, uso de inibidores da enzima conversora da angiotensina, uso de bloqueadores do receptor de angiotensina e uso de estatina. $P \leq 0,006$ foi considerado significante. 
Tabela 11 - Frequência dos genótipos dos polimorfismos no gene MTNRlA de acordo com a ausência ou presença de neuropatia periférica (NP)

\begin{tabular}{|c|c|c|c|c|}
\hline & Ausência de NP & Presença de NP & OR (IC 95\%) & Valor de $P$ \\
\hline $\mathbf{N}$ & 181 & 101 & & \\
\hline \multicolumn{5}{|l|}{ MT1 } \\
\hline rs2165666 & & & $0,97(0,65-1,45)$ & 0,9126 \\
\hline $\mathrm{TT}$ & 0,420 & 0,406 & & \\
\hline $\mathrm{TC}$ & 0,414 & 0,436 & & \\
\hline $\mathrm{CC}$ & 0,166 & 0,158 & & \\
\hline MAF & 0,372 & 0,376 & & \\
\hline rs4862705 & & & $0,81(0,51-1,25)$ & 0,3505 \\
\hline AA & 0,110 & 0,060 & & \\
\hline AG & 0,332 & 0,366 & & \\
\hline GG & 0,558 & 0,574 & & \\
\hline MAF & 0,276 & 0,242 & & \\
\hline rs6847693 & & & $1,24(0,73-2,08)$ & 0,4178 \\
\hline TT & 0,027 & 0,029 & & \\
\hline $\mathrm{TC}$ & 0,282 & 0,336 & & \\
\hline $\mathrm{CC}$ & 0,691 & 0,635 & & \\
\hline MAF & 0,168 & 0,198 & & \\
\hline rs11728777 & & & $0,60(0,38-0,94)$ & 0,0266 \\
\hline AA & 0,238 & 0,247 & & \\
\hline AG & 0,497 & 0,634 & & \\
\hline GG & 0,265 & 0,119 & & \\
\hline MAF & 0,513 & 0,435 & & \\
\hline rs6553010 & & & $0,88(0,53-1,44)$ & 0,6287 \\
\hline AA & 0,062 & 0,030 & & \\
\hline AG & 0,335 & 0,356 & & \\
\hline GG & 0,603 & 0,614 & & \\
\hline MAF & 0,229 & 0,207 & & \\
\hline rs1946977 & & & $1,31(0,81-2,12)$ & 0,2570 \\
\hline GG & 0,061 & 0,059 & & \\
\hline GT & 0,282 & 0,326 & & \\
\hline TT & 0,657 & 0,614 & & \\
\hline MAF & 0,201 & 0,222 & & \\
\hline rs7687823 & & & $1,29(0,85-1,97)$ & 0,2200 \\
\hline GG & 0,204 & 0,168 & & \\
\hline GA & 0,453 & 0,634 & & \\
\hline AA & 0,343 & 0,198 & & \\
\hline MAF & 0,430 & 0,386 & & \\
\hline rs13140012 & & & $1,55(1,01-2,39)$ & 0,0436 \\
\hline AA & 0,138 & 0,188 & & \\
\hline AT & 0,497 & 0,584 & & \\
\hline TT & 0,365 & 0,228 & & \\
\hline MAF & 0,386 & 0,480 & & \\
\hline
\end{tabular}

MAF: frequência do alelo raro; OR: Odds ratio; IC: intervalo de confiança; OR para o alelo raro em um modelo codominante de regressão logística ajustada para idade, tempo de DM, presença de HAS, triglicérides, TFGe, uso de inibidores da enzima conversora da angiotensina e uso de estatina. $P \leq 0,006$ foi considerado significante. 
Tabela 12 - Frequência dos genótipos dos polimorfismos no gene MTNRlA de acordo com a ausência ou presença de neuropatia periférica (NP)

\begin{tabular}{|c|c|c|c|c|}
\hline & Ausência de NP & Presença de NP & OR (IC 95\%) & Valor de $P$ \\
\hline $\mathbf{N}$ & 181 & 101 & & \\
\hline \multicolumn{5}{|l|}{ MT1 } \\
\hline rs2165666 & & & $1,03(0,69-1,53)$ & 0,6122 \\
\hline TT & 0,420 & 0,406 & & \\
\hline TC & 0,414 & 0,436 & & \\
\hline $\mathrm{CC}$ & 0,166 & 0,158 & & \\
\hline MAF & 0,372 & 0,376 & & \\
\hline rs4862705 & & & $1,23(0,79-1,93)$ & 0,3535 \\
\hline AA & 0,110 & 0,060 & & \\
\hline AG & 0,332 & 0,366 & & \\
\hline GG & 0,558 & 0,574 & & \\
\hline MAF & 0,276 & 0,242 & & \\
\hline rs6847693 & & & $0,80(0,47-1,35)$ & 0,4075 \\
\hline TT & 0,027 & 0,029 & & \\
\hline $\mathrm{TC}$ & 0,282 & 0,336 & & \\
\hline $\mathrm{CC}$ & 0,691 & 0,635 & & \\
\hline MAF & 0,168 & 0,198 & & \\
\hline rs11728777 & & & $1,63(1,05-2,57)$ & 0,0289 \\
\hline AA & 0,238 & 0,247 & & \\
\hline $\mathrm{AG}$ & 0,497 & 0,634 & & \\
\hline GG & 0,265 & 0,119 & & \\
\hline MAF & 0,513 & 0,435 & & \\
\hline rs6553010 & & & $1,12(0,68-1,85)$ & 0,6522 \\
\hline AA & 0,062 & 0,030 & & \\
\hline $\mathrm{AG}$ & 0,335 & 0,356 & & \\
\hline GG & 0,603 & 0,614 & & \\
\hline MAF & 0,229 & 0,207 & & \\
\hline rs1946977 & & & $0,75(0,47-1,22)$ & 0,2597 \\
\hline GG & 0,061 & 0,059 & & \\
\hline GT & 0,282 & 0,326 & & \\
\hline TT & 0,657 & 0,614 & & \\
\hline MAF & 0,201 & 0,222 & & \\
\hline rs7687823 & & & $0,77(0,50-1,16)$ & 0,2190 \\
\hline GG & 0,204 & 0,168 & & \\
\hline GA & 0,453 & 0,634 & & \\
\hline AA & 0,343 & 0,198 & & \\
\hline MAF & 0,430 & 0,386 & & \\
\hline rs13140012 & & & $0,64(0,41-0,99)$ & 0,0458 \\
\hline AA & 0,138 & 0,188 & & \\
\hline AT & 0,497 & 0,584 & & \\
\hline TT & 0,365 & 0,228 & & \\
\hline MAF & 0,386 & 0,480 & & \\
\hline
\end{tabular}

MAF: frequência do alelo raro; OR: Odds ratio; IC: intervalo de confiança; OR para o alelo raro em um modelo codominante de regressão logística ajustada para doença renal diabética, idade, tempo de DM, presença de HAS, triglicérides, TFGe, uso de inibidores da enzima conversora da angiotensina e uso de estatina. $P \leq 0,006$ foi considerado significante. 
Tabela 13 - Frequência dos genótipos dos polimorfismos no gene MTNRlA de acordo com a ausência ou presença de neuropatia autonômica cardiovascular (NAC)

\begin{tabular}{|c|c|c|c|c|}
\hline & Ausência de NAC & Presença de NAC & OR (IC 95\%) & Valor de $P$ \\
\hline $\mathbf{N}$ & 206 & 85 & & \\
\hline \multicolumn{5}{|l|}{ MT1 } \\
\hline rs2165666 & & & $0,91(0,61-1,35)$ & 0,6642 \\
\hline TT & 0,403 & 0,447 & & \\
\hline TC & 0,427 & 0,388 & & \\
\hline $\mathrm{CC}$ & 0,170 & 0,165 & & \\
\hline \multicolumn{5}{|l|}{ MAF } \\
\hline rs4862705 & & & $1,12(0,72-1,73)$ & 0,6017 \\
\hline AA & 0,082 & 0,082 & & \\
\hline $\mathrm{AG}$ & 0,340 & 0,377 & & \\
\hline GG & 0,578 & 0,541 & & \\
\hline MAF & 0,252 & 0,270 & & \\
\hline rs6847693 & & & $0,67(0,38-1,14)$ & 0,1524 \\
\hline TT & 0,039 & 0,026 & & \\
\hline TC & 0,315 & 0,270 & & \\
\hline $\mathrm{CC}$ & 0,646 & 0,706 & & \\
\hline MAF & 0,196 & 0,158 & & \\
\hline rs11728777 & & & $0,93(0,61-1,43)$ & 0,7731 \\
\hline AA & 0,257 & 0,259 & & \\
\hline $\mathrm{AG}$ & 0,539 & 0,529 & & \\
\hline GG & 0,204 & 0,219 & & \\
\hline MAF & 0,473 & 0,476 & & \\
\hline rs6553010 & & & $0,76(0,46-1,22)$ & 0,2659 \\
\hline AA & 0,063 & 0,048 & & \\
\hline $\mathrm{AG}$ & 0,350 & 0,298 & & \\
\hline GG & 0,587 & 0,654 & & \\
\hline MAF & 0,237 & 0,196 & & \\
\hline rs1946977 & & & $1,07(0,65-1,73)$ & 0,7763 \\
\hline GG & 0,048 & 0,047 & & \\
\hline GT & 0,316 & 0,329 & & \\
\hline TT & 0,636 & 0,624 & & \\
\hline MAF & 0,206 & 0,211 & & \\
\hline rs7687823 & & & $1,06(0,71-1,60)$ & 0,7461 \\
\hline GG & 0,209 & 0,211 & & \\
\hline GA & 0,500 & 0,530 & & \\
\hline AA & 0,291 & 0,259 & & \\
\hline MAF & 0,458 & 0,477 & & \\
\hline rs13140012 & & & $0,91(0,60-1,39)$ & 0,6948 \\
\hline AA & 0,150 & 0,200 & & \\
\hline AT & 0,558 & 0,482 & & \\
\hline TT & 0,292 & 0,318 & & \\
\hline MAF & 0,429 & 0,441 & & \\
\hline
\end{tabular}

MAF: frequência do alelo raro; OR: Odds ratio; IC: intervalo de confiança; OR para o alelo raro em um modelo codominante de regressão logística ajustada para presença de HAS, TFGe, triglicérides e HbA1c. $P \leq 0,006$ foi considerado significante. 
Tabela 14 - Frequência dos genótipos dos polimorfismos no gene MTNRlA de acordo com a ausência ou presença de doença renal diabética (DRD)

\begin{tabular}{|c|c|c|c|c|}
\hline & Ausência de DRD & Presença de DRD & OR (IC 95\%) & Valor de $P$ \\
\hline $\mathbf{N}$ & 332 & 153 & & \\
\hline \multicolumn{5}{|l|}{ MT1 } \\
\hline rs2165666 & & & $0,84(0,61-1,14)$ & 0,2762 \\
\hline TT & 0,471 & 0,437 & & \\
\hline $\mathrm{TC}$ & 0,418 & 0,409 & & \\
\hline $\mathrm{CC}$ & 0,111 & 0,153 & & \\
\hline MAF & 0,358 & 0,320 & & \\
\hline rs4862705 & & & $1,14(0,81-1,60)$ & 0,4319 \\
\hline AA & 0,078 & 0,085 & & \\
\hline AG & 0,374 & 0,386 & & \\
\hline GG & 0,548 & 0,529 & & \\
\hline MAF & 0,265 & 0,277 & & \\
\hline rs6847693 & & & $0,68(0,44-1,04)$ & 0,0814 \\
\hline TT & 0,033 & 0,013 & & \\
\hline $\mathrm{TC}$ & 0,280 & 0,255 & & \\
\hline $\mathrm{CC}$ & 0,687 & 0,732 & & \\
\hline MAF & 0,173 & 0,140 & & \\
\hline rs11728777 & & & $1,02(0,74-1,40)$ & 0,8872 \\
\hline AA & 0,253 & 0,202 & & \\
\hline AG & 0,515 & 0,556 & & \\
\hline GG & 0,232 & 0,242 & & \\
\hline MAF & 0,489 & 0,519 & & \\
\hline rs6553010 & & & $0,38(0,16-0,83)$ & 0,0160 \\
\hline AA & 0,049 & 0,034 & & \\
\hline $\mathrm{AG}$ & 0,330 & 0,282 & & \\
\hline GG & 0,621 & 0,684 & & \\
\hline MAF & 0,213 & 0,174 & & \\
\hline rs1946977 & & & $1,10(0,74-1,61)$ & 0,6208 \\
\hline GG & 0,033 & 0,042 & & \\
\hline GT & 0,346 & 0,307 & & \\
\hline TT & 0,621 & 0,651 & & \\
\hline MAF & 0,195 & 0,205 & & \\
\hline rs7687823 & & & $0,89(0,65-1,22)$ & 0,4940 \\
\hline GG & 0,196 & 0,164 & & \\
\hline GA & 0,509 & 0,500 & & \\
\hline AA & 0,295 & 0,336 & & \\
\hline MAF & 0,450 & 0,411 & & \\
\hline rs13140012 & & & $1,10(0,80-1,52)$ & 0,5386 \\
\hline AA & 0,148 & 0,163 & & \\
\hline AT & 0,509 & 0,510 & & \\
\hline TT & 0,343 & 0,327 & & \\
\hline MAF & 0,402 & 0,418 & & \\
\hline
\end{tabular}

MAF: frequência do alelo raro; OR: Odds ratio; IC: intervalo de confiança; OR para o alelo raro em um modelo codominante de regressão logística ajustada para idade, IMC, tempo de DM, presença de HAS, triglicérides e uso de estatina. $P \leq 0,006$ foi considerado significante. 


\section{ANEXO 6}

\section{ANÁLISE GENÉTICA E CONCENTRAÇÃO DE aMT6s URINÁRIA}

Tabela 1 - Características demográficas, clínicas e laboratoriais dos indivíduos com diabete melito tipo 1 e dosagem de concentrações de aMT6 urinária de acordo com a presença do alelo A no rs4446909

\begin{tabular}{|c|c|c|c|}
\hline & $\mathbf{A X}$ & GG & Valor de $P$ \\
\hline \multicolumn{4}{|l|}{$\begin{array}{l}\text { Características demográficas, } \\
\text { clínicas e laboratoriais }\end{array}$} \\
\hline $\mathrm{N}$ & 16 & 45 & \\
\hline Idade (anos) & $40,5(35,2-47,7)$ & $37(30,5-51)$ & 0,63 \\
\hline Sexo (\% masculino) & 43,7 & 24,4 & 0,14 \\
\hline IMC (kg/m2) & $28,5(24,3-29,8)$ & $24,8(23-27,8)$ & 0,06 \\
\hline Hipertensão arterial (\%) & 37,5 & 55,5 & 0,21 \\
\hline Dislipidemia (\%) & 56,2 & 53,3 & 0,84 \\
\hline TFGe $\left(\mathrm{ml} \cdot \mathrm{min}^{-1} .1 .73 \mathrm{~m}^{2}\right)$ & $80,7(73,3-109,9)$ & $98,5(71,3-110,9)$ & 0,71 \\
\hline Eppworth & $7,5(5-10,7)$ & $8(6-14)$ & 0,24 \\
\hline Pittsburgh & $6(6-9,5)$ & $6(4-8)$ & 0,22 \\
\hline \multicolumn{4}{|l|}{ Características do diabetes } \\
\hline Duração do diabetes (anos) & $25(13,7-33)$ & $24(20-35,5)$ & 0,28 \\
\hline Idade ao diagnóstico (anos) & $18(11,7-24,5)$ & $13(7-19,5)$ & 0,06 \\
\hline $\mathrm{HbA}_{1} \mathrm{C}(\%)$ & $8,0(7-9,1)$ & $8,1(7,5-9,3)$ & 0,5 \\
\hline \multicolumn{4}{|l|}{ Frutosamina $(\mu \mathrm{mol} / \mathrm{L})$} \\
\hline Dose de insulina/peso (UI/Kg) & $0,55(0,5-0,76)$ & $0,63(0,47-0,78)$ & 0,58 \\
\hline Doença Renal Diabética (\%) & 12,5 & 20 & 0,48 \\
\hline \multicolumn{4}{|l|}{ Hábitos } \\
\hline Trabalhador Noturno (\%) & 6,2 & 4,4 & 0,71 \\
\hline \multicolumn{4}{|l|}{ Dia da coleta } \\
\hline Tempo total de coleta $(\mathrm{h})$ & $11,7(10,4-12,3)$ & $12(10,8-12,8)$ & 0,63 \\
\hline Volume urinário (ml) & $900(700-1466)$ & $850(545-1165)$ & 0,46 \\
\hline Assistiu televisão (\%) & 93,7 & 91,1 & 0,73 \\
\hline Horas na televisão & $3,5(1,8-5)$ & $4(3-5)$ & 0,26 \\
\hline Usou computador (\%) & 12,5 & 11,1 & 0,88 \\
\hline Horas no computador & $2,2(0,5-4)$ & $2(1,2-6)$ & 0,55 \\
\hline Uso de tablets $(\%)$ & 6,2 & 2,2 & 0,43 \\
\hline Horas no tablet & $2(2)$ & $3(3)$ & 0,31 \\
\hline Uso de celular $(\%)$ & 68,7 & 73,3 & 0,72 \\
\hline Horas no celular & $2,5(2-4)$ & $4(2,2-5)$ & 0,27 \\
\hline Se levantou a noite (\% de sim) & 43,7 & 53,3 & 0,51 \\
\hline Acendeu a luz a noite ( $\%$ de sim) & 37,5 & 46,6 & 0,52 \\
\hline \multicolumn{4}{|l|}{ Uso de medicamentos } \\
\hline IECA $(\%)$ & 31,2 & 40 & 0,53 \\
\hline \multicolumn{4}{|l|}{ BRA $(\%)$} \\
\hline Beta-Bloq (\%) & 6,2 & 13,3 & 0,41 \\
\hline Diuréticos $(\%)$ & 12,5 & 6,6 & 0,48 \\
\hline Estatina $(\%)$ & 50 & 53,3 & 0,81 \\
\hline IRSS (\%) & 18,7 & 28,8 & 0,41 \\
\hline Benzodiazepínicos (\%) & 12,5 & 4,44 & 0,29 \\
\hline
\end{tabular}

Resultados expressos como mediana e intervalo interquartílico. TFGe: Taxa de filtração glomerular estimada; $\mathrm{HbA}_{1} \mathrm{C}$ : Hemoglobina glicada; IECA: Inibidores da enzima conversora da angiotensina; BRA: Bloqueadores do receptor de Angiotensina II; IRSS: Inibidor de recaptação de serotonina; $P \leq 0,05$ foi considerado significante. 
Tabela 2 - Concentrações de aMT6s urinária de acordo com a presença do alelo raro A no rs4862705 do gene MT1

\begin{tabular}{lccc}
\hline & $\begin{array}{c}\text { Portadores do alelo raro } \\
\text { A }\end{array}$ & $\begin{array}{c}\text { Não portadores do } \\
\text { alelo raro A }\end{array}$ & Valor de $\boldsymbol{P}$ \\
\hline $\mathrm{N}$ & 19 & 42 & \\
$\begin{array}{l}\text { aMT6s/Creatinina urinária } \\
(\mathbf{n g} / \mathbf{m g})\end{array}$ & $28,6(16,5-52,9)$ & $20,5(9,5-46,4)$ & 0,02428 \\
\hline
\end{tabular}

$P \leq 0,05$ foi considerado significante 


\section{REFERÊNCIAS}

1. World Health Organization - WHO. Global Report on Diabetes. Geneva: World Health Organization Press; 2016.

2. Brownlee M. Biochemistry and molecular cell biology of diabetic complication. Nature. 2001;414:813-20.

3. Barrett EJ, Liu Z, Khamaisi M, King GL, Klein R, Klein BEK, Hughes TM, Craft S, Freedman BI, Bowden DW, Vinik AI, Casellini CM. Diabetic microvascular disease: an endocrine society scientific statement. J Clin Endocrinol Metab. 2017;102(12):4343-410.

4. Corrêa-Giannella ML, Vieira SM. A predisposição genética para o desenvolvimento da microangiopatia no DM1. Arq Bras Endrocrinol Metab. 2008:52(2):375-86.

5. Shastry BS. SNPs and haplotypes: genetic markers for disease and drug response. Int J Mol Med. 2003;11(3):379-8.

6. Vieira SM, Monteiro MB, Marques T, Luna AM, Fortes MA, Nery M, Queiroz M, Dib SA, Vendramini MF, Azevedo MJ, Canani LH, Parisi MC, Pavin EJ, GiannellaNeto D, Corrêa-Giannella ML. Association of genetic variants in the promoter region of genes encoding p22phox (CYBA) and glutamate cysteine ligase catalytic subunit (GCLC) and renal disease in patients with type 1 diabetes mellitus. BMC Med Genet. 2011;12:129.

7. Marques T, Patente TA, Monteiro MB, Cavaleiro AM, Queiroz MS, Nery M, de Azevedo MJ, Canani LH, Parisi MC, Moura-Neto A, Passarelli M, Giannella-Neto D, Machado UF, Corrêa-Giannella ML. Association of single nucleotide polymorphisms in 
the gene encoding GLUT1 and diabetic nephropathy in Brazilian patients with type 1 diabetes mellitus. Clin Chim Acta. 2015;444:170-5.

8. Mohammedi K, Patente TA, Bellili-Muñoz N, Driss F, Monteiro MB, Roussel R, Pavin EJ, Seta N, Fumeron F, Azevedo MJ, Canani LH, Hadjadj S, Marre M, CorrêaGiannella ML, Velho G. Catalase activity, allelic variations in the catalase gene and risk of kidney complications in patients with type 1 diabetes. Diabetologia. 2013;56(12):2733-42.

9. Patente TA, Mohammedi K, Bellili-Muñoz N, Driss F, Sanchez M, Fumeron F, Roussel R, Hadjadj S, Corrêa-Giannella ML, Marre M, Velho G. Allelic variations in the CYBA gene of NADPH oxidase and risk of kidney complications in patients with type 1 diabetes. Free Radic Biol Med. 2015;86:16-24.

10. Perez RV, Machado CG, Santos-Bezerra DP, Admoni SN, Patente TA, Monteiro MB, Cavaleiro AM, Queiroz MS, Nery M, Corrêa-Giannella ML. Allelic variations in genes belonging to glutathione system increase proliferative retinopathy risk in type 1 diabetes individuals. Gene. 2019;703:120-4.

11. Admoni SN, Santos-Bezerra DP, Perez RV, Patente TA, Monteiro MB, Cavaleiro AM, Parisi MC, Moura Neto A, Pavin EJ, Queiroz MS, Nery M, CorreaGiannella ML. Glutathione peroxidase 4 functional variant rs713041 modulates the risk for cardiovascular autonomic neuropathy in individuals with type 1 diabetes. Diab Vasc Dis Res. 2019;16(3):297-9.

12. Cipolla-Neto J, Amaral FGD. Melatonin as a hormone: new physiological and clinical insights. Endocr Rev. 2018;39(6):990-1028.

13. Cipolla-Neto J, Amaral FG, Afeche SC, Tan DX, Reiter RJ. Melatonin, energy metabolism, and obesity: a review. J Pineal Res. 2014;56(4):371-81.

14. Bonnefont-Rousselot D, Collin F. Melatonin: action as antioxidant and potential applications in human disease and aging. Toxicology. 2010;278(1):55-67. 
15. Sánchez A, Calpena AC, Clares B. Evaluating the oxidative stress in inflammation: role of melatonin. Int J Mol Sci. 2015;16(8):16981-7004.

16. Tan DX, Manchester LC, Esteban-Zubero E, Zhou Z, Reiter RJ. Melatonin as a potent and inducible endogenous antioxidant: synthesis and metabolism. Molecules. 2015;20(10):18886-906.

17. Lerner A, Case J, Takahashi Y, Lee T, Mori W. Isolation of melatonin the pineal gland extract that lightens melanocytes. J Am Chem Soc. 1958;80(10):2587.

18. Acuña-Castroviejo D, Escames G, Venegas C, Díaz-Casado ME, Lima-Cabello E, López LC, Rosales-Corral S, Tan DX, Reiter RJ. Extrapineal melatonin: sources, regulation, and potential functions. Cell Mol Life Sci. 2014;71(16):2997-3025.

19. Klein DC, Ganguly S, Coon S, Weller JL, Obsil T, Hickman A, Dyda F. 14-3-3 Proteins and photoneuroendocrine transduction: role in controlling the daily rhythm in melatonin. Biochem Soc Trans. 2002;30(4):365-73.

20. Kvetnoy IM. Extrapineal melatonin: location and role within diffuse neuroendocrine system. Histochem J. 1999;31(1):1-12.

21. Ostrin LA. Ocular and systemic melatonin and the influence of light exposure. Clin Exp Optom. 2019;102(2):99-108.

22. Klein DC, Schaad NL, Namboordiri MA, Yu L, Weller JL. Regulation of pineal serotonin N-acetyltransferase activity. Biochem Soc Trans. 1992;20(2):299-304.

23. Ganguly S, Coon SL, Klein DC. Control of melatonin synthesis in the mammalian pineal gland: the critical role of serotonin acetylation. Cell Tissue Res. 2002;309(1):127-37.

24. Claustrat B, Leston J. Melatonin: physiological effects in humans. Neurochirurgie. 2015;61(2-3):77-84. 
25. Bubenik GA. Gastrointestinal melatonin: localization, function, and clinical relevance. Dig Dis Sci. 2002;47(10):2336-48.

26. Klein DC, Weller JL. Rapid light-induced decrease in pineal serotonin Nacetyltransferase activity. Science. 1972;177(4048):532-3.

27. Reiter RJ. Melatonin: the chemical expression of darkness. Mol Cell Endocrinol. 1991;79(1-3):C153-8.

28. Lemmer B. Discoveries of rhythms in human biological functions: a historical review. Chronobiol Int. 2009;26(6):1019-68.

29. Mazzoccoli G, Pazienza V, Vinciguerra M. Clock genes and clock-controlled genes in the regulation of metabolic rhythms. Chronobiol Int. 2012;29(3):227-51.

30. Schibler U, Sassone-Corsi P. A web of circadian pacemakers. Cell. 2002;111(7):919-22.

31. Karthikeyan R, Marimuthu G, Spence DW, Pandi-Perumal SR, BaHammam AS, Brown GM, Cardinali DP. Should we listen to our clock to prevent type 2 diabetes mellitus? Diabetes Res Clin Pract. 2014;106(2):182-90.

32. Follett BK. "Seasonal changes in the neuroendocrine system": some reflections. Front Neuroendocrinol. 2015;37:3-12.

33. Reiter RJ, Tan DX, Gitto E, Sainz RM, Mayo JC, Leon J, Manchester LC, Vijayalaxmi, Kilic E, Kilic U. Pharmacological utility of melatonin in reducing oxidative cellular and molecular damage. Pol J Pharmacol. 2004;56(2):159-70.

34. von Gall C, Stehle JH, Weaver DR. Mammalian melatonin receptors: molecular biology and signal transduction. Cell Tissue Res. 2002;309(1):151-62. 
35. Morgan PJ, Barrett P, Howell HE, Helliwell R. Melatonin receptors: localization, molecular pharmacology and physiological significance. Neurochem Int. 1994;24(2):101-46.

36. Vanecek J. Cellular mechanisms of melatonin action. Physiol Rev. 1998;78(3):687-721.

37. Armstrong SM, Redman JR. Melatonin: a chronobiotic with anti-aging properties? Med Hypotheses. 1991;34(4):300-9.

38. Peschke E, Frese T, Chankiewitz E, Peschke D, Preiss U, Schneyer U, Spessert R, Mühlbauer E. Diabetic Goto Kakizaki rats as well as type 2 diabetic patients show a decreased diurnal serum melatonin level and an increased pancreatic melatonin-receptor status. J Pineal Res. 2006;40(2):135-43.

39. Garcia RA, Afeche SC, Scialfa JH, do Amaral FG, dos Santos SH, Lima FB, Young ME, Cipolla-Neto J. Insulin modulates norepinephrine-mediated melatonin synthesis in cultured rat pineal gland. Life Sci. 2008;82(1-2):108-14.

40. Picinato MC, Haber EP, Carpinelli AR, Cipolla-Neto J. Daily rhythm of glucose-induced insulin secretion by isolated islets from intact and pinealectomized rat. J Pineal Res. 2002;33(3):172-7.

41. Nogueira TC, Lellis-Santos C, Jesus DS, Taneda M, Rodrigues SC, Amaral FG, Lopes AM, Cipolla-Neto J, Bordin S, Anhê GF. Absence of melatonin induces nighttime hepatic insulin resistance and increased gluconeogenesis due to stimulation of nocturnal unfolded protein response. Endocrinology. 2011;152(4):1253-63.

42. Peschke E, Mühlbauer E. New evidence for a role of melatonin in glucose regulation. Best Pract Res Clin Endocrinol Metab. 2010;24(5):829-41. 
43. Mulder H, Nagorny CL, Lyssenko V, Groop L. Melatonin receptors in pancreatic islets: good morning to a novel type 2 diabetes gene. Diabetologia. 2009;52(7):1240-9.

44. Bähr I, Mühlbauer E, Schucht H, Peschke E. Melatonin stimulates glucagon secretion in vitro and in vivo. J Pineal Res. 2011;50(3):336-44.

45. Rubio-Sastre P, Scheer FA, Gómez-Abellán P, Madrid JA, Garaulet M. Acute melatonin administration in humans impairs glucose tolerance in both the morning and evening. Sleep. 2014;37(10):1715-9.

46. Lima FB, Machado UF, Bartol I, Seraphim PM, Sumida DH, Moraes SM, et al. Pinealectomy causes glucose intolerance and decreases adipose cell responsiveness to insulin in rats. Am J Physiol. 1998;275(6 Pt 1):E934-41.

47. Mendes C, Lopes AM, do Amaral FG, Peliciari-Garcia RA, Turati AeO, Hirabara SM, Scialfa Falcão JH, Cipolla-Neto J. Adaptations of the aging animal to exercise: role of daily supplementation with melatonin. J Pineal Res. 2013;55(3):22939.

48. Karlsson B, Knutsson A, Lindahl B. Is there an association between shift work and having a metabolic syndrome? Results from a population based study of 27,485 people. Occup Environ Med. 2001;58(11):747-52.

49. Fonken LK, Weil ZM, Nelson RJ. Dark nights reverse metabolic disruption caused by dim light at night. Obesity (Silver Spring). 2013;21(6):1159-64.

50. McMullan CJ, Schernhammer ES, Rimm EB, Hu FB, Forman JP. Melatonin secretion and the incidence of type 2 diabetes. JAMA. 2013;309(13):1388-96.

51. Mäntele S, Otway DT, Middleton B, Bretschneider S, Wright J, Robertson MD, Skene DJ, Johnston JD. Daily rhythms of plasma melatonin, but not plasma leptin or 
leptin mRNA, vary between lean, obese and type 2 diabetic men. PLoS One. 2012;7(5):e37123.

52. Nagorny C, Lyssenko V. Tired of diabetes genetics? Circadian rhythms and diabetes: the MTNR1B story? Curr Diab Rep. 2012;12(6):667-72.

53. Prokopenko I, Langenberg C, Florez JC, Saxena R, Soranzo N, Thorleifsson G, Loos RJ, Manning AK, Jackson AU, Aulchenko Y, Potter SC, Erdos MR, Sanna S, Hottenga JJ, Wheeler E, Kaakinen M, Lyssenko V, Chen WM, Ahmadi K, Beckmann JS, Bergman RN, Bochud M, Bonnycastle LL, Buchanan TA, Cao A, Cervino A, Coin L, Collins FS, Crisponi L, de Geus EJ, Dehghan A, Deloukas P, Doney AS, Elliott P, Freimer N, Gateva V, Herder C, Hofman A, Hughes TE, Hunt S, Illig T, Inouye M, Isomaa B, Johnson T, Kong A, Krestyaninova M, Kuusisto J, Laakso M, Lim N, Lindblad U, Lindgren CM, McCann OT, Mohlke KL, Morris AD, Naitza S, Orrù M, Palmer CN, Pouta A, Randall J, Rathmann W, Saramies J, Scheet P, Scott LJ, Scuteri A, Sharp S, Sijbrands E, Smit JH, Song K, Steinthorsdottir V, Stringham HM, Tuomi T, Tuomilehto J, Uitterlinden AG, Voight BF, Waterworth D, Wichmann HE, Willemsen G, Witteman JC, Yuan X, Zhao JH, Zeggini E, Schlessinger D, Sandhu M, Boomsma DI, Uda M, Spector TD, Penninx BW, Altshuler D, Vollenweider P, Jarvelin MR, Lakatta E, Waeber G, Fox CS, Peltonen L, Groop LC, Mooser V, Cupples LA, Thorsteinsdottir U, Boehnke M, Barroso I, Van Duijn C, Dupuis J, Watanabe RM, Stefansson K, McCarthy MI, Wareham NJ, Meigs JB, Abecasis GR. Variants in MTNR1B influence fasting glucose levels. Nat Genet. 2009;41(1):77-81.

54. Bouatia-Naji N, Bonnefond A, Cavalcanti-Proença C, Sparsø T, Holmkvist J, Marchand M, Delplanque J, Lobbens S, Rocheleau G, Durand E, De Graeve F, Chèvre JC, Borch-Johnsen K, Hartikainen AL, Ruokonen A, Tichet J, Marre M, Weill J, Heude B, Tauber M, Lemaire K, Schuit F, Elliott P, Jørgensen T, Charpentier G, Hadjadj S, Cauchi S, Vaxillaire M, Sladek R, Visvikis-Siest S, Balkau B, Lévy-Marchal C, Pattou F, Meyre D, Blakemore AI, Jarvelin MR, Walley AJ, Hansen T, Dina C, Pedersen O, Froguel P. A variant near MTNR1B is associated with increased fasting plasma glucose levels and type 2 diabetes risk. Nat Genet. 2009;41(1):89-94. 
55. Costes S, Boss M, Thomas AP, Matveyenko AV. Activation of melatonin signaling promotes $\beta$-cell survival and function. Mol Endocrinol. 2015;29(5):682-92.

56. Gomes PRL, Vilas-Boas EA, Leite EA, Munhoz AC, Lucena CF, Amaral FGD, Carpinelli AR, Cipolla-Neto J. Melatonin regulates maternal pancreatic remodeling and B-cell function during pregnancy and lactation. J Pineal Res. 2021 Jan 18:e12717.

57. Ma X, Idle JR, Krausz KW, Gonzalez FJ. Metabolism of melatonin by human cytochromes p450. Drug Metab Dispos. 2005;33(4):489-94.

58. Young IM, Leone RM, Francis P, Stovell P, Silman RE. Melatonin is metabolized to $\mathrm{N}$-acetyl serotonin and 6-hydroxymelatonin in man. J Clin Endocrinol Metab. 1985;60(1):114-9.

59. Graham C, Cook MR, Kavet R, Sastre A, Smith DK. Prediction of nocturnal plasma melatonin from morning urinary measures. J Pineal Res. 1998;24(4):230-8.

60. Pääkkönen T, Mäkinen TM, Leppäluoto J, Vakkuri O, Rintamäki H, Palinkas LA, Hassi J. Urinary melatonin: a noninvasive method to follow human pineal function as studied in three experimental conditions. J Pineal Res. 2006;40(2):110-5.

61. Piconi L, Quagliaro L, Ceriello A.. Oxidative stress in diabetes. Clin Chem Lab Med. 2003;41(9):1144-9.

62. Reiter RJ, Rosales-Corral S, Tan DX, Jou MJ, Galano A, Xu B. Melatonin as a mitochondria-targeted antioxidant: one of evolution's best ideas. Cell Mol Life Sci. 2017;74(21):3863-81.

63. Ukkola O, Erkkilä PH, Savolainen MJ, Kesäniemi YA. Lack of association between polymorphisms of catalase, copper-zinc superoxide dismutase (SOD), extracellular SOD and endothelial nitric oxide synthase genes and macroangiopathy in patients with type 2 diabetes mellitus. J Intern Med. 2001;249(5):451-9. 
64. Meister A. Glutathione, ascorbate, and cellular protection. Cancer Res. 1994;54:1969-75.

65. Varvarovska J, Racek J, Stozicky F, Soucek J, Trefil L, Pomahacova R. Parameters of oxidative stress in children with type 1 diabetes mellitus and their relatives. J Diabetes Complications. 2003;17(1):7-10.

66. Ceriello A, Bortolotti N, Motz E, Crescentini A, Lizzio S, Russo A, Tonuti L, Taboga C. Meal-generated oxidative stress in type 2 diabetic patients. . Diabetes Care. 1998;21(9):1529-33.

67. Corrêa-Giannella ML, Vieira SM. [Genetic susceptibility to microangiopathy development in Type 1 diabetes mellitus]. Arq Bras Endocrinol Metabol. 2008;52(2):375-86.

68. Manchester LC, Coto-Montes A, Boga JA, Andersen LP, Zhou Z, Galano A, Vriend J, Tan DX, Reiter RJ. Melatonin: an ancient molecule that makes oxygen metabolically tolerable. J Pineal Res. 2015;59(4):403-19.

69. Galano A, Tan DX, Reiter RJ. On the free radical scavenging activities of melatonin's metabolites, AFMK and AMK. J Pineal Res. 2013;54(3):245-57.

70. Fischer TW, Kleszczyński K, Hardkop LH, Kruse N, Zillikens D. Melatonin enhances antioxidative enzyme gene expression (CAT, GPx, SOD), prevents their UVR-induced depletion, and protects against the formation of DNA damage (8-hydroxy-2'-deoxyguanosine) in ex vivo human skin. J Pineal Res. 2013;54(3):30312 .

71. Reiter RJ, Tan DX, Sainz RM, Mayo JC, Lopez-Burillo S. Melatonin: reducing the toxicity and increasing the efficacy of drugs. J Pharm Pharmacol. 2002;54(10):1299321. 
72. Galano A, Medina ME, Tan DX, Reiter RJ. Melatonin and its metabolites as copper chelating agents and their role in inhibiting oxidative stress: a physicochemical analysis. J Pineal Res. 2015;58(1):107-16.

73. Reiter RJ, Mayo JC, Tan DX, Sainz RM, Alatorre-Jimenez M, Qin L. Melatonin as an antioxidant: under promises but over delivers. J Pineal Res. 2016;61(3):253-78.

74. Kücükakin B, Gögenur I, Reiter RJ, Rosenberg J. Oxidative stress in relation to surgery: is there a role for the antioxidant melatonin? J Surg Res. 2009;152(2):338-47.

75. Gitto E, Karbownik M, Reiter RJ, Tan DX, Cuzzocrea S, Chiurazzi P, Cordaro S, Corona G, Trimarchi G, Barberi I. Effects of melatonin treatment in septic newborns. Pediatr Res. 2001;50(6):756-60.

76. Gitto E, Reiter RJ, Cordaro SP, La Rosa M, Chiurazzi P, Trimarchi G, Gitto P, Calabrò MP, Barberi I. Oxidative and inflammatory parameters in respiratory distress syndrome of preterm newborns: beneficial effects of melatonin. Am J Perinatol. 2004;21(4):209-16.

77. Brusco LI, Márquez M, Cardinali DP. Monozygotic twins with Alzheimer's disease treated with melatonin: Case report. J Pineal Res. 1998;25(4):260-3.

78. Wang X. The antiapoptotic activity of melatonin in neurodegenerative diseases. CNS Neurosci Ther. 2009;15(4):345-57.

79. Dominguez-Rodriguez A, Abreu-Gonzalez P, Reiter RJ. Clinical aspects of melatonin in the acute coronary syndrome. Curr Vasc Pharmacol. 2009;7(3):367-73.

80. Escames G, Acuña-Castroviejo D, López LC, Tan DX, Maldonado MD, Sánchez-Hidalgo M, León J, Reiter RJ. Pharmacological utility of melatonin in the treatment of septic shock: experimental and clinical evidence. J Pharm Pharmacol. 2006;58(9):1153-65. 
81. López-González A, Álvarez-Sánchez N, Lardone PJ, Cruz-Chamorro I, Martínez-López A, Guerrero JM, Reiter RJ, Carrillo-Vico A. Melatonin treatment improves primary progressive multiple sclerosis: a case report. J Pineal Res. 2015;58(2):173-7.

82. Liot G, Valette J, Pépin J, Flament J, Brouillet E. Energy defects in Huntington's disease: Why "in vivo" evidence matters. Biochem Biophys Res Commun. 2017;483(4):1084-95.

83. Ha H, Yu MR, Kim KH. Melatonin and taurine reduce early glomerulopathy in diabetic rats. Free Radic Biol Med. 1999;26(7-8):944-50.

84. Gürpınar T, Ekerbiçer N, Uysal N, Barut T, Tarakçı F, Tuglu MI. The effects of the melatonin treatment on the oxidative stress and apoptosis in diabetic eye and brain. ScientificWorldJournal. 2012;2012:498489.

85. Sudnikovich EJ, Maksimchik YZ, Zabrodskaya SV, Kubyshin VL, Lapshina EA, Bryszewska M, Reiter RJ, Zavodnik IB. Melatonin attenuates metabolic disorders due to streptozotocin-induced diabetes in rats. Eur J Pharmacol. 2007;569(3):180-7.

86. Ji ZZ, Xu YC. Melatonin protects podocytes from angiotensin II-induced injury in an in vitro diabetic nephropathy model. Mol Med Rep. 2016;14(1):920-6.

87. Liu F, Zhang S, Xu R, Gao S, Yin J. Melatonin attenuates endothelial-tomesenchymal transition of glomerular endothelial cells via regulating miR-497/ROCK in diabetic nephropathy. Kidney Blood Press Res. 2018;43(5):1425-36.

88. Elbe H, Vardi N, Esrefoglu M, Ates B, Yologlu S, Taskapan C. Amelioration of streptozotocin-induced diabetic nephropathy by melatonin, quercetin, and resveratrol in rats. Hum Exp Toxicol. 2015;34(1):100-13. 
89. Zhang M, Lin J, Wang S, Cheng Z, Hu J, Wang T, Man W, Yin T, Guo W, Gao E, Reiter RJ, Wang H, Sun D. Melatonin protects against diabetic cardiomyopathy through Mst1/Sirt3 signaling. J Pineal Res. 2017;63(2).

90. Amaral FG, Turati AO, Barone M, Scialfa JH, do Carmo Buonfiglio D, Peres R, Peliciari-Garcia RA, Afeche SC, Lima L, Scavone C, Bordin S, Reiter RJ, MennaBarreto L, Cipolla-Neto J. Melatonin synthesis impairment as a new deleterious outcome of diabetes-derived hyperglycemia. J Pineal Res. 2014;57(1):67-79.

91. Bach AG, Mühlbauer E, Peschke E. Adrenoceptor expression and diurnal rhythms of melatonin and its precursors in the pineal gland of type 2 diabetic gotokakizaki rats. Endocrinology. 2010;151(6):2483-93.

92. Kor Y, Geyikli I, Keskin M, Akan M. Preliminary study: Evaluation of melatonin secretion in children and adolescents with type 1 diabetes mellitus. Indian $\mathbf{J}$ Endocrinol Metab. 2014;18(4):565-8.

93. Chen W, Cao H, Lu QY, Wang N, Zhao SZ, Xu X, Zheng Z. Urinary 6sulfatoxymelatonin level in diabetic retinopathy patients with type 2 diabetes. Int $\mathrm{J}$ Clin Exp Pathol. 2014;7(7):4317-22.

94. Hikichi T, Tateda N, Miura T. Alteration of melatonin secretion in patients with type 2 diabetes and proliferative diabetic retinopathy. Clin Ophthalmol. 2011;5:655-60.

95. Kalere I, Konrāde I, Proskurina A, Upmale S, Zaķe T, Limba N, Krievina G, Lejnieks A, Tretjakovs P. editors. Melatonin concentrations and sleep quality in patients with type 2 diabetes and obesity. Proceedings of the Latvian Academy of Sciences Section B Natural, Exact, and Applied Sciences. 2019;73(2):152-157.

96. Tutuncu NB, Batur MK, Yildirir A, Tutuncu T, Deger A, Koray Z, Erbas B, Kabakci G, Aksoyek S, Erbas T. Melatonin levels decrease in type 2 diabetic patients with cardiac autonomic neuropathy. J Pineal Res. 2005;39(1):43-9. 
97. Coon SL, Mazuruk K, Bernard M, Roseboom PH, Klein DC, Rodriguez IR. The human serotonin $\mathrm{N}$-acetyltransferase (EC 2.3.1.87) gene (AANAT): structure, chromosomal localization, and tissue expression. Genomics. 1996;34(1):76-84.

98. Zienolddiny S, Haugen A, Lie JA, Kjuus H, Anmarkrud KH, Kjærheim K. Analysis of polymorphisms in the circadian-related genes and breast cancer risk in Norwegian nurses working night shifts. Breast Cancer Res. 2013;15(4):R53.

99. Soria V, Martínez-Amorós E, Escaramís G, Valero J, Crespo JM, GutiérrezZotes A, Bayés M, Martorell L, Vilella E, Estivill X, Menchón JM, Gratacòs M, Urretavizcaya M. Resequencing and association analysis of arylalkylamine Nacetyltransferase (AANAT) gene and its contribution to major depression susceptibility. J Pineal Res. 2010;49(1):35-44.

100. Rabstein S, Harth V, Justenhoven C, Pesch B, Plöttner S, Heinze E, Lotz A, Baisch C, Schiffermann M, Brauch H, Hamann U, Ko Y, Brüning T; GENICA Consortium. Polymorphisms in circadian genes, night work and breast cancer: results from the GENICA study. Chronobiol Int. 2014;31(10):1115-22.

101. Geoffroy PA, Boudebesse C, Henrion A, Jamain S, Henry C, Leboyer M, Bellivier F, Etain B. An ASMT variant associated with bipolar disorder influences sleep and circadian rhythms: a pilot study. Genes Brain Behav. 2014;13(3):299-304.

102. Jonsson L, Ljunggren E, Bremer A, Pedersen C, Landén M, Thuresson K, Giacobini M, Melke J. Mutation screening of melatonin-related genes in patients with autism spectrum disorders. BMC Med Genomics. 2010;3:10.

103. Gałecki P, Szemraj J, Bartosz G, Bieńkiewicz M, Gałecka E, Florkowski A, Lewiński A, Karbownik-Lewińska M. Single-nucleotide polymorphisms and mRNA expression for melatonin synthesis rate-limiting enzyme in recurrent depressive disorder. J Pineal Res. 2010;48(4):311-7. 
104. Warrier V, Chee V, Smith P, Chakrabarti B, Baron-Cohen S. A comprehensive meta-analysis of common genetic variants in autism spectrum conditions. Mol Autism. 2015;6:49.

105. Kripke DF, Nievergelt CM, Tranah GJ, Murray SS, McCarthy MJ, Rex KM, Parimi N, Kelsoe JR. Polymorphisms in melatonin synthesis pathways: possible influences on depression. J Circadian Rhythms. 2011;9:8.

106. Xia Q, Chen ZX, Wang YC, Ma YS, Zhang F, Che W, Fu D, Wang XF. Association between the melatonin receptor 1B gene polymorphism on the risk of type 2 diabetes, impaired glucose regulation: a meta-analysis. PLoS One. 2012;7(11):e50107.

107. Tam CH, Ho JS, Wang Y, Lee HM, Lam VK, Germer S, Martin M, So WY, Ma RC, Chan JC, Ng MC. Common polymorphisms in MTNR1B, G6PC2 and GCK are associated with increased fasting plasma glucose and impaired beta-cell function in Chinese subjects. PLoS One. 2010;5(7):e11428.

108. Zhang C, Bao W, Rong Y, Yang H, Bowers K, Yeung E, Kiely M. Genetic variants and the risk of gestational diabetes mellitus: a systematic review. Hum Reprod Update. 2013;19(4):376-90.

109. Bonnefond A, Clément N, Fawcett K, Yengo L, Vaillant E, Guillaume JL, Dechaume A, Payne F, Roussel R, Czernichow S, Hercberg S, Hadjadj S, Balkau B, Marre M, Lantieri O, Langenberg C, Bouatia-Naji N; Meta-Analysis of Glucose and Insulin-Related Traits Consortium (MAGIC), Charpentier G, Vaxillaire M, Rocheleau G, Wareham NJ, Sladek R, McCarthy MI, Dina C, Barroso I, Jockers R, Froguel P. Rare MTNR1B variants impairing melatonin receptor 1B function contribute to type 2 diabetes. Nat Genet. 2012;44(3):297-301.

110. Natarajan R, Einarsdottir E, Riutta A, Hagman S, Raunio M, Mononen N, Lehtimäki T, Elovaara I. Melatonin pathway genes are associated with progressive 
subtypes and disability status in multiple sclerosis among Finnish patients. $\mathbf{J}$ Neuroimmunol. 2012;250(1-2):106-10.

111. Lin JD, Yang SF, Wang YH, Fang WF, Lin YC, Liou BC, Lin YF, Tang KT, Cheng CW. Associations of melatonin receptor gene polymorphisms with Graves' disease. PLoS One. 2017;12(9):e0185529.

112. Li C, Shi Y, You L, Wang L, Chen ZJ. Melatonin receptor 1A gene polymorphism associated with polycystic ovary syndrome. Gynecol Obstet Invest. 2011;72(2):130-4

113. Samimi-Fard S, Abreu-Gonzalez P, Dominguez-Rodriguez A, Jimenez-Sosa A. A case-control study of melatonin receptor type 1A polymorphism and acute myocardial infarction in a Spanish population. J Pineal Res. 2011;51(4):400-4.

114. Li C, Qiao B, Zhan Y, Peng W, Chen ZJ, Sun L, Zhang J, Zhao L, Gao Q. Association between genetic variations in MTNR1A and MTNR1B genes and gestational diabetes mellitus in Han Chinese women. Gynecol Obstet Invest. 2013;76(4):221-7.

115. Tarnowski M, Malinowski D, Safranow K, Dziedziejko V, Pawlik A. MTNR1A and MTNR1B gene polymorphisms in women with gestational diabetes. Gynecol Endocrinol. 2017;33(5):395-8.

116. De Ferranti SD, De Boer IH, Fonseca V, Fox CS, Golden SH, Lavie CJ, Magge SN, Marx N, McGuire DK, Orchard TJ, Zinman B, Eckel RH. Type 1 diabetes mellitus and cardiovascular disease: a scientific statement from the American Heart Association and American Diabetes Association. Circulation. 2014;130(13):1110-30.

117. Suguna S, Nandal D, Kamble S, Bharatha A, Kunkulol R. Genomic DNA isolation from human whole blood samples by non enzymatic salting out method. Int $\mathbf{J}$ Pharm Pharm Sci. 2014;6(6):198-9. 
118. Bertolazi AN, Fagondes SC, Hoff LS, Pedro VD, Menna Barreto SS, Johns MW. Portuguese-language version of the Epworth sleepiness scale: validation for use in Brazil. J Bras Pneumol. 2009;35(9):877-83.

119. Bertolazi AN, Fagondes SC, Hoff LS, Dartora EG, Miozzo IC, de Barba ME, Barreto SS. Validation of the Brazilian Portuguese version of the Pittsburgh Sleep Quality Index. Sleep Med. 2011;12(1):70-5.

120. Wilkinson CP, Ferris FL, Klein RE, Lee PP, Agardh CD, Davis M, Dills D, Kampik A, Pararajasegaram R, Verdaguer JT; Global Diabetic Retinopathy Project Group. Proposed international clinical diabetic retinopathy and diabetic macular edema disease severity scales. Ophthalmology. 2003;110(9):1677-82.

121. Moreira RO, Castro AP, Papelbaum M, Appolinário JC, Ellinger V, Coutinho WF, Zagury L. Tradução para o português e avaliação da confiabilidade de uma escala para diagnóstico da polineuropatia distal diabética. Arq Bras Endocrinol Metab. 2005;49(6):944-50.

122. Boulton AJ. Management of diabetic peripheral neuropathy. Clinical diabetes. 2005;23(1):9-15.

123. Agelink MW, Malessa R, Baumann B, Majewski T, Akila F, Zeit T, Ziegler D. Standardized tests of heart rate variability: normal ranges obtained from 309 healthy humans, and effects of age, gender, and heart rate. Clin Auton Res. 2001;11(2):99-108.

124. Vinik AI, Maser RE, Mitchell BD, Freeman R. Diabetic autonomic neuropathy. Diabetes care. 2003;26(5):1553-79.

125. Levey AS, Stevens LA, Schmid CH, Zhang YL, Castro AF, Feldman HI, Kusek JW, Eggers P, Van Lente F, Greene T, Coresh J; CKD-EPI (Chronic Kidney Disease Epidemiology Collaboration). A new equation to estimate glomerular filtration rate. Ann Intern Med. 2009;150(9):604-12. 
126. Yong Y, Lin H. SHEsis, a powerful software platform for analyses of linkage disequilibrium, haplotype construction, and genetic association at polymorphism loci. Cell Res. 2005;15(2):97.

127. Yau JW, Rogers SL, Kawasaki R, Lamoureux EL, Kowalski JW, Bek T, Chen SJ, Dekker JM, Fletcher A, Grauslund J, Haffner S, Hamman RF, Ikram MK, Kayama T, Klein BE, Klein R, Krishnaiah S, Mayurasakorn K, O'Hare JP, Orchard TJ, Porta M, Rema M, Roy MS, Sharma T, Shaw J, Taylor H, Tielsch JM, Varma R, Wang JJ, Wang N, West S, Xu L, Yasuda M, Zhang X, Mitchell P, Wong TY; Meta-Analysis for Eye Disease (META-EYE) Study Group. Global prevalence and major risk factors of diabetic retinopathy. Diabetes Care. 2012;35(3):556-64.

128. Kanwar M, Chan P-S, Kern TS, Kowluru RA. Oxidative damage in the retinal mitochondria of diabetic mice: possible protection by superoxide dismutase. Invest Ophthalmol Vis Sci. 2007;48(8):3805-11.

129. Haskins K, Bradley B, Powers K, Fadok V, Flores S, Ling X, Pugazhenthi S, Reusch J, Kench J. Oxidative stress in type 1 diabetes. Ann N Y Acad Sci. 2003;1005(1):43-54.

130. Roy S, Kern TS, Song B, Stuebe C. Mechanistic insights into pathological changes in the diabetic retina: implications for targeting diabetic retinopathy. Am $\mathbf{J}$ Pathol. 2017;187(1):9-19.

131. Fu D, Jeremy YY, Yang S, Wu M, Hammad SM, Connell AR, Du M, Chen J, Lyons TJ. Survival or death: a dual role for autophagy in stress-induced pericyte loss in diabetic retinopathy. Diabetologia. 2016;59(10):2251-61.

132. Dehdashtian E, Mehrzadi S, Yousefi B, Hosseinzadeh A, Reiter RJ, Safa M, Ghaznavi H, Naseripour M. Diabetic retinopathy pathogenesis and the ameliorating effects of melatonin; involvement of autophagy, inflammation and oxidative stress. Life Sci. 2018;193:20-33. 
133. Siu AW, Reiter RJ, To $\mathrm{CH}$. The efficacy of vitamin $\mathrm{E}$ and melatonin as antioxidants against lipid peroxidation in rat retinal homogenates. J Pineal Res. 1998;24(4):239-44.

134. Jiang T, Chang Q, Zhao Z, Yan S, Wang L, Cai J, Xu G. Melatonin-mediated cytoprotection against hyperglycemic injury in Müller cells. PLoS One. 2012;7(12):e50661.

135. Melke J, Botros HG, Chaste P, Betancur C, Nygren G, Anckarsäter H, Rastam M, Ståhlberg O, Gillberg IC, Delorme R, Chabane N, Mouren-Simeoni MC, Fauchereau F, Durand CM, Chevalier F, Drouot X, Collet C, Launay JM, Leboyer M, Gillberg C, Bourgeron T. Abnormal melatonin synthesis in autism spectrum disorders. Mol Psychiatry. 2008;13(1):90-8.

136. Etain B, Dumaine A, Bellivier F, Pagan C, Francelle L, Goubran-Botros H, Moreno S, Deshommes J, Moustafa K, Le Dudal K, Mathieu F, Henry C, Kahn JP, Launay JM, Mühleisen TW, Cichon S, Bourgeron T, Leboyer M, Jamain S. Genetic and functional abnormalities of the melatonin biosynthesis pathway in patients with bipolar disorder. Hum Mol Genet. 2012;21(18):4030-7.

137. Rodriguez IR, Mazuruk K, Schoen TJ, Chader GJ. Structural analysis of the human hydroxyindole-O-methyltransferase gene. Presence of two distinct promoters. J Biol Chem. 1994;269(50):31969-77.

138. Halpern B, Mancini MC, Bueno C, Barcelos IP, de Melo ME, Lima MS, Carneiro CG, Sapienza MT, Buchpiguel CA, do Amaral FG, Cipolla-Neto J. Melatonin increases brown adipose tissue volume and activity in patients with melatonin deficiency: a proof-of-concept study. Diabetes. 2019;68(5):947-52.

139. Amstrup AK, Sikjaer T, Pedersen SB, Heickendorff L, Mosekilde L, Rejnmark L. Reduced fat mass and increased lean mass in response to 1 year of melatonin treatment in postmenopausal women: A randomized placebo-controlled trial. Clin Endocrinol (Oxf). 2016;84(3):342-7. 
140. Szewczyk-Golec K, Rajewski P, Gackowski M, Mila-Kierzenkowska C, Wesołowski R, Sutkowy P, Pawłowska M, Woźniak A. Melatonin supplementation lowers oxidative stress and regulates adipokines in obese patients on a calorie-restricted diet. Oxidative medicine and cellular longevity. 2017;2017:8494107.

141. Mostafavi S-A, Akhondzadeh S, Mohammadi MR, Keshtkar A-A, Hosseini S, Eshraghian MR, Motlagh TA, Alipour R, Keshavarz SA. Role of melatonin in body weight: A systematic review and meta-analysis. Curr Pharm Des. 2017;23(23):3445-52.

142. Genario R, Cipolla-Neto J, Bueno AA, Santos HO. Melatonin supplementation in the management of obesity and obesity-associated disorders: A review of physiological mechanisms and clinical applications. Pharmacol Res. 2020;163:105254.

143. Kim T-D, Woo K-C, Cho S, Ha D-C, Jang SK, Kim K-T. Rhythmic control of AANAT translation by hnRNP $\mathrm{Q}$ in circadian melatonin production. Genes Dev. 2007;21(7):797-810.

144. Klein DC, Coon SL, Roseboom PH, Weller J, Bernard M, Gastel JA, Zatz M, Iuvone PM, Rodriguez IR, Bégay V, Falcón J, Cahill GM, Cassone VM, Baler R. The melatonin rhythm-generating enzyme: molecular regulation of serotonin $\mathrm{N}$ acetyltransferase in the pineal gland. Recent Prog Horm Res. 1997;52:307-57; discussion 357-8.

145. Pagan C, Goubran-Botros H, Delorme R, Benabou M, Lemière N, Murray K, Amsellem F, Callebert J, Chaste P, Jamain S, Fauchereau F, Huguet G, Maronde E, Leboyer M, Launay JM, Bourgeron T. Disruption of melatonin synthesis is associated with impaired 14-3-3 and miR-451 levels in patients with autism spectrum disorders. Sci Rep. 2017;7(1):2096.

146. Afsar B, Elsurer Afsar R, Sag AA, Kanbay A, Korkmaz H, Cipolla-Neto J, Covic A, Ortiz A, Kanbay M. Sweet dreams: therapeutic insights, targeting imaging and physiologic evidence linking sleep, melatonin and diabetic nephropathy. Clin Kidney J. 2020;13(4):522-30. 
147. Simko F, Reiter RJ, Pechanova O, Paulis L. Experimental models of melatonindeficient hypertension. Front Biosci(Landmark Ed). 2013;18:616-25.

148. Campos LA, Cipolla-Neto J, Amaral FG, Michelini LC, Bader M, Baltatu OC. The angiotensin-melatonin axis. Int J Hypertens. 2013;2013:521783.

149. Radogna F, Diederich M, Ghibelli L. Melatonin: a pleiotropic molecule regulating inflammation. Biochem Pharmacol. 2010;80(12):1844-52.

150. Dronavalli S, Duka I, Bakris GL. The pathogenesis of diabetic nephropathy. Nat Clin Pract Endocrinol Metab. 2008;4(8):444-52.

151. Cecon E, Oishi A, Jockers R. Melatonin receptors: molecular pharmacology and signalling in the context of system bias. Br J Pharmacol. 2018;175(16):3263-80.

152. Radogna F, Paternoster L, Albertini MC, Cerella C, Accorsi A, Bucchini A, Spadoni G, Diamantini G, Tarzia G, De Nicola M, D'Alessio M, Ghibelli L. Melatonin antagonizes apoptosis via receptor interaction in U937 monocytic cells. J Pineal Res. 2007;43(2):154-62.

153. Ting KN, Blaylock NA, Sugden D, Delagrange P, Scalbert E, Wilson VG. Molecular and pharmacological evidence for MT1 melatonin receptor subtype in the tail artery of juvenile Wistar rats. Br J Pharmacol. 1999;127(4):987-95.

154. Krause DN, Barrios VE, Duckles SP. Melatonin receptors mediate potentiation of contractile responses to adrenergic nerve stimulation in rat caudal artery. Eur $\mathbf{J}$ Pharmacol. 1995;276(3):207-13.

155. Masana MI, Doolen S, Ersahin C, Al-Ghoul WM, Duckles SP, Dubocovich ML, Krause DN. MT2 melatonin receptors are present and functional in rat caudal artery. J Pharmacol Exp Ther. 2002;302(3):1295-302. 
156. Doolen S, Krause DN, Dubocovich ML, Duckles SP. Melatonin mediates two distinct responses in vascular smooth muscle. Eur J Pharmacol. 1998;345(1):67-9.

157. Durvasula RV, Shankland SJ. Activation of a local renin angiotensin system in podocytes by glucose. Am J Physiol Renal Physiol. 2008;294(4):F830-F9.

158. Huang YS, Lu KC, Chao TK, Chen JS, Chen A, Guo CY, Hsieh HY, Shih HM, Sytwu HK, Wu CC. Role of melatonin receptor $1 \mathrm{~A}$ and pituitary homeobox-1 coexpression in protecting tubular epithelial cells in membranous nephropathy. J Pineal Res. 2018;65(1):e12482.

159. Gunn PJ, Middleton B, Davies SK, Revell VL, Skene DJ. Sex differences in the circadian profiles of melatonin and cortisol in plasma and urine matrices under constant routine conditions. Chronobiol Int. 2016;33(1):39-50.

160. Wetterberg L, Bergiannaki JD, Paparrigopoulos T, von Knorring L, Eberhard G, Bratlid T, Yuwiler A. Normative melatonin excretion: a multinational study. Psychoneuroendocrinology. 1999;24(2):209-26.

161. Kostoglou-Athanassiou I, Athanassiou P, Treacher DF, Wheeler MJ, Forsling ML. Neurohypophysial hormone and melatonin secretion over the natural and suppressed menstrual cycle in premenopausal women. Clin Endocrinol (Oxf). 1998;49(2):209-16. 